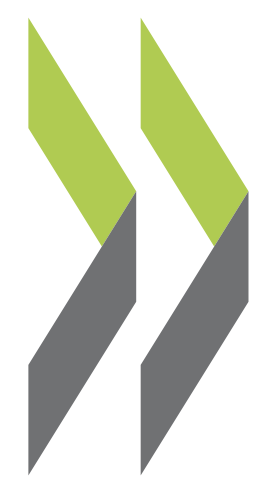

OECD Economics Department Working Papers No. 1331

Fiscal decentralisation and income inequality: Empirical evidence from OECD countries

\section{Sibylle Stossberg,} David Bartolini,

\section{Hansjörg Blöchliger}


Organisation de Coopération et de Développement Économiques

Organisation for Economic Co-operation and Development

23-Sep-2016

ECONOMICS DEPARTMENT

English - Or. English

\section{FISCAL DECENTRALISATION AND INCOME INEQUALITY:}

EMPIRICAL EVIDENCE FROM OECD COUNTRIES

ECONOMICS DEPARTMENT WORKING PAPERS No. 1331

By Sibylle Stossberg, David Bartolini and Hansjörg Blöchliger

OECD Working Papers should not be reported as representing the official views of the OECD or of its member countries. The opinions expressed and arguments employed are those of the author(s).

Authorised for publication by Christian Kastrop, Director, Policy Studies Branch, Economics Department.

All Economics Department Working Papers are available at www.oecd.org/eco/workingpapers

JT03401142

Complete document available on OLIS in its original format

This document and any map included herein are without prejudice to the status of or sovereignty over any territory, to the delimitation of international frontiers and boundaries and to the name of any territory, city or area. 
OECD Working Papers should not be reported as representing the official views of the OECD or of its member countries. The opinions expressed and arguments employed are those of the author(s).

Working Papers describe preliminary results or research in progress by the author(s) and are published to stimulate discussion on a broad range of issues on which the OECD works.

Comments on Working Papers are welcomed, and may be sent to OECD Economics Department, 2 rue André Pascal, 75775 Paris Cedex 16, France, or by e-mail to eco.contact@oecd.org.

All Economics Department Working Papers are available at www.oecd.org/eco/workingpapers.

The statistical data for Israel are supplied by and under the responsibility of the relevant Israeli authorities. The use of such data by the OECD is without prejudice to the status of the Golan Heights, East Jerusalem and Israeli settlements in the West Bank under the terms of international law.

Latvia was not an OECD Member at the time of preparation of this publication. Accordingly, Latvia does not appear in the list of OECD Members and is not included in the zone aggregates.

\section{(c) OECD (2016)}

You can copy, download or print OECD content for your own use, and you can include excerpts from OECD publications, databases and multimedia products in your own documents, presentations, blogs, websites and teaching materials, provided that suitable acknowledgment of OECD as source and copyright owner is given. All requests for commercial use and translation rights should be submitted to rights@oecd.org 


\section{Abstract \\ Fiscal decentralisation and income inequality: Empirical evidence from OECD countries}

This paper investigates the relationship between fiscal decentralisation and economy-wide disposable income inequality. Drawing on a dataset of up to 20 OECD countries over a period from 1996 to 2011, a regression analysis is performed, relating several indicators of national income inequality and a wide array of fiscal decentralisation indicators. The results indicate a weak, inequality-reducing relationship between decentralisation and income inequality, as measured by the Gini coefficient, but the effect is rather small and unstable across specifications. Fine-graining the analysis by using income percentile ratios, in turn, produces more significant and stable results. It shows that the effects of fiscal decentralisation are not the same along the income distribution. While decentralisation tends to be associated with a reduction in income inequality between high incomes and the median, it is linked to a divergence of low income groups from the median, notably via sub-central tax autonomy. Transfers between levels of government also tend to increase the gap between lower and middle incomes. Interpreting these effects jointly, it seems that mainly middle income earners benefit from fiscal decentralisation. Finally, some insights on decentralisation and regional income inequality are presented. At first sight, fiscal decentralisation does not seem to be associated with income sorting in large jurisdictions, but a more fine-grained analysis is required to answer this question.

Keywords: Fiscal decentralisation, disposable income inequality, intergovernmental transfers, tax autonomy, income percentile ratios, regional inequality

JEL codes: D63; H10; H70; H71; H75; I38

$$
* * * * *
$$

\section{Résumé}

\section{Décentralisation budgétaire et inégalités de revenu : données empiriques relatives aux pays de l'OCDE}

Nous étudions dans ce document la relation entre la décentralisation budgétaire et les inégalités de revenu disponible à l'échelle d'une économie. À partir d'un ensemble de données concernant jusqu'à 20 pays de l'OCDE au cours de la période de 1996 à 2011, nous réalisons une analyse de régression mettant en relation plusieurs indicateurs d'inégalités de revenu nationales et un large éventail d'indicateurs de décentralisation budgétaire. Les résultats obtenus font ressortir une faible corrélation inverse entre la décentralisation et les inégalités de revenu, mesurées par le coefficient de Gini, mais cet effet est relativement modeste et instable d'une spécification à l'autre. Lorsqu'on affine l'analyse en utilisant des rapports interquantiles de revenu, on obtient des résultats plus significatifs et stables. Ils montrent que les effets de la décentralisation budgétaire ne sont pas les mêmes suivant les parties de la distribution des revenus examinées. Alors que la décentralisation tend à aller de pair avec une réduction des inégalités de revenu entre les catégories à revenu élevé et la médiane, elle s'accompagne d'une divergence des groupes à faible revenu par rapport à la médiane, notamment liée à l'autonomie fiscale des administrations infranationales. Les transferts entre niveaux d'administration tendent également à creuser l'écart entre les catégories à faible revenu et à revenu moyen. Lorsqu'on interprète ces effets dans leur globalité, il semble que ce sont principalement les personnes aux revenus d'activité moyens qui tirent parti de la décentralisation budgétaire. Enfin, nous présentons certains éléments de réflexion sur la décentralisation et les inégalités de revenu régionales. À première vue, la décentralisation budgétaire ne semble pas être associée à un regroupement par niveau de revenu dans les grandes juridictions, mais une analyse plus fine s'impose sur ce point.

Mots-clés : décentralisation budgétaire, inégalités de revenu disponible, transferts entre niveaux d'administration, autonomie fiscale, rapports interquantiles de revenu, inégalités régionales

Classification JEL : D63 ; H10 ; H70 ; H71 ; H75 ; I38 


\section{TABLE OF CONTENTS}

\section{FISCAL DECENTRALISATION AND INCOME INEQUALITY: EMPIRICAL EVIDENCE FROM

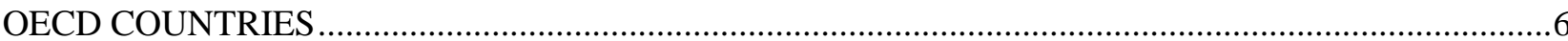

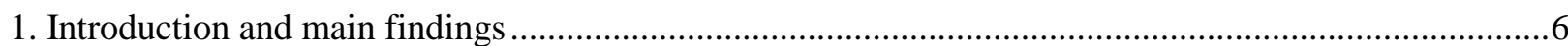

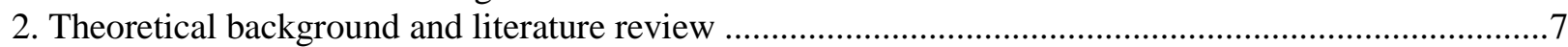

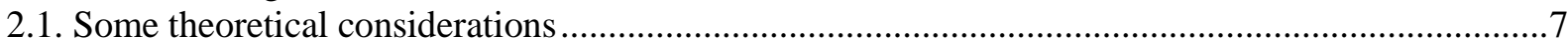

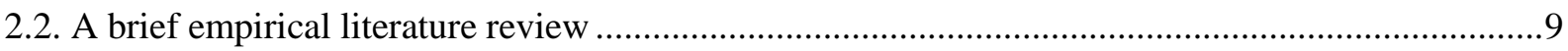

3. The empirical link between decentralisation and national income inequality .....................................10

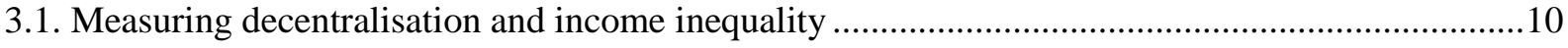

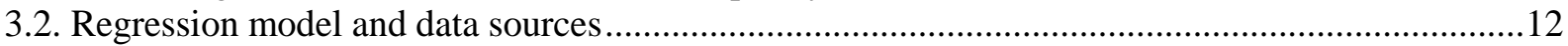

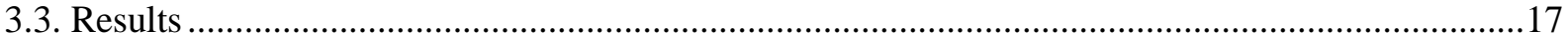

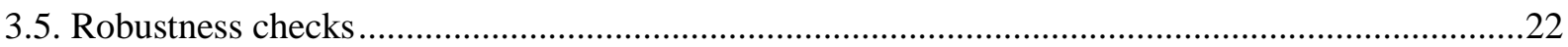

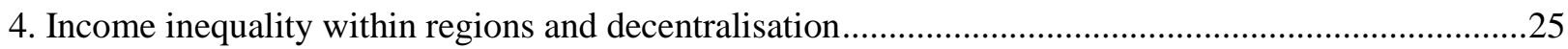

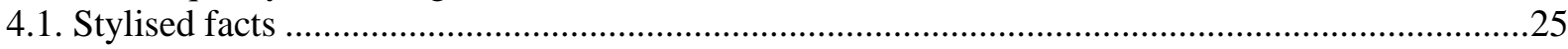

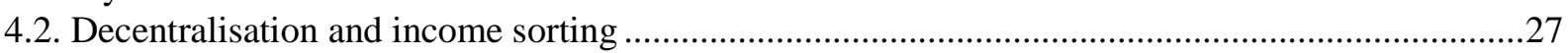

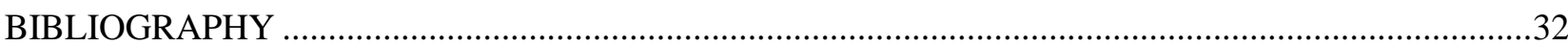

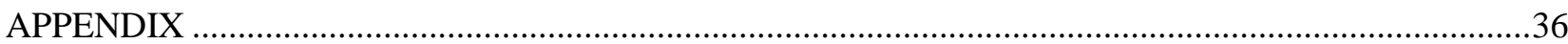

\section{Tables}

1. Correlation matrix of the general decentralisation indicators .....................................................14

2. Fixed effects Gini regression results: General fiscal decentralisation indicators..........................18

3. Fixed effects Gini regression results: Policy-area-specific fiscal decentralisation indicators .......19

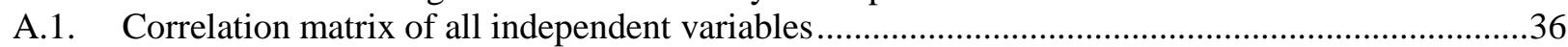

A.2. Fixed effects percentile ratio regressions: Revenue decentralisation.........................................37

A.3. Fixed effects percentile ratio regressions: Tax decentralisation ..................................................38

A.4. Fixed effects percentile ratio regressions: Spending decentralisation..........................................39

A.5. Fixed effects percentile ratio regressions: Tax autonomy .......................................................... 40

A.6. Fixed effects percentile ratio regressions: Summary of decentralisation coefficient results .........41

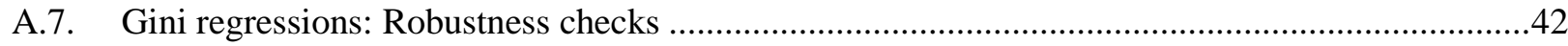

A.8. Percentile ratio regressions: Summary table for robustness checks ..........................................43

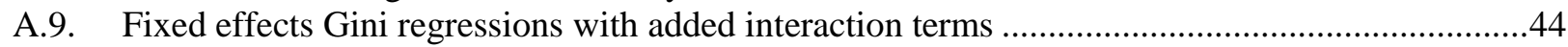

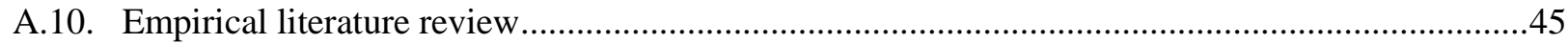

\section{Figures}

1. Revenue and spending decentralisation in OECD countries..................................................11

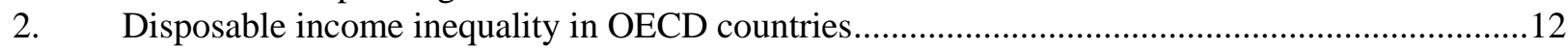

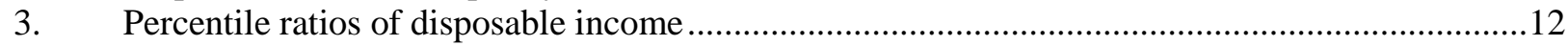

4. Fixed effects percentile ratio regression results: General decentralisation indicators ...................20

5. Fixed effects percentile ratio regression results: Policy-area-specific decentralisation indicators. 
6. Robustness checks for the Gini regressions: Selected fiscal decentralisation coefficients .23

7. Robustness checks for the percentile ratio regressions: Selected fiscal decentralisation

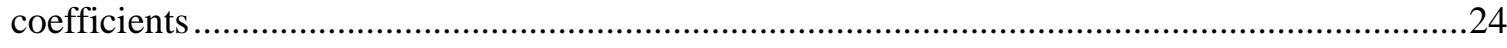

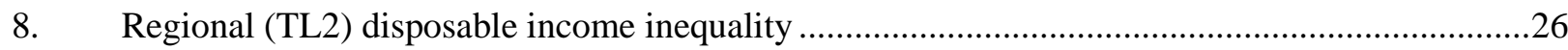

9. Range of regional (TL2-level) Gini coefficients of disposable income and decentralisation........27

10. Regional (TL2) Gini coefficients of disposable income by country ..........................................28

11. The difference between national and regional median Ginis versus tax autonomy ......................29

12. Coefficient of variation of mean disposable income across TL2 regions, by quintile ...................30

13. Quintile income variation across TL2 regions and decentralisation indicators .............................31

\section{Boxes}

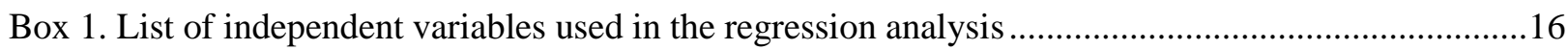

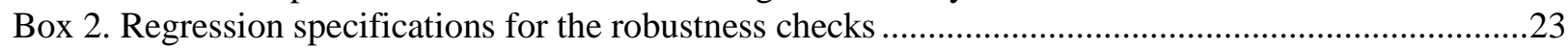




\title{
FISCAL DECENTRALISATION AND INCOME INEQUALITY: EMPIRICAL EVIDENCE FROM OECD COUNTRIES
}

\author{
By Sibylle Stossberg, David Bartolini and Hansjörg Blöchliger ${ }^{1}$
}

\section{Introduction and main findings}

1. Household income inequality has risen in many OECD countries over the last two decades, and has become a growing policy concern. Within the same time frame, the fiscal authority of sub-central governments (SCGs) has increased, raising their relevance in shaping national policy outcomes. The degree of decentralisation in a country is often a product of long-term historical developments rather than a decision based on specific fiscal or social policy goals. However, fiscal decentralisation can affect social outcomes through multiple channels. Theoretical considerations do not provide a clear sign for the relationship between fiscal decentralisation and income inequality. On the one hand, a high degree of fiscal decentralisation reduces the central government's capacity to establish comparable living conditions across regions (Tselios et al., 2012). On the other hand, fiscal decentralisation brings policies closer to local needs and preferences (Oates, 1972), increases political ownership and may therefore provide more effective and equitable policy outcomes.

2. The aim of this paper is to empirically investigate the relationship between fiscal decentralisation and national income inequality. The analysis focuses on disposable rather than market income inequality because market income inequality mainly depends on the functioning of labour markets and how they are affected by globalisation and technological change rather than on intergovernmental fiscal frameworks. Drawing on a dataset of up to 20 OECD countries over a period from 1996 to 2011, a regression analysis is performed, relating several indicators of national income inequality with a wide array of fiscal decentralisation indicators. Finally, some insights on the link between decentralisation and income inequality within regions are presented.

3. The key findings are the following:

- The empirical work focuses first on national income inequality as measured by the Gini coefficient, which is also done in virtually all existing empirical studies. Spending and revenue decentralisation tend to reduce disposable income inequality, but the impact is rather weak in magnitude and significance. An increase in spending decentralisation by ten percentage points

1. Hansjörg Blöchliger and David Bartolini are in the Economics Department and the Public Governance and Territorial Development Directorate of the OECD and Sibylle Stossberg is with the German Federal Ministry of Finance (Bundesministerium der Finanzen). At the time of writing this paper, David Bartolini was with the Economics Department and Sibylle Stossberg was on leave from the Ministry. The authors are grateful to Monica Brezzi, Jose Enrique Garcilazo, Luiz de Mello and Joaquim Oliveira-Martins (Public Governance and Territorial Development Directorate), Peter Hoeller, Christian Kastrop, Jean-Luc Schneider and Eckhard Wurzel (Economics Department) as well as the delegates of the OECD Fiscal Network for comments on earlier drafts. Special thanks go to Celia Rutkoski for assistance in preparing this document. This paper is part of an OECD project on fiscal decentralisation and inequality. The other papers include an OECD Economic Policy Paper (Blöchliger, Bartolini and Stossberg, 2016) that summarises the whole project, a working paper on fiscal decentralisation and regional disparities (Bartolini, Stossberg and Blöchliger, 2016) and a working paper on the evolution of regional disparities (Arnold and Blöchliger, 2016). 
leads to a reduction of the (between 0 and 1 ranging) Gini coefficient of roughly 0.01 . Revenue decentralisation has a similarly sized effect.

- The effects of spending and revenue decentralisation on the Gini coefficient are not uniform across policy areas. While the decentralisation of economic affairs spending shows a small inequality-decreasing impact, the decentralisation of education spending shows the reverse. Other spending areas - health and social protection spending - show no effect. Property taxes are inequality-increasing, while income tax decentralisation shows no effect.

- Fine-graining the analysis by employing income percentile ratios instead of the Gini coefficient produces clearer and more significant results. It shows that fiscal decentralisation has different impacts for different parts of the income distribution. Spending, revenue, tax decentralisation, and in particular sub-central tax autonomy are associated with an amplified gap between low income groups up to the third decile and the median. At the same time, fiscal decentralisation is linked to a decrease in the gap between high incomes and the median. This is especially the case on the expenditure side and through social protection spending decentralisation.

- Regional transfers across levels of government have an inequality-increasing effect on the gap between lower and middle incomes. This finding highlights the drawbacks linked to an unbalanced decentralisation of the spending and revenue side.

- The regressions using income percentile ratios as the dependent variable - as opposed to the Gini regressions - produce stable results for the fiscal decentralisation variables in robustness checks which correct for potential endogeneity, serial correlation and cross-sectional dependence. This finding underlines the importance of going beyond a summary indicator such as the Gini coefficient when aiming to capture the full effects of decentralisation on the income distribution.

- A descriptive analysis of inequality patterns within regions shows no indications of regional income sorting following fiscal decentralisation at first sight. In order to shed more light on this question, a more thorough analysis at a lower territorial level is required once more regional data become available.

4. The remainder of the paper is structured as follows: Section 2 provides a short theoretical background and a review of the relevant empirical literature. In section 3, the effects of fiscal decentralisation on national disposable income inequality are analysed empirically. Section 4 presents some results on the relationship between fiscal decentralisation and regional income inequality.

\section{Theoretical background and literature review}

\subsection{Some theoretical considerations}

5. Theoretical considerations do not provide a clear indication on the relationship between fiscal decentralisation and disposable income inequality, as there are some direct, but also many indirect factors that shape the income distribution (Sacchi and Salotti, 2014). In the following, theoretical arguments will be outlined by decentralisation type.

6. Decentralisation on the (tax) revenue side may have a direct impact on income inequality, if it causes a change in the national composition of revenue instruments. Standard revenue categories of subcentral governments (SCGs) tend to be less progressive or can even be regressive in nature, such as property taxes and user fees. If decentralisation leads to a heavier reliance on these instruments, the overall progressiveness of the tax system might be reduced, leading to higher income inequality (Sepulveda and Martinez-Vazquez, 2011). By contrast, revenue decentralisation may reduce income inequality by 
improving tax collection, especially of the self-employed, therefore increasing redistribution. If revenues are known to stay in the region, there might be stronger incentives both for citizens to declare their taxable income fully within the region and for local authorities to control and enforce tax laws (Torgler, 2007; Güth et al., 2005).

7. Further factors come into play when sub-central governments do not just receive a certain share of tax revenue, but also have policy autonomy over the design and level of taxation. How tax autonomy affects income inequality depends on the assumptions made about interregional taxpayer mobility. If one assumes low mobility costs for households and a strong responsiveness to changes in taxation levels, then the capability of a region to carry out income redistribution via tax policies is limited (Oates, 1972; Prud'homme, 1995). Well-off households could simply move to another jurisdiction where taxation levels for high incomes are lower. If a "race to the tax bottom" across regions occurs, too little redistribution takes place, driving up disposable income inequality overall (Sepulveda and Martinez-Vazquez, 2011). Hodler and Schmidheiny (2006) show in a multi-community model that when communities can set the level of taxation in an overall progressive tax schedule, fiscal decentralisation reduces the progressivity of the schedule. The result is caused by income sorting. Tax autonomy under the assumption of high mobility might also affect the distribution of market income. Business-friendly taxation in certain regional hot spots can lead to business agglomerations, leading to higher productivity and therefore higher income differentials with respect to non-agglomeration areas. However, inter-jurisdictional mobility due to subcentral tax competition tends to be limited. For households, taxation is not the only factor when choosing a location to settle. Their decision also strongly depends on labour market opportunities and the bundle of public goods offered within a region (Blöchliger and Pinero Campos, 2011). If the extent of taxpayer mobility is low, sub-central governments might be more efficient than the central government at tackling inequality via redistributive taxes. This could be the case under the general assumption that sub-central governments can better adjust to local needs and preferences (Oates, 1972; Tselios et al., 2012).

8. With regards to decentralisation on the spending side, similar arguments for efficiency gains can be made. Local policy-makers have an information advantage on local circumstances and may thus be able to better tailor spending policies to reduce income inequality (Sacchi and Salotti, 2014; Le Galès, 2002; Brenner, 2004). At the same time however, the influence of local lobby groups might be stronger when spending takes place at the local level (Governatori and Yim, 2012). This might undermine attaining distributional objectives. The impact of spending decentralisation on inequality is also contingent upon the quality of local institutions. If sub-central government administrations might be less able to attract skilled employees than the central government (Prud'homme, 1995), and if corruption at the local level is high, inequality might be tackled less effectively. Finally, spending decentralisation might affect the overall public expenditure composition (González Alegre, 2010; Sepulveda and Martinez-Vazquez, 2011), which in turn can have an effect on income inequality. For instance, Keen and Marchand (1997) argue that in the absence of coordination and under certain conditions, inter-jurisdictional tax competition may lead to an under-provision of public consumption goods, while it may lead to an oversupply of productivityenhancing public inputs to attract mobile capital. Drawing a link to income inequality, middle income earners might benefit from these changes in the expenditure composition if they lead to higher growth, while lower income groups in particular might incur losses from a reduction in public consumption goods.

9. Assumptions on inter-jurisdictional mobility matter in particular for social protection spending. Given that this expenditure category is directly redistributive, a significant sub-central spending share might create adverse effects when mobility is high. Low income households would have a strong incentive to move to regions where social transfers and benefits in kind are higher, again leading to income sorting. For this reason, the traditional fiscal federalism literature argues that redistribution should be carried out at the national level (Oates, 1972; Brown and Oates, 1987; Musgrave, 1959). However, in many countries, the entitlement to social cash benefits is fixed by national laws, in which case regions are merely responsible for paying these benefits. Decentralisation might cause a variation in the quality and 
accessibility of public services, while at the same time there is less room for manoeuvre for central governments to reduce regional differences (Tselios et al., 2012). If fiscal equalisation is weak or absent, regions with many transfer-dependent households might lack sufficient fiscal space for other social programmes or for business-friendly policies (Prud'homme, 1995). This again might have an impact on income inequality. The decentralisation of education spending might be harmful for overall income inequality if it leads to unequal spending levels across regions and therefore exacerbates regional education quality differences, which feed into higher earnings differentials later on. Education spending decentralisation could, however, also have a positive impact given that education spending is higher in decentralised environments (Fredriksen, 2013).

10. Possible effects of different forms of decentralisation have been discussed separately so far, but the various types and their effects are often interconnected. A higher degree of tax decentralisation often correlates with higher tax autonomy; more spending decentralisation often comes with a higher decentralisation of education spending. High expenditure decentralisation in combination with low revenue decentralisation naturally comes with higher intergovernmental transfers.

11. Sepulveda and Martinez-Vazquez (2011) list a number of channels through which fiscal decentralisation might affect income inequality indirectly. These are economic growth, macroeconomic stability, the convergence of regions, government size and the level of institutional development. For example, several studies establish the link that in decentralised countries, sub-central governments tend to implement pro-growth policies, fostering business and household mobility and thereby convergence of household incomes (McKinnon, 1997; Qian and Weingast, 1997; Zodrow and Mieszkowski, 1986). How exactly these indirect channels play out is, however, hard to predict, as the outcome often depends on country-specific institutional and economic settings.

\subsection{A brief empirical literature review}

12. A summary table of the empirical literature on the relationship between fiscal decentralisation and income inequality can be found in Table A.10. The overview shows that the empirical findings are mixed. When comparing the results, one should carefully distinguish which inequality and decentralisation concepts are used, as well as the time span, the country sample and the empirical approach. What is common to almost all studies is that they use a summary indicator to measure inequality, notably the Gini coefficient. The effects of decentralisation on various income deciles have so far not been looked at thoroughly.

13. Most studies focus on the link between decentralisation and disposable income inequality at the national level. These studies tend to find an income-inequality-reducing effect of fiscal decentralisation once certain development criteria, such as a sufficient public sector size and well-functioning institutions, are met: Neyapti (2006) looks at the effect of revenue decentralisation on the disposable income Gini coefficients in 37 countries over three decades. She finds that revenue decentralisation has an equalising effect on the income distribution when it is interacted with good governance. Sepulveda and MartinezVazquez (2011) show in their analysis of developed and developing countries from 1971 to 2000 that expenditure decentralisation increases income inequality for countries with a small government size, but has an inequality-reducing effect when the government size is $20 \%$ of GDP or more. Additionally, they find that expenditure decentralisation leads to worse poverty outcomes in developing countries. Goerl and Seiferling (2014) also look at a mix of developed and developing countries from 1980 onwards. They also find that expenditure decentralisation interacted with government size reduces inequality. The authors also look at the impact of expenditure decentralisation in the policy areas social protection, health, education, and redistributive expenditure. These show no significant relationship with income inequality, from which the authors conclude that expenditure decentralisation should be comprehensive. On the other hand, they show that sub-national dependency on transfers from other levels of government raises inequality. 
14. Beramendi (2003) uses a dataset of 15 OECD countries from 1980 to 1997 and finds indications that decentralisation does not exogenously affect disposable income inequality, but that it is endogenous to the internal structure of inequality within regions. He also shows that the higher the degree of decentralisation, the larger are the differences between regions in terms of income and labour market structures, even after controlling for endogeneity. He therefore concludes that "decentralization has distributive consequences that are contingent upon the existing structure of inequality. Because of such contingency, actors anticipate the distributive effects of different institutional designs and, thereby, inequality becomes a determinant of the institutional choice."

15. Empirical analyses on the effect of decentralisation on national market income inequality are less frequent. Sacchi and Salotti (2014) use the Gini of market household income as their dependent variable for a sample of 23 OECD countries from 1971 to 2000. They take into account various indicators of revenue and expenditure decentralisation. The authors find an inequality-increasing effect of tax decentralisation on market income inequality, while no significant effects of expenditure decentralisation were detected.

16. Another set of studies are based on regional inequality data, and are limited to one country. For instance, Morelli and Seaman (2007) investigate the effects of fiscal devolution in the United Kingdom, particularly of Scotland and Wales, on income inequality over a period from 1991 to 2003. They find no discernible, statistically significant impact. Savitri (2012) finds a positive relationship between revenue decentralisation and income inequality in Indonesian provinces.

17. Tselios et al. (2012) work with a combination of regional and national data. They look at 102 Western European regions from 1995 to 2000, using the Theil index of net personal income as an inequality measure. They find an inequality-reducing relationship of fiscal decentralisation within a region. They also show that further decentralisation is linked with a smaller decrease in inequality, the higher the regional income.

\section{The empirical link between decentralisation and national income inequality}

\subsection{Measuring decentralisation and income inequality}

\section{Fiscal decentralisation}

18. The degree of decentralisation varies significantly across OECD countries. Spending is by far more decentralised than revenue, with an average sub-central share of 32\% in 2011, ranging from $6 \%$ in Greece to 68\% in Canada. From 1995 to 2011, the OECD average of spending decentralisation increased by 2 percentage points. For most countries, changes in decentralisation levels occurred relatively smoothly over time. Notable exceptions are a steep decline in spending decentralisation in Ireland in the mid-2000s and a steep increase in the Slovak Republic from the early 2000s onwards. 
Figure 1. Revenue and spending decentralisation in OECD countries

2011

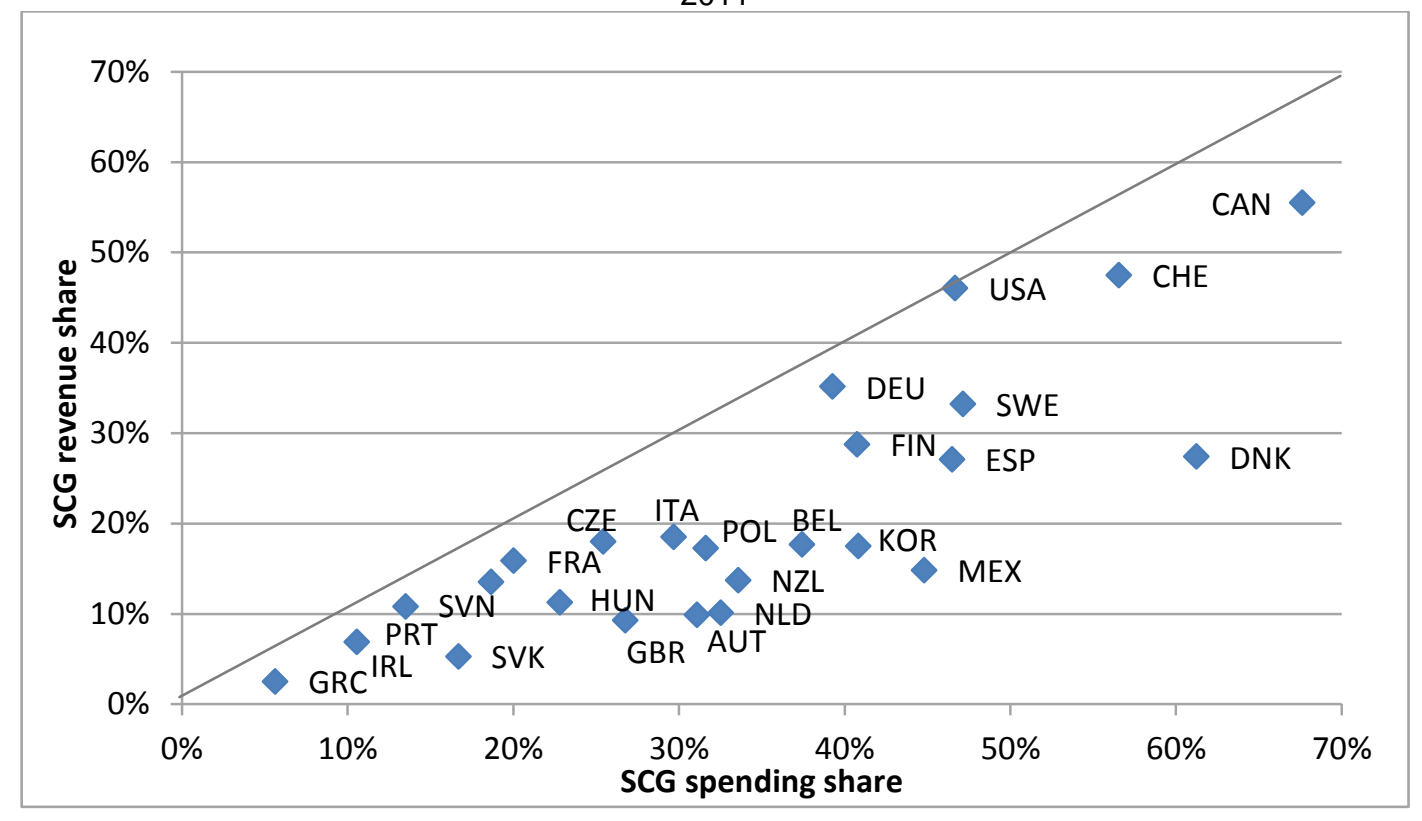

Source: OECD Fiscal Decentralisation Database, www.oecd.org/tax/federalism/oecdfiscaldecentralisationdatabase.htm.

19. By contrast, revenues are much less decentralised. Sub-central revenue shares averaged $19 \%$ in 2011, ranging from 3\% in Greece to 56\% in Canada. While the OECD average in 1995 was approximately at the same level as 2011, some countries experienced major changes. For example, revenue decentralisation in Spain and Italy increased by up to 10 percentage points. In Denmark and Hungary, the sub-central revenue share dropped sharply in the early and mid-2000s. Given that revenue decentralisation has not kept up with spending decentralisation on average, the vertical fiscal imbalance has increased. This implies that a higher share of sub-central spending is financed by intergovernmental transfers instead of own revenues.

20. Tax revenues are slightly less decentralised than total revenues. The sub-central tax revenue share averaged 15\% across the OECD in 2011. What also matters is the degree of autonomy that SCGs have over the tax revenues they receive. In 2011, SCGs had some base or rate-setting autonomy over roughly three quarters of the tax revenues they received. Sub-central tax autonomy slightly increased from 1995 to 2011 (Blöchliger and Nettley, 2015).

\section{Income inequality}

21. Around 2011, the national Gini coefficients of disposable income ranged between 0.25 and 0.5 . Disposable household income inequality was lowest in the Nordic and some Eastern European countries, and highest in Chile, followed by Mexico, Turkey, the United States and Israel. Figure 2 shows that disposable income inequality increased in most countries (where data are available) from 1995 to 2005. The development from 2005 to 2011 was more diverse: While inequality increased in 11 countries, it decreased in 21 countries. 
Figure 2. Disposable income inequality in OECD countries

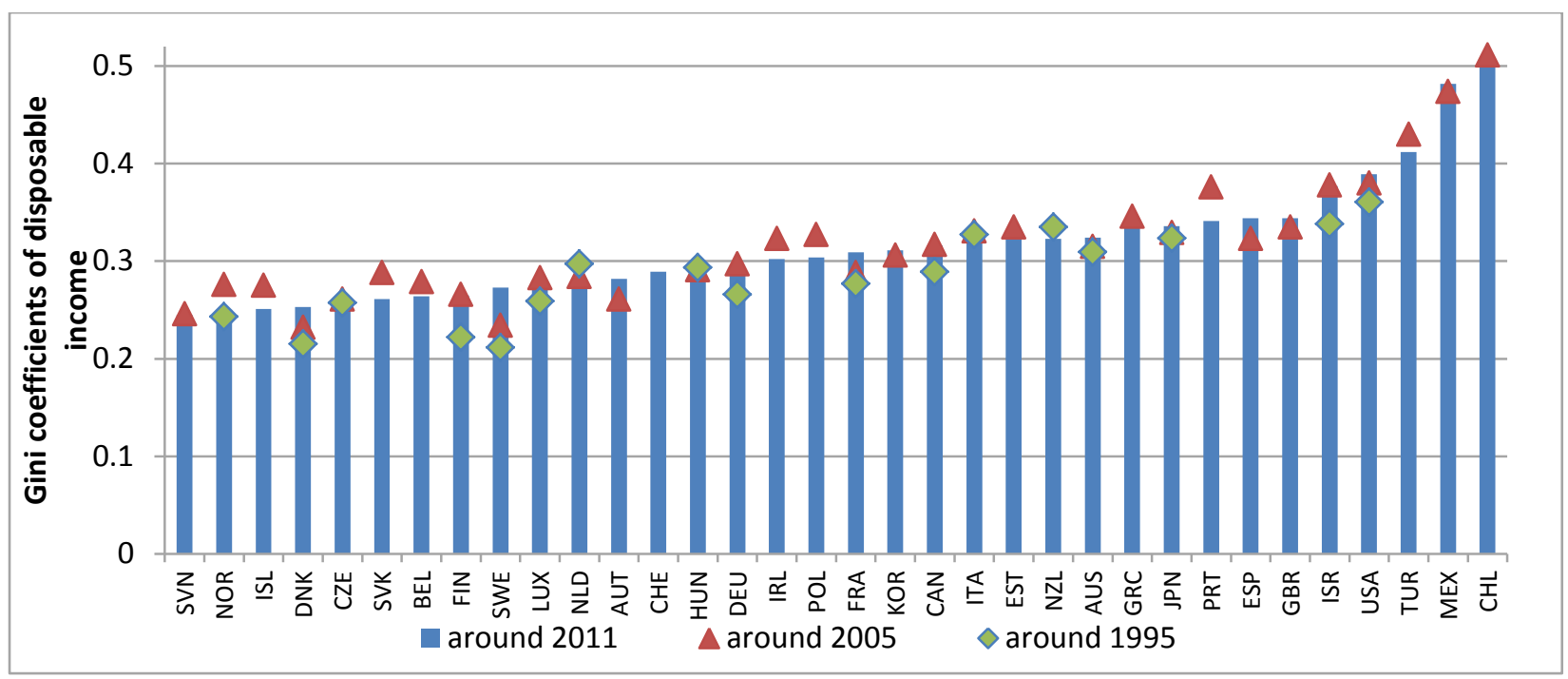

Note: The Gini coefficient ranges from 0 (perfect equality) to 1 (perfect inequality) and reflects individual, household-equivalised income.

Source: OECD "Income distribution", OECD Social and Welfare Statistics (database), DOI: http://dx.doi.org/10.1787/data-00654-en.

22. Percentile ratios measure the gap between different positions along the income distribution. Like the Gini coefficient, these ratios also show much variation across OECD countries. Around 2011, the P50/P10 ratio averaged 2.1 across countries. This implies that the median disposable income $\left(50^{\text {th }}\right.$ percentile) was on average 2.1 times higher than the upper bound of the lowest income decile ( $10^{\text {th }}$ percentile). The P50/P10 ratio varied from 1.7 in Iceland to 3.2 in Mexico. The gap between high and middle incomes (P90/P50 ratio) tended to be slightly lower in most OECD countries, with 2.0 on average.

Figure 3. Percentile ratios of disposable income

Around 2011

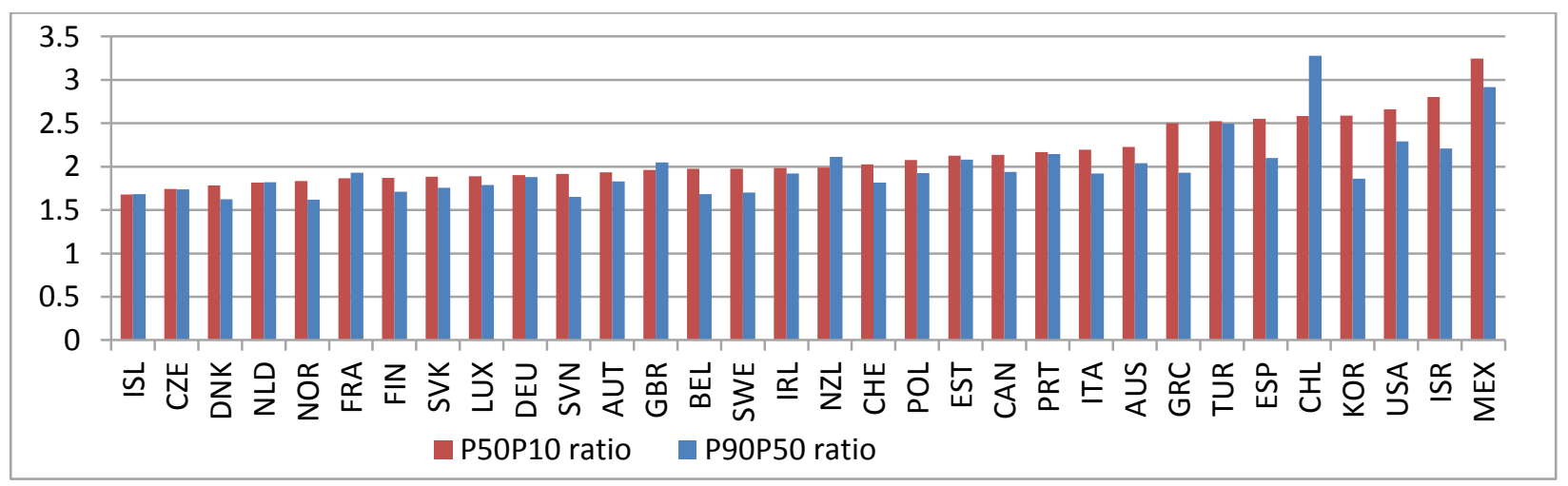

Note: P10 signifies the upper bound of the poorest $10 \%\left(10^{\text {th }}\right.$ percentile). P90 signifies the lower bound of richest $10 \%$ $\left(90^{\text {th }}\right.$ percentile). P50 stands for the median $\left(50^{\text {th }}\right.$ percentile). The percentile ratios are based on individual, household-equivalised income.

Source: OECD "Income distribution", OECD Social and Welfare Statistics (database), DOI: http://dx.doi.org/10.1787/data-00654-en. 


\subsection{Regression model and data sources}

23. The empirical analysis in this section is carried out at the country level, and covers an unbalanced panel of up to 26 OECD countries over a period from 1996 to 2011. The regression model is estimated using country fixed effects, and has the following linear specification (where subscript $i$ indicates the country and subscript $t$ the year):

$$
\text { Disp_inequality }_{i t}=c+\beta_{1} D E C_{i t}+\beta_{2} R S_{i t}+\beta_{3} X_{i t}+\varepsilon_{i t}
$$

24. Disp_inequality ${ }_{i t}$ stands for disposable income inequality at the national level. ${ }^{2}$ Two different types of inequality indicators are used as the dependent variable:

- For a first set of regressions, the Gini coefficient of disposable income is employed, as this indicator is usually used in the empirical literature.

- One of the drawbacks of a summary indicator like the Gini coefficient is that it does not contain information about different sections of the income distribution. An increase or decrease of the Gini coefficient might stem from changes in the upper, middle or lower part of the income distribution, but it is not possible to locate where (Hoeller et al., 2012). Given the many channels through which decentralisation may affect income inequality, it seems likely that it has varying positive or negative effects for different parts of the income distribution. Therefore, in a second set of regressions, various income percentile ratios are sequentially introduced as the dependent variable. Percentile ratios measure the gaps between different points on the income distribution. For instance, the P90/P50 ratio expresses the ratio of the lower bound of the richest $10 \%$ of disposable incomes $\left(90^{\text {th }}\right.$ percentile) to the median disposable income (50 ${ }^{\text {th }}$ percentile). It therefore indicates the gap between an income ranked comparatively high in the distribution and the median.

25. Assuming that the effect of fiscal decentralisation on income inequality likely does not maintain the same sign along the income distribution, it can be expected that the set of regressions with income percentile ratios will produce clearer and more stable results for the decentralisation indicators than the Gini regressions.

26. Finally, the analysis focuses on disposable rather than market income inequality as it captures redistributive policies directly. Moreover, as pointed out above, fiscal decentralisation is likely to have a stronger effect on disposable, rather than market income, which is mainly shaped by the functioning of labour markets and globalisation. In the robustness section, however, a check on the influence of fiscal decentralisation on market income inequality is carried out.

27. $D E C_{i t}$ is a set of fiscal decentralisation indicators that captures different dimensions of fiscal decentralisation. Included are four general decentralisation indicators (revenue, tax and spending decentralisation, tax autonomy) and a range of policy-area-specific decentralisation indicators. ${ }^{3}$ Because of multicollinearity (Table 1), the indicators are used sequentially in separate regressions. An overview of the individual decentralisation indicators as well as all other dependent variables and their sources is provided in Box 1.

2. Income distribution indicators refer to persons, who are ranked by household-equivalised disposable income. Incomes are adjusted by the square root of the household size. For instance, the income of a household with four persons would be divided by two (OECD, 2012).

3. For further information on fiscal decentralisation indicators, see Blöchliger et al. (2013). 
Table 1. Correlation matrix of the general decentralisation indicators

\begin{tabular}{lccc}
\hline & $\begin{array}{c}\text { Revenue } \\
\text { decentralisation }\end{array}$ & $\begin{array}{c}\text { Tax } \\
\text { decentralisation }\end{array}$ & $\begin{array}{c}\text { Spending } \\
\text { decentralisation }\end{array}$ \\
\hline Revenue decentralisation & 1 & & \\
autonomy
\end{tabular}

Note: The values were calculated for the fixed effects regression sample of 20 OECD countries.

Source: OECD Fiscal Decentralisation Database, www.oecd.org/tax/federalism/oecdfiscaldecentralisationdatabase.htm; Secretariat calculations.

28. $R S_{i t}$ is a vector of variables that quantify the overall size of national redistribution systems with respect to GDP. Two types of systems are distinguished, territorial redistribution and individual redistribution. The aim is to capture separately, how much countries spend on redistribution between regions, on the one hand, and on redistribution between individuals, on the other hand.

- Territorial redistribution is quantified by a variable measuring intergovernmental transfer expenditure at all levels of government as a ratio of GDP. Only vertical transfers are taken into account, i.e. transfers from higher to lower levels of government or vice versa. An exception is made for Germany and Switzerland, where horizontal equalisation systems are in place, which are therefore added.

- To account for individual redistribution, three variables are included simultaneously in the regressions: The size of the individual transfer system is captured by general government expenditure on individual cash benefits in relation to GDP. The tax side is captured by general government revenue from personal taxes in per cent of GDP, as well as by an index measuring the progressivity of household taxes, the Kakwani index.

- In practice, territorial and individual systems are closely linked and it is not possible to separate them in a clean way. It is, for instance, possible that a share of regional transfers received by an SCG is passed on to individuals in the form of cash benefits. In this case, it would count towards both regional redistribution and individual redistribution, making the overall expenditure seem much larger when compared with other countries where the two transfer systems do not overlap. For this reason, a consolidation across systems was carried out. The size of the intergovernmental transfer expenditure variable was reduced by the amount of sub-central individual cash benefit expenditure likely not financed independently by SCGs. This amount was approximated by multiplying sub-central cash benefit expenditure by the vertical fiscal imbalance, i.e. the percentage of overall sub-central spending financed by intergovernmental transfer revenue.

29. Finally, $X_{i t}$ is a set of control variables that are expected to have an impact on the distribution of market income. ${ }^{4}$ Included are variables that control for labour market characteristics, which are the unemployment rate, trade union density and employment protection legislation, as well as measures for human capital, urbanisation, openness to trade and the effectiveness of government. Higher unemployment is assumed to increase income inequality as it implies low income for those affected. The effects of higher trade union density and employment protection legislation are ambiguous. On the one hand, they might lead to less labour income inequality of those employed. On the other hand, they might impede access to the labour market for those seeking to enter (Koske et al., 2012). Education and trade openness have also

4. Kierzenkowski and Koske (2012) and OECD (2011) provide a comprehensive review of the drivers of labour income inequality. 
shown ambiguous effects in the empirical literature (ibid.). Higher government effectiveness is assumed to have an inequality-reducing impact as policy will be implemented in an effective way.

30. Some diagnostics were carried out to refine the specification and to test its validity:

- The Hausman test suggests the use of country fixed effects over random effects for all regressions.

- Due to an indication of heteroskedasticity in all fixed effects regressions and concerns of serial correlation of the error terms in some, robust, country-clustered standard errors are used.

- Time fixed effects are jointly significant in many of the regressions. They are therefore uniformly applied in all fixed effects regressions. The robustness section contains a specification without time-fixed effects.

- For the set of independent variables, multicollinearity concerns can be ruled out. The overall variance inflation factor (VIF) lies at 2.9 on average across all Gini regressions, and for none of the regressors does the tolerance level $\left(1-R^{2}\right)$ fall below 0.1. Table A.1. displays bivariate correlations for all independent variables used in the regressions. 


\section{Box 1. List of independent variables used in the regression analysis}

Fiscal decentralisation indicators $\left(D E C_{i t}\right)$

General indicators:

- Revenue decentralisation: The ratio of sub-central to general government revenue (OECD Fiscal Decentralisation Database).

- Tax decentralisation: The ratio of sub-central own tax revenue to general government tax revenue (OECD Fiscal Decentralisation Database).

- Spending decentralisation: The ratio of sub-central to general government spending (OECD Fiscal Decentralisation Database).

- Tax autonomy: The ratio of taxes over which SCGs have some base or rate-setting autonomy to general government tax revenue. Observations are only available for 1995, 2002, 2005, 2008 and 2011. A time series was generated by interpolation (OECD Fiscal Decentralisation Database).

Policy-area-specific indicators:

- Education / social protection / health / economic affairs spending decentralisation: The ratio of sub-central to general government spending in the respective COFOG spending area, consolidated across levels of government (OECD COFOG Database (SNA 93)).

- Income tax decentralisation: The ratio of sub-central to general government income tax revenue (OECD Tax Revenue Statistics).

- Property tax share: The ratio of revenue from property taxation to total general government tax revenue (OECD Tax Revenue Statistics). *

\section{Redistribution system variables $\left(R S_{i t}\right)$}

- Intergovernmental transfers: Transfer expenditure across levels of government as a ratio of GDP, net of sub-central expenditure on individual transfers times the vertical fiscal imbalance; horizontal transfer systems are included for Germany and Switzerland (OECD Standard National Accounts).

- Individual cash transfers: General government expenditure on individual cash transfers ("social benefits other than social transfers in kind"), as a ratio of GDP (OECD Standard National Accounts).

- $\quad$ Revenue from personal taxes: General government revenue from taxes on income, profits and capital gains of individuals, from employee's, self-employed and non-employed social security contributions, and from recurrent taxes on immovable property as a ratio of GDP (OECD Tax Revenue Statistics).

- Kakwani index of household tax progressivity: An index ranging from -1 (very regressive) to 1 (very progressive), defined as the concentration coefficient of income before taxes minus the concentration coefficient after taxes (Joumard et al., 2012 for details) (OECD Income Distribution Database).

Control variables $\left(X_{i t}\right)$

- Unemployment: Unemployment rate, age group 15 to 64 (OECD Labour Force Statistics).

- Human capital: A measure of human capital, based on the average years of total schooling per country, which measures the estimated return from years at school (Johansson et al., 2013 for details) (OECD Analytical Database).

- Urbanisation: Percentage of the national population living in urban areas (OECD Regional Statistics).

- Employment protection: Strictness of employment protection for regular contracts, individual and collective dismissals (OECD Labour Force Statistics).

- Union density: The ratio of wage and salary earners that are trade union members, divided by the total number of wage and salary earners (OECD Labour Force Statistics).

- $\quad$ Trade openness: The sum of exports and imports, divided by GDP (OECD Analytical Database).

- Effectiveness of government: World Bank governance indicator capturing the perceptions of government effectiveness (Kaufmann et al., 2010).

* Since property taxes are often an exclusive sub-central tax, the methodology for this indicator deviates from that of the other indicators. Instead of expressing a sub-central share, it measures the share of property tax revenue in total tax revenue at the general government level. 
ECO/WKP(2016)55

\subsection{Results}

\section{Fixed effects Gini regressions}

31. Results for the Gini regressions with the main fiscal decentralisation indicators revenue, tax, spending decentralisation and tax autonomy are presented in Table 2. They show an inequality-reducing impact of both revenue and expenditure decentralisation, significant at the 5\%-level. The size of the coefficients is, however, small. For example, an increase in revenue decentralisation from 20 to $30 \%$ leads to a decrease in the (from 0 to 1 ranging) Gini coefficient of roughly 0.01 , ceteris paribus. The coefficient for spending decentralisation has about the same size. The results indicate that empirically, inequalityreducing channels of spending and revenue decentralisation tend to outweigh inequality-increasing channels, but the effect is not strongly significant. Tax decentralisation and autonomy show no significant relationship with disposable income inequality at all. Thus, there seems to be no strong indication that tax competition has inequality-increasing effects on the national income distribution as a whole.

32. The regressions including function-specific spending indicators (Table 3, columns 1 to 4) show mixed results. The decentralisation of spending on economic affairs shows a negative, therefore inequalityreducing effect, which is significant at the 5\%-level. However, the effect is rather small in absolute value, as it has only one third of the size of the effects for spending and revenue decentralisation. The education decentralisation indicator, on the other hand, shows a slightly significant positive relationship with the Gini coefficient. But the impact is also small. The coefficients for social protection and health spending decentralisation, by contrast, are not significant.

33. With regards to different taxes (Table 3, columns 5 and 6), the share of property taxes in total tax revenue shows a weakly significant, inequality-increasing relationship. This result seems plausible, as real estate taxes tend to be regressive (Joumard et al., 2012). Income tax decentralisation has no discernible impact on the Gini coefficient of disposable income.

34. In conclusion, the results for the fiscal decentralisation variables indicate that while overall revenue and spending decentralisation may contribute to reducing disposable income inequality, some spending and tax areas show adverse, but small effects.

35. The individual redistribution system variables behave as expected in all regressions. Expenditure on cash benefits and revenue from personal taxes both have a highly significant, inequality-reducing relationship with the Gini coefficient of disposable income in all regressions. A much larger size of the coefficients - in absolute value - is also highly plausible, as taxes and transfers are direct tools for income redistribution. A higher degree of progressivity of household taxes also contributes to reducing inequality, but the effect is not significant in all regressions.

36. By contrast, territorial transfers between levels of government tend to raise inequality, although across all regressions. The empirical result is corroborated by Goerl and Seiferling's (2014) finding of a positive relationship between regional transfer dependency and income inequality. At first sight, this result seems counterintuitive, as one would expect an inequality-reducing rather than an inequality-increasing impact of an equalising transfer system. However, it should be kept in mind that regional transfers, as opposed to individual transfers, are not directly targeted at reducing interpersonal income inequality. Instead, their central purpose is to reduce fiscal disparities between jurisdictions, which in turn may have an indirect impact on household income inequality. Moreover, regional transfer systems can come with negative side effects if they are poorly designed. For example, transfer systems aimed at equalising revenues across regions can cause moral hazard, leading to a distortion of sub-central tax structures and less efforts for increasing tax bases and enforcing tax collection (OECD, 2013). If incentives for tax revenue generation decrease, less redistribution takes place, which directly affects income inequality. 


\section{ECO/WKP(2016)55}

Pressure from local constituents for efficient spending on redistribution might also be lower when revenues stem from intergovernmental transfers rather than local taxes.

Table 2. Fixed effects Gini regression results: General fiscal decentralisation indicators

\begin{tabular}{|c|c|c|c|c|}
\hline & \multicolumn{4}{|c|}{ Dependent variable: Gini of disposable income } \\
\hline & $\begin{array}{l}\text { (1) } \\
\text { FE }\end{array}$ & $\begin{array}{l}(2) \\
\text { FE }\end{array}$ & $\begin{array}{l}\text { (3) } \\
\text { FE }\end{array}$ & $\begin{array}{l}\text { (4) } \\
\text { FE }\end{array}$ \\
\hline $\begin{array}{l}\text { Revenue } \\
\text { decentralisation }\end{array}$ & $\begin{array}{l}-0.07^{* *} \\
(0.03)\end{array}$ & & & \\
\hline Tax decentralisation & & $\begin{array}{l}-0.03 \\
(0.02)\end{array}$ & & \\
\hline $\begin{array}{l}\text { Spending } \\
\text { decentralisation }\end{array}$ & & & $\begin{array}{l}-0.07^{* *} \\
(0.04)\end{array}$ & \\
\hline Tax autonomy & & & & $\begin{array}{l}-0.08 \\
(0.06)\end{array}$ \\
\hline $\begin{array}{l}\text { Intergovernmental } \\
\text { transfers }\end{array}$ & $\begin{array}{l}0.12^{*} \\
(0.06)\end{array}$ & $\begin{array}{l}0.12^{*} \\
(0.06)\end{array}$ & $\begin{array}{l}0.30^{* *} \\
(0.13)\end{array}$ & $\begin{array}{c}0.10 \\
(0.07)\end{array}$ \\
\hline $\begin{array}{l}\text { Individual cash } \\
\text { benefits }\end{array}$ & $\begin{array}{c}-0.50^{\star * *} \\
(0.09)\end{array}$ & $\begin{array}{c}-0.50^{* * *} \\
(0.08)\end{array}$ & $\begin{array}{c}-0.58^{* * *} \\
(0.09)\end{array}$ & $\begin{array}{c}-0.59^{* * *} \\
(0.07)\end{array}$ \\
\hline $\begin{array}{l}\text { Revenue from } \\
\text { personal taxes }\end{array}$ & $\begin{array}{c}-0.28^{* * *} \\
(0.09)\end{array}$ & $\begin{array}{c}-0.28^{* * *} \\
(0.09)\end{array}$ & $\begin{array}{c}-0.25^{\star * *} \\
(0.09)\end{array}$ & $\begin{array}{c}-0.28^{* * *} \\
(0.10)\end{array}$ \\
\hline $\begin{array}{l}\text { Kakwani index of } \\
\text { personal taxes }\end{array}$ & $\begin{array}{l}-0.07 \\
(0.04)\end{array}$ & $\begin{array}{l}-0.08^{*} \\
(0.04)\end{array}$ & $-0.07^{*}(0.04)$ & $\begin{array}{l}-0.05 \\
(0.04)\end{array}$ \\
\hline Unemployment & $\begin{array}{l}0.25^{\star \star \star} \\
(0.04)\end{array}$ & $\begin{array}{c}0.25^{\star * *} \\
(0.04)\end{array}$ & $\begin{array}{l}0.25^{\star \star *} \\
(0.04)\end{array}$ & $\begin{array}{c}0.28^{* * *} \\
(0.05)\end{array}$ \\
\hline Human capital & $\begin{array}{l}-0.02 \\
(0.04)\end{array}$ & $\begin{array}{l}-0.01 \\
(0.04)\end{array}$ & $\begin{array}{l}-0.01 \\
(0.04)\end{array}$ & $\begin{array}{l}-0.04 \\
(0.05)\end{array}$ \\
\hline $\begin{array}{l}\text { Employment } \\
\text { protection }\end{array}$ & $\begin{array}{l}0.01^{*} \\
(0.01)\end{array}$ & $\begin{array}{l}0.01 \\
(0.01)\end{array}$ & $\begin{array}{l}0.01 \\
(0.01)\end{array}$ & $\begin{array}{l}0.01 \\
(0.01)\end{array}$ \\
\hline Union density & $\begin{array}{c}0.04 \\
(0.03)\end{array}$ & $\begin{array}{c}0.03 \\
(0.04)\end{array}$ & $\begin{array}{c}0.03 \\
(0.03)\end{array}$ & $\begin{array}{c}0.03 \\
(0.05)\end{array}$ \\
\hline Urbanisation & $\begin{array}{c}-0.26 * * * \\
(0.07)\end{array}$ & $\begin{array}{c}-0.24^{* * *} \\
(0.07)\end{array}$ & $\begin{array}{c}-0.29^{\star * *} \\
(0.08)\end{array}$ & $\begin{array}{l}-0.25^{\star *} \\
(0.10)\end{array}$ \\
\hline Trade openness & $\begin{array}{c}-0.04^{* * *} \\
(0.01)\end{array}$ & $\begin{array}{c}-0.04^{* * *} \\
(0.01)\end{array}$ & $\begin{array}{c}-0.04^{* * *} \\
(0.01)\end{array}$ & $\begin{array}{c}-0.04^{* * *} \\
(0.01)\end{array}$ \\
\hline $\begin{array}{l}\text { Effectiveness of } \\
\text { government }\end{array}$ & $\begin{array}{l}-0.01 \\
(0.01)\end{array}$ & $\begin{array}{l}-0.01 \\
(0.01)\end{array}$ & $\begin{array}{l}-0.01 \\
(0.01)\end{array}$ & $\begin{array}{l}-0.01 \\
(0.01)\end{array}$ \\
\hline Constant & $\begin{array}{c}0.69^{* * *} \\
(0.14)\end{array}$ & $\begin{array}{c}0.66^{* * *} \\
(0.14)\end{array}$ & $\begin{array}{l}0.70^{* * *} \\
(0.145)\end{array}$ & $\begin{array}{c}0.74^{* * *} \\
(0.16)\end{array}$ \\
\hline Observations & 148 & 148 & 148 & 138 \\
\hline R-squared & 0.63 & 0.63 & 0.64 & 0.60 \\
\hline Number of countries & 20 & 20 & 20 & 20 \\
\hline
\end{tabular}

Note: Unbalanced panel, country and time fixed effects regressions. Robust, country clustered standard errors are given in parentheses. Asterisks $\left({ }^{* * *},{ }^{* *}\right.$ and $\left.{ }^{*}\right)$ indicate significance of the coefficients at the $1 \%, 5 \%$, and $10 \%$ level, respectively. The countries included in the regressions are Austria, Belgium, Canada, Czech Republic, Germany, Denmark, Spain, Finland, France, the United Kingdom, Greece, Ireland, Italy, the Netherlands, Poland, Portugal, Slovak Republic, Slovenia, Sweden and the United States. 
ECO/WKP(2016)55

Table 3. Fixed effects Gini regression results: Policy-area-specific fiscal decentralisation indicators

\begin{tabular}{|c|c|c|c|c|c|c|}
\hline & \multicolumn{6}{|c|}{ Dependent variable: Gini of disposable income } \\
\hline & $\begin{array}{l}\text { (1) } \\
\text { FE }\end{array}$ & $\begin{array}{l}(2) \\
\mathrm{FE}\end{array}$ & $\begin{array}{l}\text { (3) } \\
\mathrm{FE} \\
\end{array}$ & $\begin{array}{l}(4) \\
\mathrm{FE}\end{array}$ & $\begin{array}{l}5) \\
\mathrm{FE} \\
\end{array}$ & $\begin{array}{l}(6) \\
\text { FE }\end{array}$ \\
\hline $\begin{array}{l}\text { Education } \\
\text { spending } \\
\text { decentralisation }\end{array}$ & $\begin{array}{l}0.04^{*} \\
(0.02)\end{array}$ & & & & & \\
\hline $\begin{array}{l}\text { Social protection } \\
\text { spending decentr. }\end{array}$ & & $\begin{array}{l}0.05 \\
(0.5)\end{array}$ & & & & \\
\hline $\begin{array}{l}\text { Health spending } \\
\text { decentralisation }\end{array}$ & & & $\begin{array}{l}-0.1 \\
(0.01)\end{array}$ & & & \\
\hline $\begin{array}{l}\text { Econ. affairs } \\
\text { spending dec. }\end{array}$ & & & & $\begin{array}{c}-0.02^{* *} \\
(0.01)\end{array}$ & & \\
\hline $\begin{array}{l}\text { Income tax } \\
\text { decentralisation }\end{array}$ & & & & & $\begin{array}{l}-0.02 \\
(0.01)\end{array}$ & \\
\hline $\begin{array}{l}\text { Property tax } \\
\text { share }\end{array}$ & & & & & & $\begin{array}{l}0.39^{*} \\
(0.2)\end{array}$ \\
\hline $\begin{array}{l}\text { Intergovernmental } \\
\text { transfers }\end{array}$ & $\begin{array}{l}0.16^{* *} \\
(0.06)\end{array}$ & $\begin{array}{c}0.06 \\
(0.09)\end{array}$ & $\begin{array}{l}0.20^{\star} \\
(0.11)\end{array}$ & $\begin{array}{l}0.19^{* *} \\
(0.07)\end{array}$ & $\begin{array}{l}0.13^{*} \\
(0.06)\end{array}$ & $\begin{array}{l}0.11^{* *} \\
(0.05)\end{array}$ \\
\hline $\begin{array}{l}\text { Individual cash } \\
\text { benefits }\end{array}$ & $\begin{array}{c}-0.50^{* * *} \\
(0.08)\end{array}$ & $\begin{array}{c}-0.49^{* * *} \\
(0.09)\end{array}$ & $\begin{array}{c}-0.52^{* * *} \\
(0.08)\end{array}$ & $\begin{array}{c}-0.53^{* * *} \\
(0.08)\end{array}$ & $\begin{array}{c}-0.53^{* * *} \\
(0.08)\end{array}$ & $\begin{array}{c}-0.59^{* * *} \\
(0.10)\end{array}$ \\
\hline $\begin{array}{l}\text { Revenue from } \\
\text { personal taxes }\end{array}$ & $\begin{array}{c}-0.26^{* * *} \\
(0.07)\end{array}$ & $\begin{array}{c}-0.25^{\star * *} \\
(0.07)\end{array}$ & $\begin{array}{c}-0.26^{* * *} \\
(0.08)\end{array}$ & $\begin{array}{c}-0.31^{* \star *} \\
(0.07)\end{array}$ & $\begin{array}{c}-0.28^{* * *} \\
(0.10)\end{array}$ & $\begin{array}{c}-0.19^{\star \star} \\
(0.08)\end{array}$ \\
\hline $\begin{array}{l}\text { Kakwani index of } \\
\text { personal taxes }\end{array}$ & $\begin{array}{l}-0.05 \\
(0.05)\end{array}$ & $\begin{array}{l}-0.07 \\
(0.04)\end{array}$ & $\begin{array}{l}-0.07 \\
(0.04)\end{array}$ & $\begin{array}{l}-0.06 \\
(0.04)\end{array}$ & $\begin{array}{l}-0.08^{*} \\
(0.04)\end{array}$ & $\begin{array}{l}-0.08^{*} \\
(0.04)\end{array}$ \\
\hline Unemployment & $\begin{array}{c}0.25^{\star \star \star} \\
(0.04)\end{array}$ & $\begin{array}{c}0.25^{* * *} \\
(0.04)\end{array}$ & $\begin{array}{c}0.25^{\star \star *} \\
(0.04)\end{array}$ & $\begin{array}{c}0.25^{* * *} \\
(0.04)\end{array}$ & $\begin{array}{l}0.27^{\star \star *} \\
(0.04)\end{array}$ & $\begin{array}{c}0.24^{* * \star} \\
(0.04)\end{array}$ \\
\hline Human capital & $\begin{array}{l}-0.02 \\
(0.04)\end{array}$ & $\begin{array}{l}-0.02 \\
(0.04)\end{array}$ & $\begin{array}{l}-0.02 \\
(0.04)\end{array}$ & $\begin{array}{l}-0.01 \\
(0.04)\end{array}$ & $\begin{array}{l}-0.01 \\
(0.04)\end{array}$ & $\begin{array}{c}0.00 \\
(0.04)\end{array}$ \\
\hline $\begin{array}{l}\text { Employment } \\
\text { protection }\end{array}$ & $\begin{array}{c}0.01 \\
(0.01)\end{array}$ & $\begin{array}{l}0.01^{*} \\
(0.01)\end{array}$ & $\begin{array}{l}0.01^{*} \\
(0.01)\end{array}$ & $\begin{array}{l}0.01 \\
(0.01)\end{array}$ & $\begin{array}{l}0.01^{*} \\
(0.01)\end{array}$ & $\begin{array}{l}0.02^{*} \\
(0.01)\end{array}$ \\
\hline Union density & $\begin{array}{c}0.04 \\
(0.03)\end{array}$ & $\begin{array}{c}0.03 \\
(0.04)\end{array}$ & $\begin{array}{c}0.04 \\
(0.03)\end{array}$ & $\begin{array}{l}0.04 \\
(0.03)\end{array}$ & $\begin{array}{c}0.03 \\
(0.04)\end{array}$ & $\begin{array}{l}-0.00 \\
(0.04)\end{array}$ \\
\hline Urbanisation & $\begin{array}{c}-0.24^{* * *} \\
(0.08)\end{array}$ & $\begin{array}{c}-0.22^{* *} \\
(0.10)\end{array}$ & $\begin{array}{c}-0.26^{\star \star *} \\
(0.08)\end{array}$ & $\begin{array}{c}-0.27^{* \star *} \\
(0.07)\end{array}$ & $\begin{array}{c}-0.25^{\star * *} \\
(0.07)\end{array}$ & $\begin{array}{c}-0.23^{* * *} \\
(0.07)\end{array}$ \\
\hline Trade openness & $\begin{array}{c}-0.03^{* * *} \\
(0.01)\end{array}$ & $\begin{array}{c}-0.04^{* * *} \\
(0.01)\end{array}$ & $\begin{array}{c}-0.04^{* *} \\
(0.01)\end{array}$ & $\begin{array}{c}-0.04^{* * *} \\
(0.01)\end{array}$ & $\begin{array}{c}-0.04^{* * *} \\
(0.01)\end{array}$ & $\begin{array}{c}-0.04^{* * *} \\
(0.01)\end{array}$ \\
\hline $\begin{array}{l}\text { Effectiveness of } \\
\text { government }\end{array}$ & $\begin{array}{l}-0.00 \\
(0.01)\end{array}$ & $\begin{array}{l}-0.01 \\
(0.01)\end{array}$ & $\begin{array}{l}-0.01 \\
(0.01)\end{array}$ & $\begin{array}{l}-0.00 \\
(0.01)\end{array}$ & $\begin{array}{l}-0.01 \\
(0.01)\end{array}$ & $\begin{array}{l}-0.01 \\
(0.01)\end{array}$ \\
\hline Constant & $\begin{array}{c}0.63^{* * *} \\
(0.16) \\
\end{array}$ & $\begin{array}{l}0.64^{* * *} \\
(0.16) \\
\end{array}$ & $\begin{array}{l}0.66^{* \star *} \\
(0.15)\end{array}$ & $\begin{array}{c}0.66^{* * *} \\
(0.17)\end{array}$ & $\begin{array}{c}0.64^{* * *} \\
(0.14)\end{array}$ & $\begin{array}{c}0.57^{* * *} \\
(0.15)\end{array}$ \\
\hline Observations & 140 & 140 & 140 & 134 & 148 & 148 \\
\hline R-squared & 0.64 & 0.63 & 0.63 & 0.65 & 0.63 & 0.64 \\
\hline $\begin{array}{l}\text { Number of } \\
\text { countries }\end{array}$ & 19 & 19 & 20 & 19 & 20 & 20 \\
\hline
\end{tabular}

Note: Unbalanced panel, country and time fixed effects regressions. Robust, country clustered standard errors are given in parentheses. Asterisks $\left({ }^{* *},{ }^{* *}\right.$ and ${ }^{*}$ ) indicate significance of the coefficients at the $1 \%, 5 \%$, and $10 \%$ level, respectively. The countries included in all regression are Austria, Belgium, Canada, Czech Republic, Germany, Denmark, Spain, Finland, France, the United Kingdom, Greece, Ireland, Italy, the Netherlands, Portugal, Slovak Republic, Slovenia, Sweden and the United States. Poland is included in some of the regressions.

37. As to the control variables, most notable are a strongly significant, inequality-increasing effect of the unemployment rate in all regressions versus significantly decreasing effects of both urbanisation and openness to trade. All other controls are only weakly or not at all significant. The result for trade openness is interesting as evidence on its effects on inequality is mixed throughout the literature. ${ }^{5}$ Given that larger

5. For a discussion, see Koske et al. (2012). 
countries tend to be less open than smaller ones, additional regressions were run with population size added as a control variable, in order to check whether trade openness does not just serve as a proxy for population size. In these regressions, the coefficients for trade openness remain highly significant.

\section{Fixed effects income decile ratio regressions}

38. The percentile ratio regression results confirm the assumption of varying effects of fiscal decentralisation for different segments of the income distribution. For the upper part of the income distribution, fiscal decentralisation tends to reduce the gap between different deciles and the median. In the P70/P50, P80/P50 and P90/P50 ratio regressions, the coefficients for all four general decentralisation indicators are negative, and they are highly significant for spending decentralisation (Figure 4).

Figure 4. Fixed effects percentile ratio regression results: General decentralisation indicators

Regression coefficients

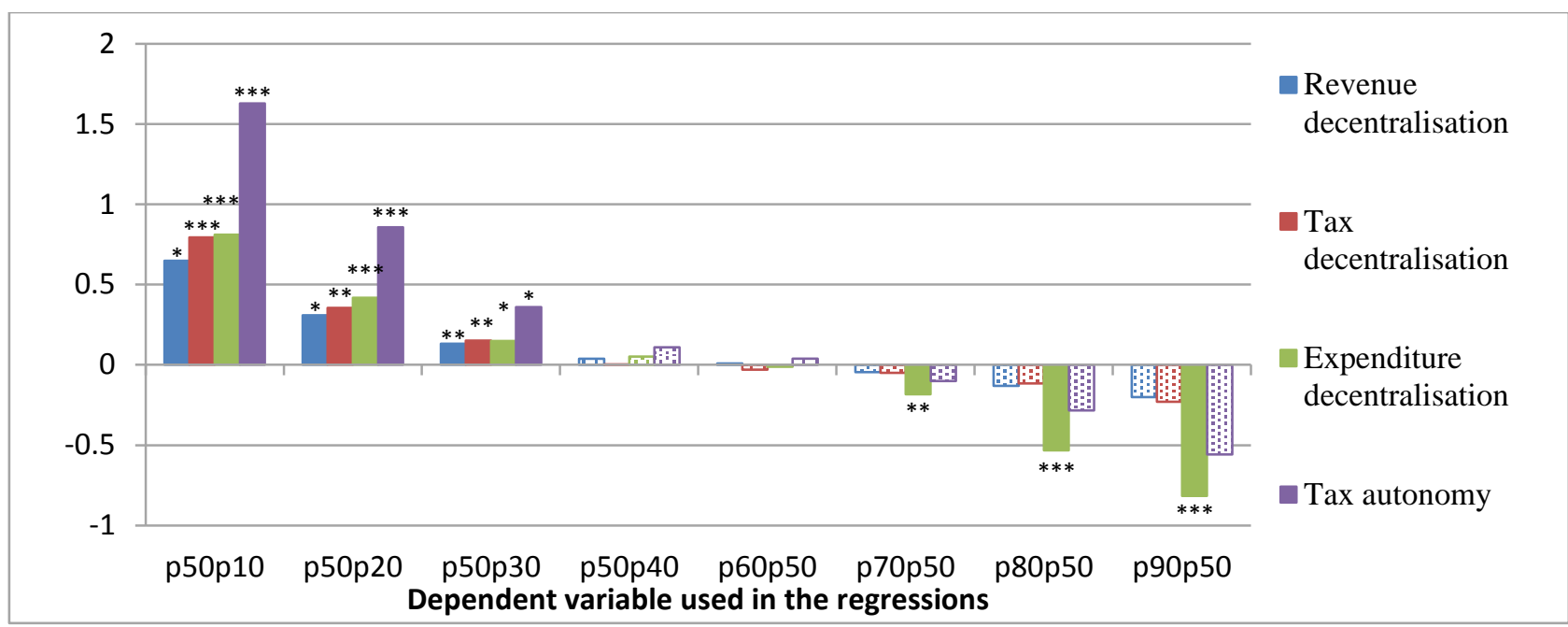

Note: The figure shows the magnitude of beta-coefficients of selected decentralisation indicators. The regressions run to obtain the coefficients coincide with the Gini regressions except for the dependent variable, which was replaced with different percentile ratios of disposable income. No regressions were run for the P100/P50 ratio because too few data points were available. Analogously to the Gini regressions, the percentile ratio regressions were run separately for each fiscal decentralisation indicator. A filled column implies significant results, a dotted column implies insignificant results. Asterisks $\left({ }^{* *},{ }^{* *}\right.$ and ${ }^{*}$ ) indicate the level of significance at the $1 \%$, $5 \%$, and $10 \%$ level, respectively. Full regression results are presented in Tables A.2 to A.5.

Source: Secretariat calculations.

39. For the lower part of the income distribution, the effects are reversed. Here, fiscal decentralisation tends to increase the gap between the median and low income deciles. From the P50/P10 ratio up until the P50/P30 ratio, the coefficients for all four decentralisation indicators are positive, and statistically significant in all cases. The tax autonomy coefficient is about twice the size in absolute value of the other coefficients. An increase in sub-central tax autonomy from a share of $20 \%$ of total tax revenues to $30 \%$ would drive up the P50/P10 ratio by almost 0.16 , ceteris paribus. Regressions with the middle ratios (P50/P40, P60/P50) do not yield significant results.

40. Figure 5 shows the regression coefficients for the percentile ratio regressions with policy-areaspecific decentralisation indicators. Overall, the same pattern emerges as for the traditional decentralisation indicators. Coefficients tend to be income gap-decreasing for the upper half of the distribution and gapincreasing for the lower half of the distribution. The coefficients are, however, smaller. Noticeable are the significantly gap-decreasing coefficients for social protection spending decentralisation for the P80/P50 and P90/P50 ratios. This hints at a somewhat stronger recognition of middle class interests in decentralised 
environments with regards to social benefits. The decentralisation of other spending categories has a comparatively small effect or is not significant. ${ }^{6}$ At the lower half of the income distribution, income tax decentralisation shows the largest gap-increasing effect for the P50P10 and P50P20 ratios. Property taxes show a different pattern. They have a significant inequality-increasing effect both in the lower half of the distribution (P50/P30) and in the upper half of the distribution (P60/P50 to P90/P50) (Tables A.2 to A.5).

Figure 5. Fixed effects percentile ratio regression results: Policy-area-specific decentralisation indicators Regression coefficients

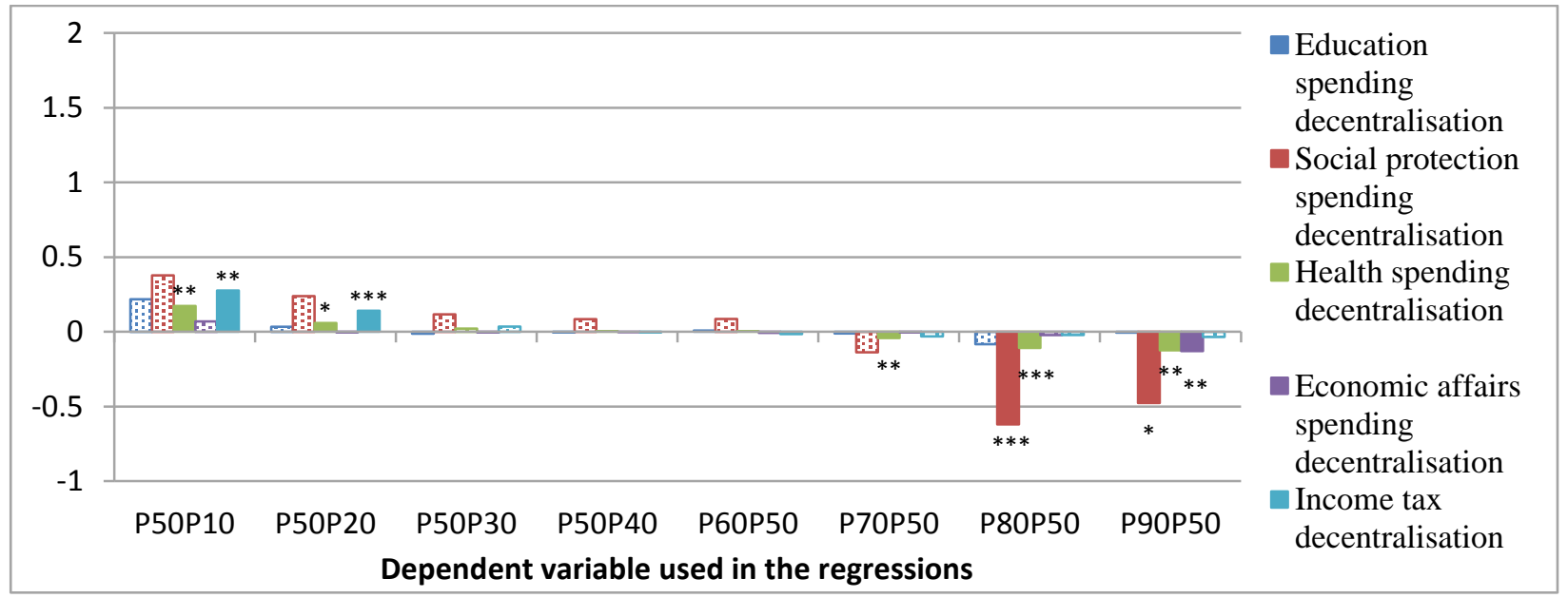

Note: The figure shows the magnitude of beta-coefficients of selected decentralisation indicators. The regressions run to obtain the coefficients coincide with the Gini regressions except for the dependent variable, which was replaced with different percentile ratios of disposable income. No regressions were run for the P100/P50 ratio because too few data points were available. Analogously to the Gini regressions, the percentile ratio regressions were run separately for each fiscal decentralisation indicator. A filled column implies significant results, a dotted column implies insignificant results. Asterisks $\left({ }^{* *},{ }^{* *}\right.$ and ${ }^{*}$ ) indicate the level of significance at the $1 \%$, $5 \%$, and $10 \%$ level, respectively. The results for property taxes are not displayed in this graph as the indicator refers to a different base. Numerical results for all policy-area-specific decentralisation regression coefficients can be found in Table A.6.

Source: Secretariat calculations.

41. Interpreting the effects jointly, it seems that the group mainly benefiting from fiscal decentralisation are middle income earners. Their gap to high incomes is reduced, notably through spending decentralisation. It seems plausible that when spending decisions are taken locally, preferences of the middle class are taken more strongly into account. Low income groups seem, however, not to benefit from decentralisation, as the gap between low and middle incomes widens. In this case, both revenue and spending decentralisation have an adverse effect.

42. Underlying reasons for lower-middle to high incomes converging and low incomes diverging are difficult to discern, and a detailed analysis of all the potential channels would go beyond the scope of this paper and requires further research. One of the reasons might be that sub-central taxation could be less progressive than central government taxation, since sub-central governments might be inclined to tax lowincome households, which are less mobile, at relatively higher tax rates. Yet decentralised tax and social security systems do not seem less progressive than more centralised ones. ${ }^{7}$ The Kakwani index, which

6. For education, this could be due to very long lags and, in general, decentralisation as measured by spending flows may not imply decentralisation of decision-making.

7. To test this hypothesis, the sub-central to total tax revenue ratio is set against the income tax plus employee and employer social contributions - both with and without taking into account cash benefits - for income earners with $67 \%$ of the median income in each country. Moreover, progressivity for the $67 \%$ is set against the progressivity for the $167 \%$ of the median income. The results suggest that progressivity for low-income groups declines first with rising decentralisation but rises again slightly in very decentralised settings (data taken from OECD, 2015). 
measures progressivity of personal income taxes, provides a similar picture: progressivity is lower when taxes are either strongly centralised or decentralised, while reaching the maximum at intermediate levels of decentralisation. Spending patterns neither provide a clear picture: Social spending is not lower in decentralised countries, and there are no signs that it is less focused on low-income households there.

43. To test whether decentralisation widens the income distribution as a whole, regressions were also run with the P90/P10 ratio. The coefficients are statistically significant and positive for revenue and tax decentralisation as well as tax autonomy. The effect is again largest for tax autonomy, where a change from $20 \%$ to $30 \%$ would cause the P90/P10 ratio to increase by 0.2 . The fact that spending decentralisation does not have a significant effect on the P90/P10 ratio seems plausible, given the significant gap-reducing effects in the upper part of the income distribution.

44. Full results for the percentile ratio regressions with the general decentralisation indicators are presented in Tables A.2 to A.5. Worth mentioning is that the coefficients of the individual transfer system variables deliver plausible results: Individual cash benefits show a large and strongly significant gapreducing effect in the lower half of the income distribution. Revenues from personal taxes are gap-reducing in the upper part of the distribution. The Kakwani index shows gap-reducing effects along the entire distribution. By contrast, intergovernmental transfers are gap-increasing in the lower half and show mostly no effect in the upper half of the distribution.

45. Finally, section 2 emphasised that theoretical predictions on the relationship between fiscal decentralisation and income inequality depend to a considerable extent on the assumptions made about inter-jurisdictional mobility. Whether fiscal decentralisation leads to increased taxpayer mobility and reduces tax progressivity cannot be answered with national-level data. It requires a thorough analysis of regional and individual data over time and may likely produce different outcomes for different countries. What can be taken from the empirical results, however, is that tax autonomy and income tax decentralisation do not seem to have a significant impact on the national gap between high and middle disposable income, neither widening nor reducing it.

\subsection{Robustness checks}

46. In order to test the robustness of the regression results, two other specification sets were run for the four general decentralisation indicators (Box 2). A first concern is endogeneity, caused by reverse causality. It could be the case that in countries with higher income inequality, especially across regions, there is more political pressure for decentralised policies, rather than fiscal decentralisation causing inequality (Beramendi, 2003). To control for this potential endogeneity, limited-information maximum likelihood (LIML) regressions with one and two-year lags of the decentralisation indicators as instruments were employed. The reasoning behind using lagged decentralisation indicators is that past levels of decentralisation are unlikely to be affected by the current level of income inequality, but the reverse can be assumed. LIML asymptotically coincides with two-stage least squares (2SLS), but has a smaller bias for finite samples when instruments are weak (Cameron and Trivedi, 2010; Baum et al., 2007). Results of the first stage regressions indicate that the one and two-year lagged decentralisation variables are strong instruments for the case of revenue decentralisation and tax autonomy (with an F-statistic well over 10). In turn, they are weak instruments for tax and expenditure decentralisation (with an F-statistic well under 10). ${ }^{8}$ However, in the two latter cases, the Stock-Yogo weak ID test suggests a bias no larger than $10 \%$ in LIML estimations.

8. Revenue decentralisation: F-statistic of 14.37, tax decentralisation: F-statistic of 4.92, spending decentralisation: F-statistic of 1.04, tax autonomy: F-statistic of 77.09. 
47. Another validity concern when using panel data is the possibility of cross-sectional dependence in the error terms. Cross-sectional dependence may lead to biased standard errors in standard fixed-effects estimations (De Hoyos et al., 2006). For this reason, one specification set was run with country-fixed effects and Driscoll and Kraay standard errors (Driscoll and Kraay, 1998 and Hoechle, 2007). These are robust not only to heteroskedasticity and autocorrelation, but also to cross-sectional dependence.

\section{Box 2. Regression specifications for the robustness checks}

- $\quad$ Specification set I: Fixed effects regressions with robust, country-clustered standard errors, country and time fixed effects.

- $\quad$ Specification set II: Limited-information maximum likelihood (LIML) estimation with one and two-year lagged decentralisation variables as instruments, country and time fixed effects.

- Specification set III: Fixed effects regressions with Driscoll and Kraay standard errors, country fixed effects, no time fixed effects.

Fiscal decentralisation variables were introduced separately in all specification sets in order to avoid multicollinearity. All specification sets use the same redistributive and control variables.

48. Figure 6 presents the coefficients of the general decentralisation indicators for regression specifications I to III with the Gini coefficient as the dependent variable. The coefficients for revenue and spending decentralisation, which were significant in the fixed effects regressions, lose their significance in the two other specification sets. While the coefficients of specification set III keep the same sign as those of the fixed effects regressions, the coefficients flip signs for the LIML estimations in two out of four cases. The individual redistribution variables also show some instability across specifications, as they lose in significance in the LIML estimations (Table A.7). For the control variables, unemployment and trade openness remain highly statistically significant across all regression specifications.

Figure 6. Robustness checks for the Gini regressions: Selected fiscal decentralisation coefficients Dependent variable: Gini coefficient

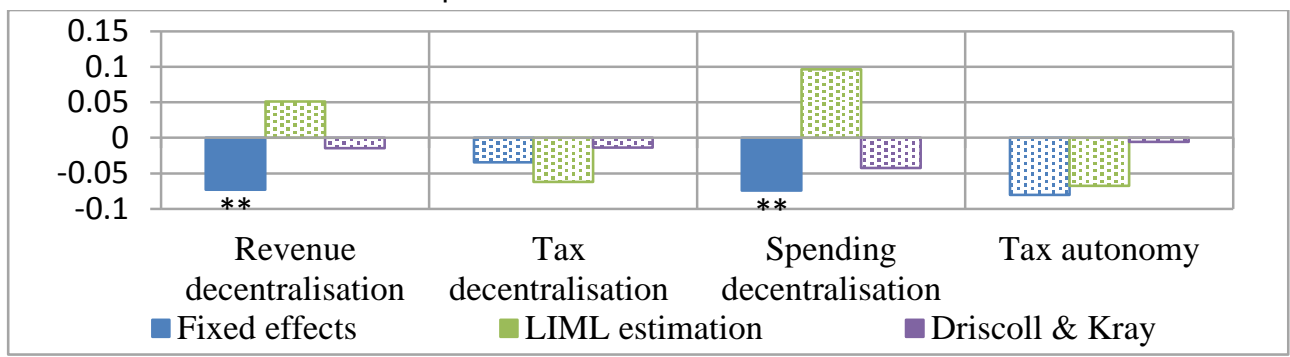

Note: The figure shows the magnitude of beta-coefficients of selected decentralisation indicators for different specification sets. Regressions were run separately for each fiscal decentralisation indicator. Uniform fillings of the bars imply significant results, dotted patterns imply insignificant results. Asterisks $\left({ }^{* * *},{ }^{* *}\right.$ and ${ }^{*}$ ) indicate the level of significance at the $1 \%, 5 \%$, and $10 \%$ level, respectively. The full results of specification sets II and III can be found in Table A.7.

Source: Secretariat calculations.

49. By contrast, the percentile ratio regressions show much more stability across specifications (Figure 7). Tax decentralisation, spending decentralisation and tax autonomy remain significant across all three specification sets for the P50/P10 ratio regressions. Revenue decentralisation is statistically significant in two out of the three specification sets. For the P90/P50 regressions, spending decentralisation is highly significant in two out of three specifications. The results for the redistribution and control variables also remain more stable across specifications in the percentile ratio regressions. 
50. In conclusion, the percentile ratio regressions produce results for the general fiscal decentralisation indicators that are quite stable with regards to concerns about both endogeneity, serial correlation and cross-sectional dependence. The greater degree of stability compared with the Gini regressions likely reflects the fact that the Gini is a rather coarse measure to capture the effects of decentralisation on the income distribution.

Figure 7. Robustness checks for the percentile ratio regressions: Selected fiscal decentralisation coefficients Panel a) Dependent variable: P50/P10 ratio

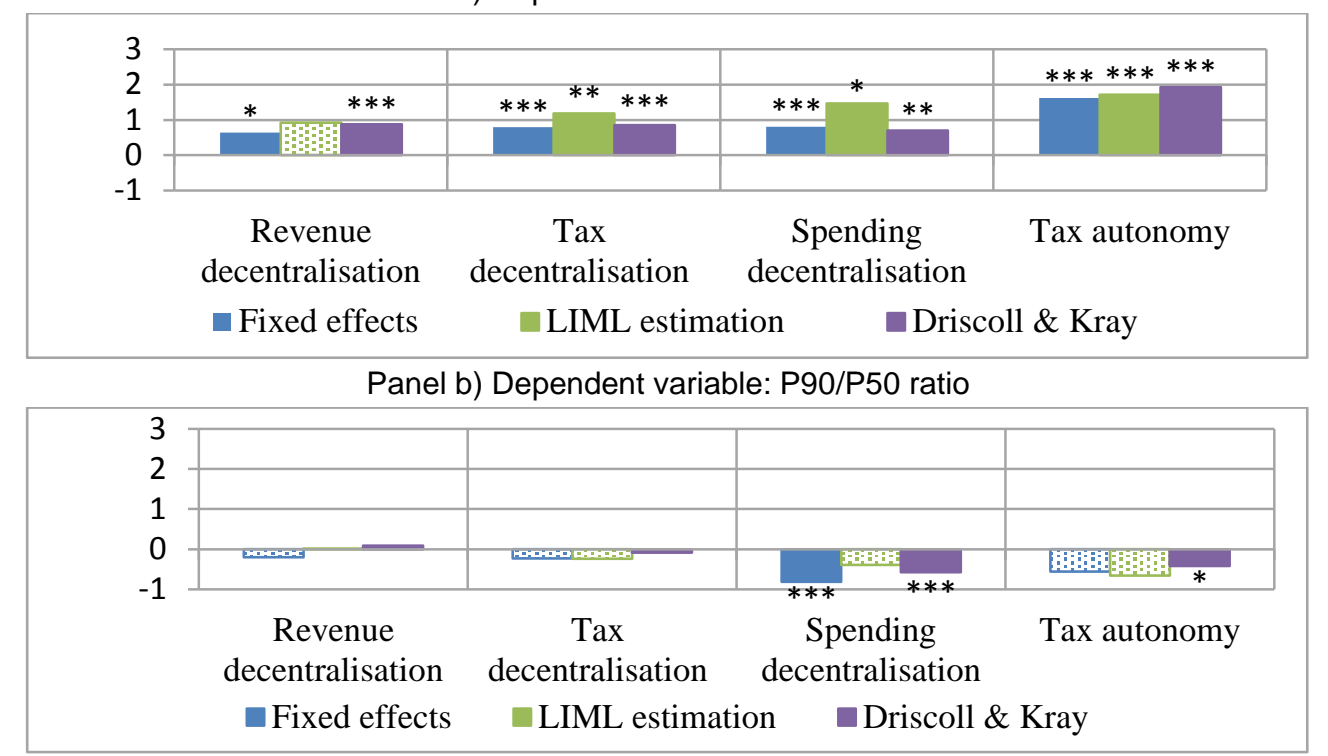

Note: The figure shows the magnitude of beta-coefficients of selected decentralisation indicators for different specification sets. Regressions were run separately for each fiscal decentralisation indicator. Uniform fillings of the bars imply significant results, dotted patterns imply insignificant results. Asterisks $\left({ }^{* * *},{ }^{* *}\right.$ and $\left.{ }^{*}\right)$ indicate the level of significance at the $1 \%, 5 \%$, and $10 \%$ level, respectively. A summary table of specification sets II and III for the percentile ratio regressions can be found in Table A.8.

Source: Secretariat calculations.

51. A number of additional robustness checks were carried out:

- Interactions between fiscal decentralisation and redistribution policy variables were separately added into the fixed effects Gini regressions. Doing so produces significant coefficients for the interaction term between fiscal decentralisation and the Kakwani index of tax progressivity and for the interaction term between fiscal decentralisation and regional transfer expenditure (Table A.9.). The coefficient of the interaction term of fiscal decentralisation and the Kakwani index is significant for all general decentralisation indicators, and is negative in all cases. This implies that decentralisation has a stronger inequality-reducing effect the stronger the progressivity of the tax system. The coefficients of the interaction terms between fiscal decentralisation and regional transfers are also negative and significant in the case for revenue, tax and spending decentralisation. This result is interesting as regional transfers themselves have a positive and significant coefficient in these regressions. This seems to imply that while regional transfers increase inequality, stronger decentralisation seems to reverse this effect. In other words, in more decentralised countries, regional transfers have an equalising effect on income inequality. Interactions with the remaining redistribution policy variables do not produce significant coefficients.

- Given their prevalence in the literature (Neyapti (2006), Goerl and Seiferling (2014), Sepulveda and Vazquez (2011)), interactions of decentralisation indicators and good governance as well as government sector size were also tested in the Gini regressions. These interaction terms do, however, not yield significant results. This is to be expected given the study's sample of 
developed countries, where one can assume that most governments spend a sufficient amount on the right spending items and that well-functioning institutions are in place.

- A set of regressions was run in order to check the effect of fiscal decentralisation on market income inequality. For these regressions, the dependent variable was replaced with the Gini coefficient of market income, and the individual and regional transfer variables were eliminated from the equations. The regressions lead to insignificant results for all fiscal decentralisation indicators except for the decentralisation of economic affairs spending.

\section{Income inequality within regions and decentralisation}

52. Cross-country studies on income inequality and fiscal decentralisation have so far been mainly carried out at the national level. What gets lost, when using national-level data, is the spatial dimension of inequality. This dimension can shed further light on the channels through which decentralisation might affect inequality. For instance, the theoretical section has shown that whether decentralisation reduces or exacerbates income inequality depends on the extent of inter-jurisdictional mobility and income sorting. Regional data can reveal whether there is a strong regional variation of the income distribution in countries and if certain income groups are located in certain regions. They allow analysing whether decentralisation contributes to these phenomena. The reverse can also be addressed, i.e. whether decentralisation can help to reduce differences in income distributions across regions, through direct or indirect channels.

53. Therefore, while it is relevant for national policy-makers to know the effects of decentralisation on country-wide inequality, the regional dimension also matters. It might reveal the need for a correction of policies that otherwise remains unobserved.

54. What impedes the empirical investigation is the scarcity of cross-country regional inequality data. Producing large enough sample sizes to get reliable results at the regional level, and making regional inequality data internationally comparable constitutes a major effort. The OECD has started collecting data on regional (TL2 ${ }^{9}$ ) income inequality and poverty. So far, observations for one year (around 2010) are available for 28 OECD countries (Piacentini, 2014). The data allow for a first descriptive analysis of the above questions. A more profound regression analysis can be carried out once more data become available. This section presents some stylized facts on regional income inequality and decentralisation and tests for indications of income sorting across jurisdictions.

\subsection{Stylised facts}

55. When looking at regional (TL2) Gini coefficients of disposable income across the OECD, distinct geographic patterns emerge both across and within countries. Levels of regional Gini coefficients are small in the Nordic and most Eastern European countries as well as parts of central Europe, while they are particularly large in Chile and Mexico and parts of the United States (Figure 8, panel a). Within many countries, geographic areas extending beyond TL2 with similar levels of inequality emerge. For instance, inequality tends to be lower in the north than in the south for the United States and Mexico. In Germany, a difference between the east and west is visible, while in France there is a difference between the north-west and the south-east.

56. Countries with high levels of regional Gini coefficients also tend to have a higher variation in inequality between regions (Figure 8, panel b). The difference between the smallest and largest regional Gini coefficient is highest in Mexico, Chile and the United States, while it is smallest in New Zealand. In

9. The OECD Territorial Level 2 (TL2) corresponds to the first administrative tier of sub-central government. For example, for Germany, TL2 corresponds to the Länder, for the United States it corresponds to the states. For a more detailed description of the OECD regional typology, see OECD (2009). 
four countries (Belgium, the United Kingdom, Israel, the United States), high inequality in the capital region constitutes a significant outlier with regards to other regions.

Figure 8. Regional (TL2) disposable income inequality

Panel a) Level of Gini coefficients, around 2010

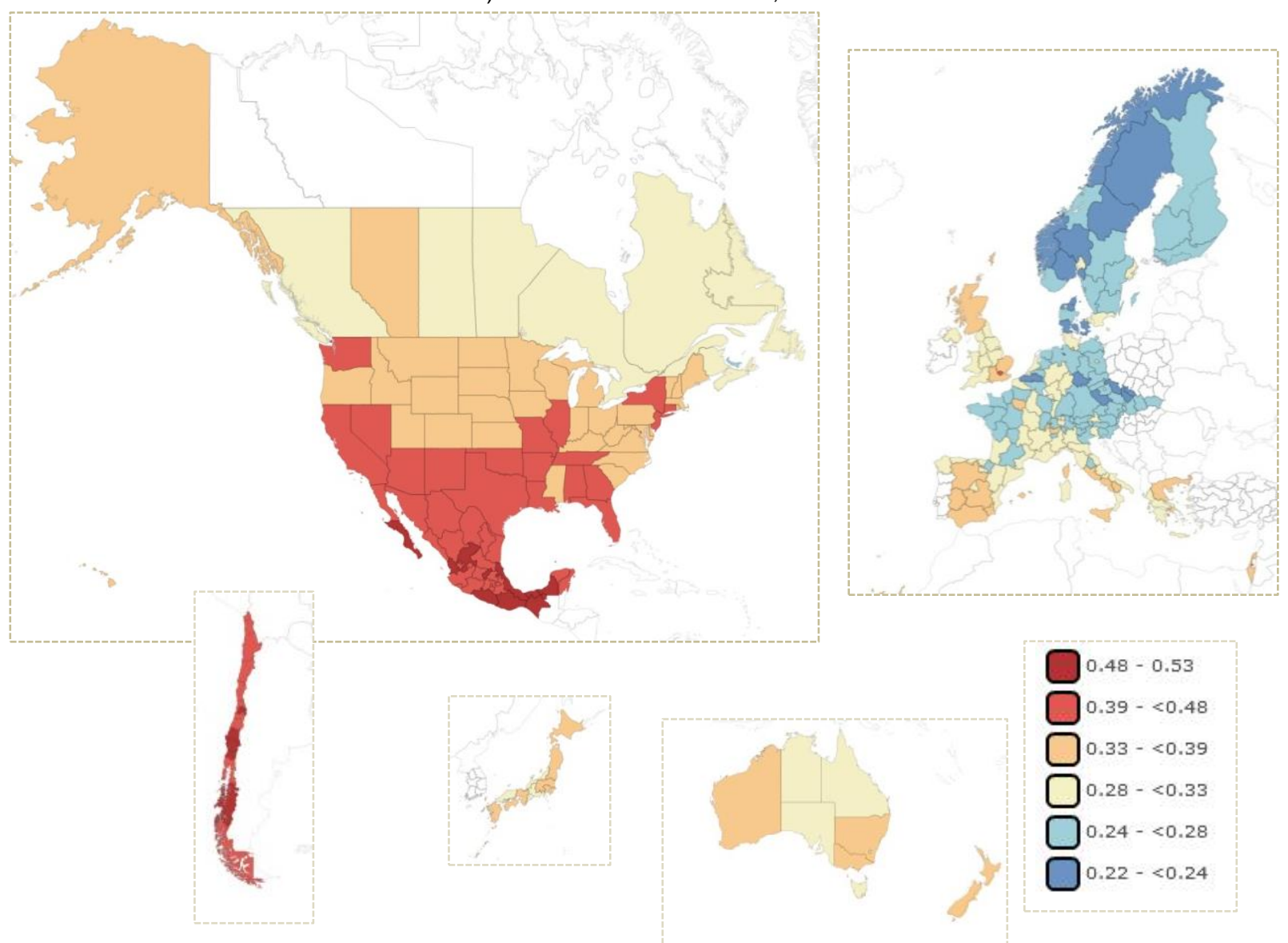

Panel b) Range of regional Gini coefficients, around 2010

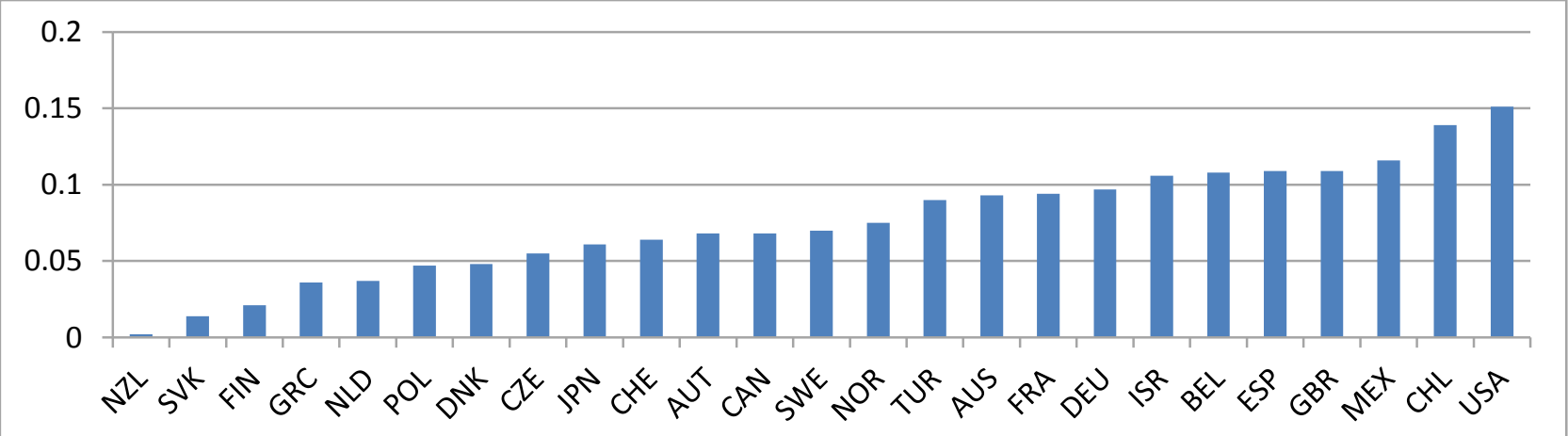

Note: The term "range" refers to the difference between the highest and the lowest regional Gini coefficient in a country.

Source: OECD "Income distribution", OECD Social and Welfare Statistics (database),

DOI: http://dx.doi.org/10.1787/data-00654-en; OECD Regional Statistics (database), DOI: http://dx.doi.org/10.1787/region-data-en. 
57. The range of regional Gini coefficients within OECD countries is slightly positively related with the degree of fiscal decentralisation (Figure 9). This implies that countries that are more decentralised also tend to have a greater variation of income inequality across regions. These results should be interpreted carefully, however, as they do not imply much about causality. First, other factors influencing inequality are not controlled for. For example, the range of Gini coefficients in a country is correlated with the number of TL2 regions. Second, the direction of causality is ambiguous. In countries with more heterogeneity across regions, there might be more political pressure for decentralisation rather than decentralisation causing more heterogeneity.

Figure 9. Range of regional (TL2-level) Gini coefficients of disposable income and decentralisation

Around 2010

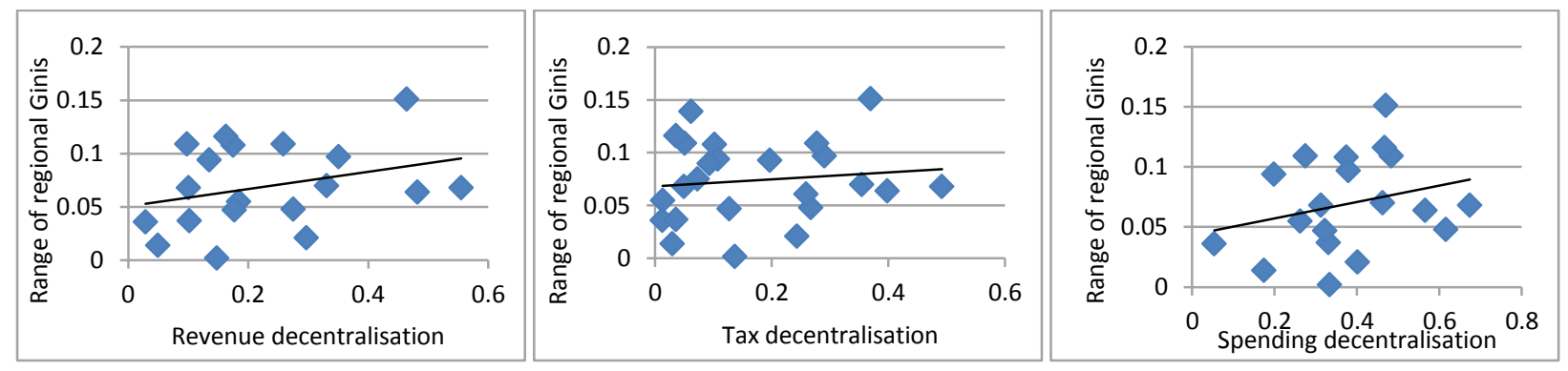

Note: The term "range" refers to the difference between the highest and the lowest regional Gini coefficient in a country.

Source: OECD "Income distribution", OECD Social and Welfare Statistics (database), DOI: http://dx.doi.org/10.1787/data-00654-en.

\subsection{Decentralisation and income sorting}

58. Income sorting implies that households with similar income characteristics are concentrated in the same jurisdictions. A high degree of income sorting implies that income differences within a jurisdiction are low, while differences across jurisdictions are high. Fiscal decentralisation may contribute to income sorting via sub-central tax and spending autonomy, as different tax schedules and public service benefits may attract different income groups. The impact depends upon the willingness of households to move due to differences in tax schedules or social transfer levels.

59. Empirical evidence on the effects of decentralisation on income sorting is scarce and the results are mixed. Schaltegger et al. (2011) find evidence of income sorting across Swiss communities due to local tax autonomy. Another Swiss study detects evidence of sorting of high-income households into low-tax municipalities (Basten et al., 2014). Evidence from the Boston Metropolitan Area in turn indicates that political factors only play a very marginal role in the income sorting process, which is mainly driven by housing quality and amenities, which are only little influenced by government (Davidoff, 2005).

\section{Indications for the income distribution as a whole}

60. Figure 10 shows the level of regional Gini coefficients versus the national Gini coefficient. In the case of notable income sorting across TL2 regions, one would expect most regional Gini coefficients in a country to be considerably smaller than the national Gini coefficient. In all countries, the national Gini coefficient lies in between lower and higher regional Gini coefficients. In two countries where national inequality is particularly high, Chile and Turkey, the national Gini coefficient lies at the upper end of the distribution of regional Gini coefficients. This may provide some indication for income sorting. 
Figure 10. Regional (TL2) Gini coefficients of disposable income by country

Around 2010

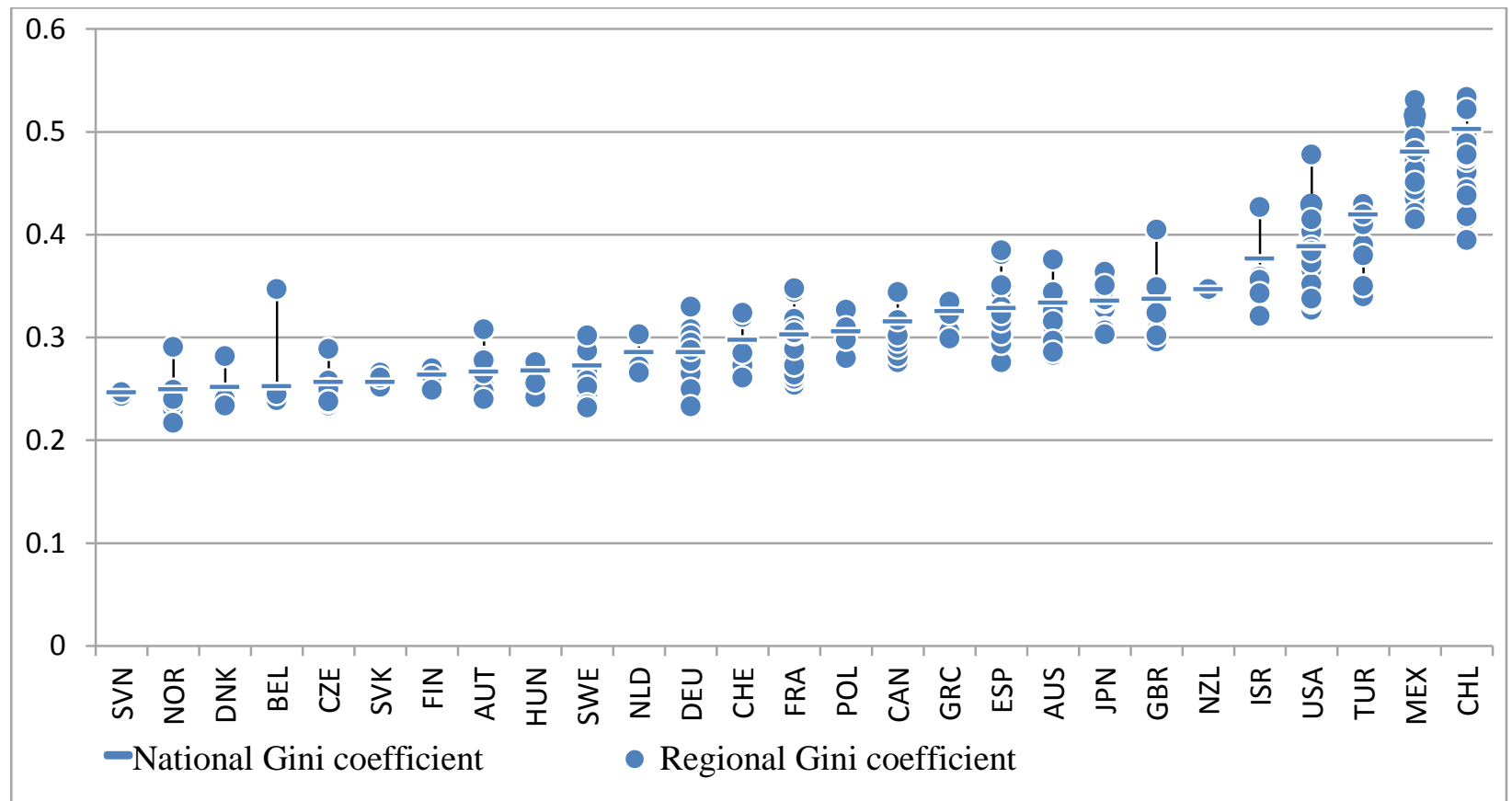

Source: OECD "Income distribution", OECD Social and Welfare Statistics (database),

DOI: http://dx.doi.org/10.1787/data-00654-en; OECD Regional Statistics (database), DOI: http://dx.doi.org/10.1787/region-data-en.

61. Analysing the difference between the national Gini coefficient and the median of regional Gini coefficients gives an idea of the relationship between inequality within regions and inequality in the country as a whole. If the difference is large, then national inequality is substantially higher than inequality in at least half of the regions. Figure 11 shows that there is no particular relationship between the difference of the national and the median regional Gini coefficient and tax autonomy in OECD countries. This result also does not point towards notable income sorting across TL2 regions. 
Figure 11. The difference between national and regional median Ginis versus tax autonomy Around 2010

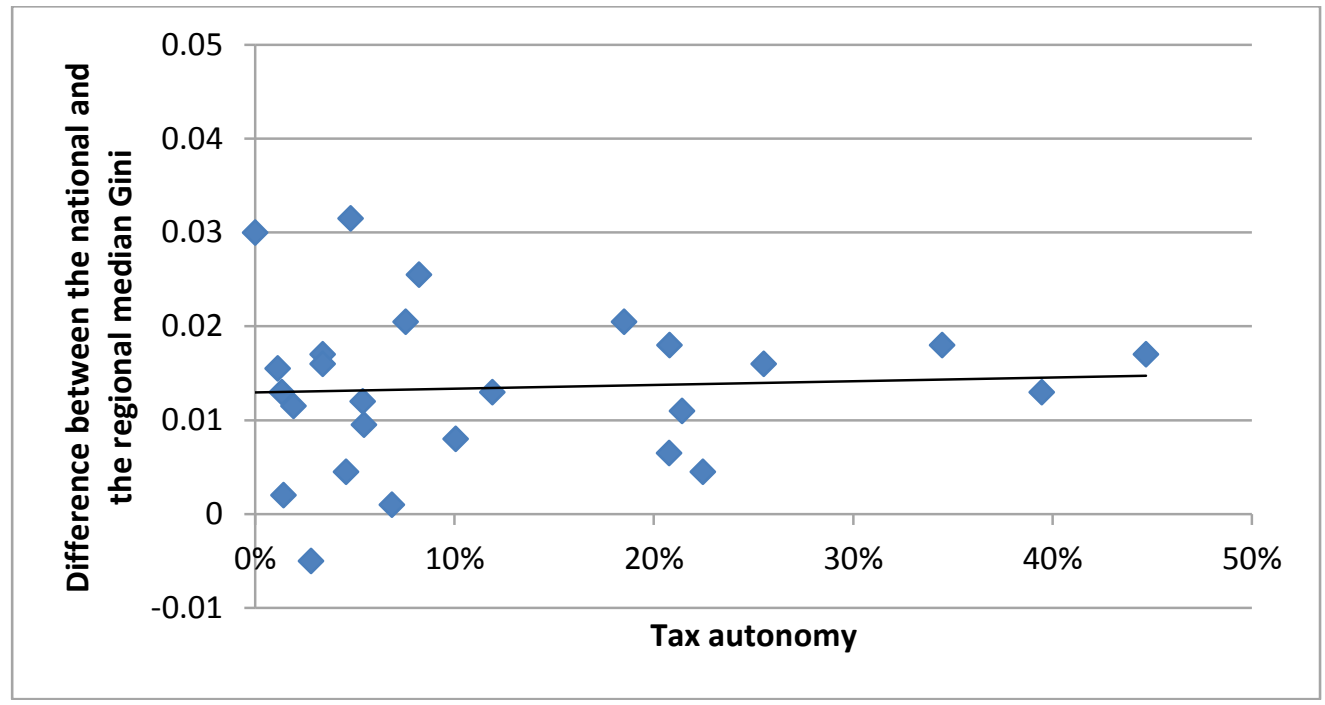

Source: OECD Fiscal Decentralisation Database, www.oecd.org/tax/federalism/oecdfiscaldecentralisationdatabase.htm; OECD "Income distribution", OECD Social and Welfare Statistics (database), DOI: http://dx.doi.org/10.1787/data-00654-en; OECD Regional Statistics (database), DOI: http://dx.doi.org/10.1787/region-data-en.

\section{Sorting indications by income quintile}

62. A way of detecting potential income sorting for different income groups is to analyse to what extent mean disposable income varies between regions by income quintile. For instance, if the variation of the mean income of the poorest $20 \%$ across regions is particularly high with regards to the regional variation of other income quintiles in a country, this might indicate that there are pockets of poverty concentrated in some regions. The analogous case can be made for the top $20 \%$ incomes, indicating a concentration of wealthy individuals in some regions. Figure 12 shows the coefficient of variation of regional mean disposable income for each country by quintile. The first income quintile stands for the poorest $20 \%$ and the fifth quintile for the richest $20 \%$. Some countries, such as the United Kingdom and Switzerland, show a relatively high variation in the top income quintile with respect to other income quintiles. This indicates that regional differences are primarily driven by the regional variation of top incomes. By contrast, other countries show the highest variation in lower income quintiles (Belgium, Israel, Spain and Turkey). In again other countries, such as Slovakia and Greece, the quintile variation is small.

63. As previously emphasised, these results should only be treated as a first indication. What cannot be seen in the data is whether heterogeneity has grown historically due to differences in economic factors in regions, or whether it has been driven by an active sorting process due to decentralisation. 
Figure 12. Coefficient of variation of mean disposable income across TL2 regions, by quintile Around 2010

Group A: Countries with a moderate variation of mean income across regions in the highest and lowest quintile and low variation in the middle quintiles $(2,3$ and 4$)$
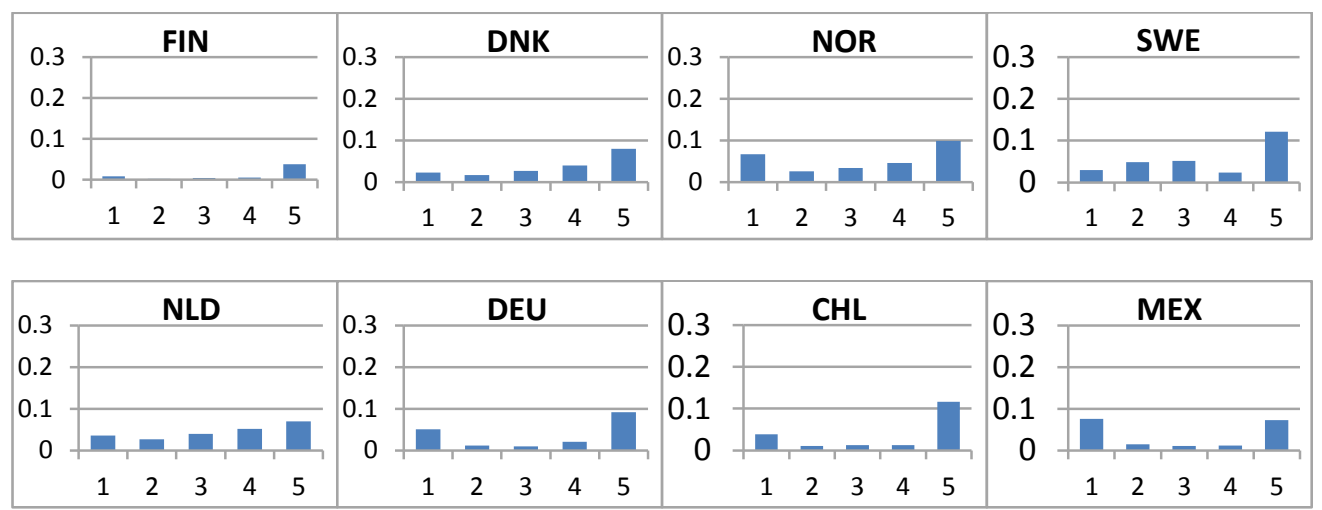

Group B: Countries with a higher variation across regions in all quintiles, which tends to increase by quintile
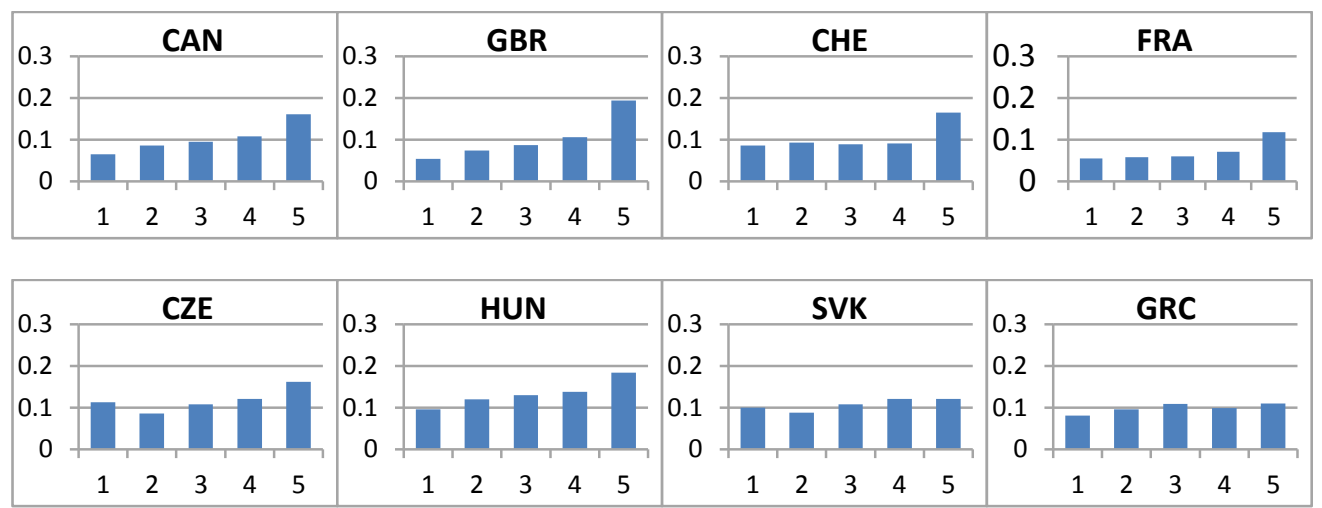

Group C: Countries with a higher variation across regions in all quintiles, which tends to decrease by quintile

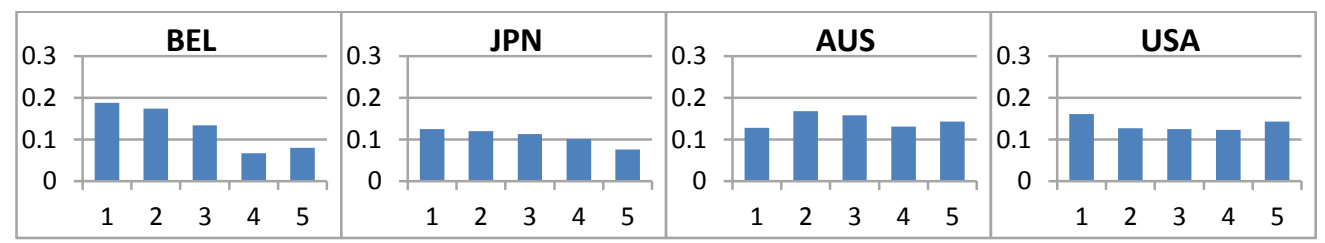

Group D: Countries with a high variation across regions in all quintiles, which tends to decrease by quintile

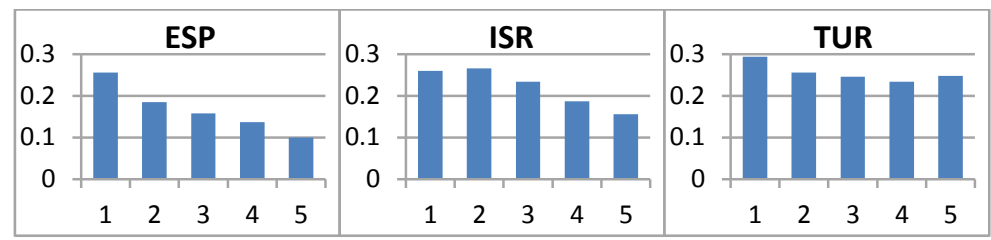

Note: Numbers along the $x$-axis stand for income quintiles $(1=$ poorest $20 \%, 5=$ richest $20 \%)$. The $Y$ axis shows the coefficient of variation of mean quintile income across TL2 regions. For example, in order to calculate the coefficient of variation of the first quintile across TL2 regions in Germany, the mean income of the poorest $20 \%$ in each of the 16 Länder was used. The coefficient therefore indicates how heterogeneous the average income of the poorest $20 \%$ is across the Länder.

Source: OECD "Income distribution", OECD Social and Welfare Statistics (database), DOI: http://dx.doi.org/10.1787/data-00654-en. 
64. When considering the scope of decentralisation indicators, three could be primarily linked to income sorting: Tax autonomy might create tax competition between sub-central governments and set incentives for individuals or firms to relocate. Decentralisation of social spending might lead to different social benefits in different regions and might also provide incentives for individuals to move. Decentralised education spending might lead to heterogeneity in school quality and provide a further incentive. The association of these three indicators with the variation of the first and fifth quintile variation across TL2 regions is shown in Figure 13.

Figure 13. Quintile income variation across TL2 regions and decentralisation indicators

Panel a) Coefficient of variation across regions of first quintile mean disposable income
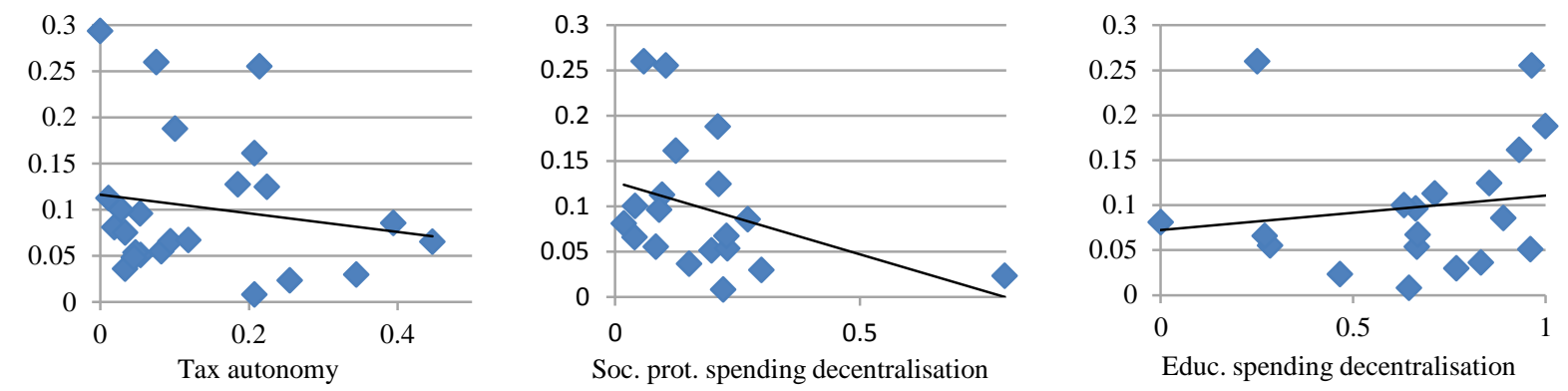

Panel b) Coefficient of variation across regions of fifth quintile mean disposable income
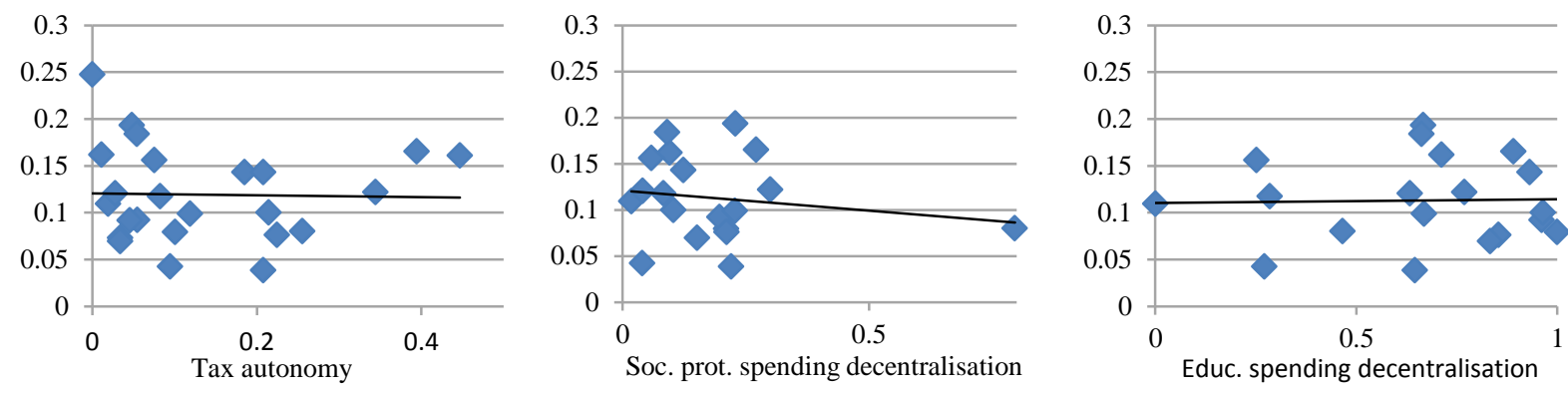

65. The association between the regional variation of first quintile average income and both tax autonomy and social protection spending decentralisation is slightly negative, while it is slightly positive for education spending decentralisation. For regional variation of fifth quintile average income, there is no clear association between the three decentralisation indicators and regional variation. This first glance suggests that decentralisation does not lead to a strong polarisation of high incomes in certain regions, but that there might be some equalising or polarising effects across regions for low incomes.

66. The results give some first indications on decentralisation and income sorting, but they are too rough to draw any firm conclusions:

- A sound empirical analysis requires more fine-grained territorial data: Income sorting is probably more pronounced between smaller territorial levels, such as municipalities, than between TL2 regions. The reason is that the degree of mobility is higher.

- It also requires controlling for other factors that might have an impact on income sorting, such as local labour and housing market characteristics and the quality of local schools. 


\section{BIBLIOGRAPHY}

Arnold, F. and H. Blöchliger (2016), "Regional GDP in OECD Countries: How Has Inequality Developed over Time?", OECD Economics Department Working Papers, No. 1329, OECD Publishing, Paris.

Bartolini, D., S. Stoßberg and H. Blöchliger (2016), "Fiscal Decentralisation and Regional Disparities:”, OECD Economics Department Working Papers, No. 1330, OECD Publishing, Paris.

Basten, C.C. et al. (2014), "Income Taxes, Sorting, and the Costs of Housing: Evidence from Municipal Boundaries in Switzerland", KOF Working Paper, No. 362.

Baum, C.F. et al. (2007), "Enhanced Routines for Instrumental Variables / Generalized Method of Moments Estimation and Testing", The Stata Journal, Vol. 7, No. 4, pp. 465-506.

Beramendi, P. (2003), "Political Institutions and Income Inequality: The Case of Decentralization", WZB Discussion Paper, No. SP II 2003-2009.

Blöchliger, H., D. Bartolini and S. Stossberg (2016), "Does Fiscal Decentralisation Foster Regional Convergence?", OECD Economic Policy Paper, No. 17, OECD Publishing, Paris.

Blöchliger, H. and J. M. Pinero Campos (2011), "Tax Competition between Sub-Central Governments", OECD Economics Department Working Papers, No. 872, OECD Publishing, Paris.

Blöchliger, H. et al. (2013), "Fiscal Federalism and its Impact on Economic Activity, Public Investment and the Performance of Educational Systems", Economics Department Working Papers, No. 1051, OECD Publishing, Paris.

Braconier, H. and J. Ruiz-Valenzuela (2014), "Gross Earning Inequalities in OECD Countries and Major Non-member Economies: Determinants and Future Scenarios", OECD Economics Department Working Papers, No. 1139, OECD Publishing, Paris.

Brenner, N. (2004), New State Spaces: Urban Governance and the Rescaling of Statehood, Oxford University Press.

Brown, C.C. and W.E. Oates (1987), “Assistance to the Poor in a Federal System”, Journal of Public Economics, Vol. 32, North Holland, pp. 307-330.

Cameron, A.C. and P.K. Trivedi (2010), Microeconometrics Using Stata, Stata Press.

Checchi, D. and C. Garcia-Peñalosa (2010), "Labour Market Institutions and the Personal Distribution of Income in the OECD”, Economica, Vol. 77, No. 307, pp. 413-450.

Davidoff, T. (2005), "Income Sorting: Measurement and Decomposition", Journal of Urban Economics, No. 58 , Issue 2.

De Hoyos, R.E. and V. Sarafidis (2006), "Testing for Cross-sectional Dependence in Panel-data Models", The Stata Journal, Vol. 6, No. 4, pp. 482-496.

Driscoll, J., and A. C. Kraay (1998). "Consistent covariance matrix estimation with spatially dependent data. Review of Economics and Statistics, Vol. 80, pp. 549-560. 
Faustino, H. C. and C. Vali (2011), "The Effects of Globalisation on OECD Income Inequality: A static and Dynamic Analysis", Working Papers Department of Economics 2011/12, ISEG - School of Economics and Management, Department of Economics, University of Lisbon.

Fredriksen, K. (2013), "Decentralisation and Economic Growth - Part 3: Decentralisation, Infrastructure Investment and Educational Performance", OECD Working Papers on Fiscal Federalism, No. 16, OECD Publishing, Paris.

Goerl, C. and M. Seiferling (2014), "Income Inequality, Fiscal Decentralization and Transfer Dependency”, IMF Working Paper, No. 64.

González Alegre, Juan (2010), "Decentralization and the Composition of Public Expenditure in Spain", Regional Studies, Vol. 44, No. 8, pp. 1067-1083.

Governatori, M. and D. Yin (2012), "Fiscal Decentralisation and Fiscal Outcomes", European Economy Economic Papers, No. 468.

Güth, W. et al. (2005), "Tax Morale and (De-)centralization: An Experimental Study", Public Choice, Vol. 125, pp. 171-188.

Hodler, R. and K. Schmidheiny (2006), "How Fiscal Decentralization Flattens Progressive Taxes", FinanzArchiv / Public Finance Analysis, Vol. 62, No. 2, pp. 281-304.

Hoechle, D. (2007), "Robust Standard Errors for Panel Regressions with Cross-sectional Dependence", The Stata Journal, Vol. 7, No. 3, pp. 281-312.

Hoeller, P. et al. (2012), "Less Income Inequality and More Growth - Are They Compatible? Part 1. Mapping Income Inequality across the OECD”, OECD Economics Department Working Papers, No. 924, OECD Publishing, Paris.

Hooghe, L. et al. (2015), A Post-functionalist Theory of Governance. Volume I: Measuring Regional Authority, Oxford University Press.

Johansson, Å. et al. (2013), "Long-Term Growth Scenarios”, OECD Economics Department Working Papers, No. 1000, OECD Publishing, Paris.

Joumard, I. et al. (2012), "Tackling Income Inequality: The Role of Taxes and Transfers", OECD Journal: Economic Studies, Vol. 2012, No. 2.

Kaufmann, D. et al. (2010), "The Worldwide Governance Indicators: Methodology and Analytical Issues", World Bank Policy Research Working Paper, No. 5430.

Keen, M. and M. Marchand (1997), "Fiscal Competition and the Pattern of Public Spending", Journal of Public Economics, Vol. 66, pp. 33-53.

Kierzenkowski, R. and I. Koske (2012), "Less Income Inequality and More Growth - Are They Compatible? Part 8. The Drivers of Labour Income Inequality - A Literature Review", OECD Economics Department Working Papers, No. 931, OECD Publishing, Paris.

Koske, I. et al. (2012), "Less Income Inequality and More Growth - Are They Compatible? Part 2. The Distribution of Labour Income", OECD Economics Department Working Papers, No. 925, OECD Publishing, Paris.

Le Galès, P. (2002), European Cities: Social Conflicts and Governance, Oxford University Press. 
Lessmann, C. (2012), "Regional Inequality and Decentralization: an Empirical Analysis", Environment and Planning A, Vol. 44, pp. 1363-1388.

McKinnon, R. (1997), "Market-preserving Fiscal Federalism in the American Monetary Union”, in M.I. Bljejer and T. Ter-Minassian (eds.), Essays in Honour of Vito Tanzi, Routledge.

Morelli, C. and P. Seaman (2007), "Devolution and Inequality: a Failure to Create a Community of Equals?", Transactions of the Institute of British Geographers, Vol. 32, pp. 523-538.

Musgrave (1959), The Theory of Public Finance: a Study in Public Economy, McGraw-Hill.

Neyapti, B. (2006), "Revenue Decentralization and Income Distribution", Economics Letters, Vol. 92(3), pp. 409-416.

Oates, W.E. (1972), Fiscal Federalism, Harcourt Brace Jovanovich.

Oates, W.E. (1999), “An Essay on Fiscal Federalism”, Journal of Economic Literature, Vol.37, pp. 1120-1149.

Oates, W.E. (2005), “Toward A Second-Generation Theory of Fiscal Federalism”, International Tax and Public Finance, Vol. 12, 349-373.

OECD (2009), How Regions Grow: Trends and Analysis, OECD Publishing, Paris

OECD (2011), Divided We Stand. Why Income Inequality Keeps Rising, OECD Publishing, Paris.

OECD (2012), “Terms of Reference: OECD Project on the Distribution of Household Incomes”, http://www.oecd.org/els/soc/IDD-ToR-Until2011.pdf

OECD (2013), Fiscal Federalism 2014: Making Decentralisation Work, OECD Publishing, Paris.

OECD (2015), Taxing Wages 2015, OECD Publishing, Paris.

Piacentini, M. (2014), "Measuring Income Inequality and Poverty at the Regional Level in OECD Countries", OECD Statistics Working Papers, 2014/03, OECD Publishing, Paris.

Prud'homme, R. (1995), “The Dangers of Decentralization”, The World Bank Observer, Vol. 10, pp. $201-220$

Qian, Y. and R. Weingast (1997), "Federalism as a Commitment to Preserving Market Incentives", Journal of Economic Perspectives, Vol. 11, No. 4, pp. 83-92.

Sacchi, A. and S. Salotti (2014), "The Effects of Fiscal Decentralization on Household Income Inequality: Some Empirical Evidence”, Spatial Economic Analysis, Vol. 9(2), pp. 202-222.

Schaltegger, C.A. et al. (2011), "Tax Competition and Income Sorting: Evidence from the Zurich Metropolitan Area”, European Journal of Political Economy, Vol. 27, No.3, pp. 455-470.

Sepulveda, C.F. and J. Martinez-Vazquez (2011), “The Consequences of Fiscal Decentralization on Poverty and Income Equality", Environment and Planning C: Government and Policy, Vol. 29, pp. 321-343.

Torgler, B. (2007), Tax Compliance and Tax Morale: A Theoretical and Empirical Analysis, Edward Elgar Publishing Limited, Cheltenham. 
Tselios, V. et al. (2012), "Income Inequality, Decentralisation, and Regional Development in Western Europe", Environment and Planning A, Vol. 44, pp. 1278-1301.

Zodrow, G. and P. Mieszkowski (1986), "Pigou, Tiebout, Property Taxation, and the Underprovision of Local Public Goods", Journal of Urban Economics, Vol. 19, No. 3. 
ECO/WKP(2016)55

APPENDIX

Table A.1. Correlation matrix of all independent variables

\begin{tabular}{|c|c|c|c|c|c|c|c|c|c|c|c|}
\hline & $\begin{array}{l}\text { Intergovernmental } \\
\text { transfers }\end{array}$ & $\begin{array}{l}\text { Individual cash } \\
\text { benefits }\end{array}$ & $\begin{array}{l}\text { Revenues from } \\
\text { personal taxes }\end{array}$ & $\begin{array}{l}\text { Kakwani index of } \\
\text { personal taxes }\end{array}$ & Unemployment & $\begin{array}{l}\text { Human } \\
\text { capital }\end{array}$ & $\begin{array}{l}\text { Employment } \\
\text { protection }\end{array}$ & $\begin{array}{l}\text { Union } \\
\text { density }\end{array}$ & Urbanisation & Trade & $\begin{array}{c}\text { Effectiveness of } \\
\text { government }\end{array}$ \\
\hline Revenue share & 0.0118 & -0.0633 & 0.3583 & -0.1383 & -0.0254 & 0.4855 & -0.3198 & 0.2309 & 0.4689 & -0.4438 & 0.3553 \\
\hline Tax share & 0.1377 & 0.0219 & 0.4126 & -0.2823 & 0.0973 & 0.3454 & -0.3083 & 0.2923 & 0.4335 & -0.4983 & 0.3668 \\
\hline Tax autonomy & 0.2055 & -0.0853 & 0.4746 & -0.3432 & 0.0428 & 0.2963 & -0.3086 & 0.4939 & 0.5264 & -0.3501 & 0.4655 \\
\hline $\begin{array}{l}\text { Education spending } \\
\text { decentralisation }\end{array}$ & 0.3233 & -0.3054 & 0.1275 & -0.3599 & 0.0169 & 0.4951 & -0.3037 & 0.005 & 0.5698 & -0.0336 & 0.2537 \\
\hline $\begin{array}{l}\text { Social protection } \\
\text { spending decentralisation }\end{array}$ & 0.5533 & 0.0434 & 0.8291 & -0.3819 & -0.3371 & 0.4744 & -0.2084 & 0.5783 & 0.5377 & -0.0386 & 0.6236 \\
\hline $\begin{array}{l}\text { Economic affairs } \\
\text { spending decentralisation }\end{array}$ & 0.2941 & -0.1538 & 0.2156 & -0.1297 & -0.199 & 0.2705 & -0.2568 & -0.2847 & 0.3172 & -0.3191 & -0.0016 \\
\hline $\begin{array}{l}\text { Income tax } \\
\text { decentralisation }\end{array}$ & 0.073 & 0.2015 & 0.4152 & -0.3769 & 0.0761 & 0.289 & 0.0068 & 0.6257 & 0.3838 & -0.3179 & 0.4911 \\
\hline $\begin{array}{l}\text { Property tax } \\
\text { decentralisation }\end{array}$ & -0.1125 & -0.2248 & 0.1004 & 0.2578 & -0.035 & 0.4412 & -0.7232 & -0.2562 & 0.2519 & -0.3909 & 0.1554 \\
\hline $\begin{array}{l}\text { Intergovernmental } \\
\text { transfers }\end{array}$ & 1 & 0.1201 & 0.6013 & -0.6261 & -0.2101 & 0.1928 & -0.1034 & 0.2906 & 0.4834 & 0.0316 & 0.3025 \\
\hline Individual cash benefits & & & 0.3542 & -0.1654 & 0.1555 & -0.034 & 0.2316 & 0.2719 & 0.0093 & -0.3526 & 0.0419 \\
\hline $\begin{array}{l}\text { Revenues from personal } \\
\text { taxes }\end{array}$ & & & 1 & -0.4768 & -0.4321 & 0.5118 & -0.2044 & 0.6208 & 0.6387 & -0.1851 & 0.6617 \\
\hline $\begin{array}{l}\text { Kakwani index of } \\
\text { personal taxes }\end{array}$ & & & & 1 & 0.0712 & -0.0578 & -0.1976 & -0.3632 & -0.3316 & 0.0974 & -0.2425 \\
\hline Unemployment & & & & & 1 & -0.4026 & 0.0287 & -0.1318 & -0.2563 & -0.0073 & -0.3548 \\
\hline Human capital & & & & & & 1 & -0.5321 & 0.1909 & 0.5503 & -0.1666 & 0.5274 \\
\hline Employment protection & & & & & & & 1 & -0.057 & -0.2528 & 0.0291 & -0.3486 \\
\hline Union density & & & & & & & & 1 & 0.4758 & 0.0221 & 0.586 \\
\hline Urbanisation & & & & & & & & & 1 & -0.2255 & 0.5694 \\
\hline Trade & & & & & & & & & & 1 & -0.0368 \\
\hline $\begin{array}{l}\text { Effectiveness of } \\
\text { government }\end{array}$ & & & & & & & & & & & 1 \\
\hline
\end{tabular}

Note: The values were calculated for the fixed effects regression sample of 20 OECD countries.

Source: OECD Fiscal Decentralisation Database, www.oecd.org/tax/federalism/oecdfiscaldecentralisationdatabase.htm; Secretariat calculations. 
Table A.2. Fixed effects percentile ratio regressions: Revenue decentralisation

\begin{tabular}{|c|c|c|c|c|c|c|c|c|c|}
\hline & \multicolumn{9}{|c|}{ Dependent variable: Percentile ratios of disposable income } \\
\hline & $\mathrm{P} 50 / \mathrm{P} 10$ & P50/P20 & P50/P30 & $\mathrm{P} 50 / \mathrm{P} 40$ & $\mathrm{P} 60 / \mathrm{P} 50$ & P70/P50 & $\mathrm{P} 80 / \mathrm{P} 50$ & P90/P50 & $\mathrm{P} 90 / \mathrm{P} 10$ \\
\hline & (1) & $(2)$ & (3) & (4) & (5) & $(6)$ & (7) & $(8)$ & (9) \\
\hline & FE & FE & FE & FE & FE & FE & FE & FE & FE \\
\hline $\begin{array}{l}\text { Revenue } \\
\text { decentralisation }\end{array}$ & $\begin{array}{l}0.648^{*} \\
(0.336)\end{array}$ & $\begin{array}{l}0.308^{*} \\
(0.168)\end{array}$ & $\begin{array}{c}0.132^{* *} \\
(0.0628)\end{array}$ & $\begin{array}{c}0.0377 \\
(0.0316)\end{array}$ & $\begin{array}{l}0.00835 \\
(0.0643)\end{array}$ & $\begin{array}{l}-0.0456 \\
(0.123)\end{array}$ & $\begin{array}{l}-0.131 \\
(0.192)\end{array}$ & $\begin{array}{l}-0.201 \\
(0.314)\end{array}$ & $\begin{array}{l}1.156^{*} \\
(0.570)\end{array}$ \\
\hline $\begin{array}{l}\text { Intergovernmental } \\
\text { transfers }\end{array}$ & $\begin{array}{l}1.488^{\star} \\
(0.778)\end{array}$ & $\begin{array}{l}0.937^{* * *} \\
(0.317)\end{array}$ & $\begin{array}{c}0.571^{\star * \star} \\
(0.143)\end{array}$ & $\begin{array}{c}0.0875 \\
(0.0597)\end{array}$ & $\begin{array}{l}0.158^{* *} \\
(0.0697)\end{array}$ & $\begin{array}{c}0.131 \\
(0.146)\end{array}$ & $\begin{array}{l}0.0773 \\
(0.341)\end{array}$ & $\begin{array}{l}0.0736 \\
(0.365)\end{array}$ & $\begin{array}{l}2.694^{*} \\
(1.358)\end{array}$ \\
\hline $\begin{array}{l}\text { Individual cash } \\
\text { benefits }\end{array}$ & $\begin{array}{c}-4.724^{* * *} \\
(0.663)\end{array}$ & $\begin{array}{l}-2.515^{\star * *} \\
(0.418)\end{array}$ & $\begin{array}{c}-1.039^{* * *} \\
(0.176)\end{array}$ & $\begin{array}{c}-0.341^{* * *} \\
(0.102)\end{array}$ & $\begin{array}{l}-0.164 \\
(0.110)\end{array}$ & $\begin{array}{l}-0.168 \\
(0.211)\end{array}$ & $\begin{array}{l}-0.164 \\
(0.384)\end{array}$ & $\begin{array}{l}-0.371 \\
(0.687)\end{array}$ & $\begin{array}{c}-9.018^{* * *} \\
(2.367)\end{array}$ \\
\hline $\begin{array}{l}\text { Revenue from } \\
\text { personal taxes }\end{array}$ & $\begin{array}{c}0.933 \\
(0.632)\end{array}$ & $\begin{array}{l}0.0345 \\
(0.395)\end{array}$ & $\begin{array}{l}0.0927 \\
(0.179)\end{array}$ & $\begin{array}{l}-0.0625 \\
(0.0747)\end{array}$ & $\begin{array}{l}-0.201 \\
(0.136)\end{array}$ & $\begin{array}{c}-0.537^{* *} \\
(0.250)\end{array}$ & $\begin{array}{l}-0.829^{* *} \\
(0.366)\end{array}$ & $\begin{array}{l}-1.108 \\
(0.684)\end{array}$ & $\begin{array}{l}-0.387 \\
(1.718)\end{array}$ \\
\hline $\begin{array}{l}\text { Kakwani index of } \\
\text { personal taxes }\end{array}$ & $\begin{array}{l}-0.427^{\star \star} \\
(0.171)\end{array}$ & $\begin{array}{l}-0.277^{\star \star \star} \\
(0.0915)\end{array}$ & $\begin{array}{l}-0.161^{*} \\
(0.0814)\end{array}$ & $\begin{array}{l}-0.0725 \\
(0.0452)\end{array}$ & $\begin{array}{l}-0.0684^{\star *} \\
(0.0277)\end{array}$ & $\begin{array}{l}-0.132^{* * *} \\
(0.0461)\end{array}$ & $\begin{array}{l}-0.193 \\
(0.127)\end{array}$ & $\begin{array}{l}-0.286 \\
(0.193)\end{array}$ & $\begin{array}{c}-1.395^{\star \star} \\
(0.520)\end{array}$ \\
\hline Unemployment rate & $\begin{array}{l}2.111^{\star \star *} \\
(0.321)\end{array}$ & $\begin{array}{c}0.631^{\star \star \star} \\
(0.120)\end{array}$ & $\begin{array}{l}0.277^{* * *} \\
(0.0872)\end{array}$ & $\begin{array}{l}0.0997^{\star} \\
(0.0533)\end{array}$ & $\begin{array}{l}0.145^{\star \star \star} \\
(0.0341)\end{array}$ & $\begin{array}{l}0.296^{\star \star \star} \\
(0.0710)\end{array}$ & $\begin{array}{l}0.426^{\star \star *} \\
(0.137)\end{array}$ & $\begin{array}{l}0.828^{\star \star} \\
(0.300)\end{array}$ & $\begin{array}{c}5.801^{\star * *} \\
(1.341)\end{array}$ \\
\hline Human capital & $\begin{array}{c}0.120 \\
(0.195)\end{array}$ & $\begin{array}{c}0.102 \\
(0.112)\end{array}$ & $\begin{array}{l}-0.0838 \\
(0.0671)\end{array}$ & $\begin{array}{l}-0.0345 \\
(0.0254)\end{array}$ & $\begin{array}{l}-0.0700 \\
(0.0446)\end{array}$ & $\begin{array}{l}-0.155^{*} \\
(0.0850)\end{array}$ & $\begin{array}{l}-0.235^{\star *} \\
(0.109)\end{array}$ & $\begin{array}{l}-0.370^{*} \\
(0.196)\end{array}$ & $\begin{array}{l}-0.817 \\
(0.646)\end{array}$ \\
\hline $\begin{array}{l}\text { Employment } \\
\text { protection }\end{array}$ & $\begin{array}{c}-0.121 \\
(0.0949)\end{array}$ & $\begin{array}{c}-0.00874 \\
(0.0478)\end{array}$ & $\begin{array}{l}-0.0402 \\
(0.0257)\end{array}$ & $\begin{array}{l}-0.00801 \\
(0.00710)\end{array}$ & $\begin{array}{c}0.00890 \\
(0.00519)\end{array}$ & $\begin{array}{c}0.0243 \\
(0.0146)\end{array}$ & $\begin{array}{l}0.0497^{\star} \\
(0.0245)\end{array}$ & $\begin{array}{l}0.119^{* * *} \\
(0.0390)\end{array}$ & $\begin{array}{c}0.00312 \\
(0.196)\end{array}$ \\
\hline Union density & $\begin{array}{l}-0.160 \\
(0.267)\end{array}$ & $\begin{array}{l}-0.0194 \\
(0.143)\end{array}$ & $\begin{array}{l}-0.0281 \\
(0.0689)\end{array}$ & $\begin{array}{c}-0.00768 \\
(0.0507)\end{array}$ & $\begin{array}{c}-0.000320 \\
(0.0376)\end{array}$ & $\begin{array}{l}-0.0325 \\
(0.0675)\end{array}$ & $\begin{array}{l}0.00992 \\
(0.0899)\end{array}$ & $\begin{array}{l}0.0215 \\
(0.188)\end{array}$ & $\begin{array}{l}0.0482 \\
(0.687)\end{array}$ \\
\hline Urbanisation & $\begin{array}{c}-1.821^{* * *} \\
(0.486)\end{array}$ & $\begin{array}{c}-1.461^{* * *} \\
(0.216)\end{array}$ & $\begin{array}{c}-0.797^{* * *} \\
(0.113)\end{array}$ & $\begin{array}{c}-0.226^{* * *} \\
(0.0546)\end{array}$ & $\begin{array}{l}-0.146^{* *} \\
(0.0616)\end{array}$ & $\begin{array}{l}-0.203 \\
(0.157)\end{array}$ & $\begin{array}{l}-0.472^{*} \\
(0.248)\end{array}$ & $\begin{array}{l}-0.826 \\
(0.555)\end{array}$ & $\begin{array}{c}-5.376^{* *} \\
(2.131)\end{array}$ \\
\hline Trade openness & $\begin{array}{l}-0.227^{* * *} \\
(0.0641)\end{array}$ & $\begin{array}{l}-0.107^{\star *} \\
(0.0451)\end{array}$ & $\begin{array}{l}-0.0681^{*} \\
(0.0332)\end{array}$ & $\begin{array}{l}-0.0192 \\
(0.0174)\end{array}$ & $\begin{array}{l}0.00443 \\
(0.0221)\end{array}$ & $\begin{array}{c}-0.0481^{* *} \\
(0.0198)\end{array}$ & $\begin{array}{c}-0.0844^{* * *} \\
(0.0193)\end{array}$ & $\begin{array}{l}-0.138^{\star *} \\
(0.0539)\end{array}$ & $\begin{array}{c}-0.728^{* * *} \\
(0.142)\end{array}$ \\
\hline $\begin{array}{l}\text { Effectiveness of } \\
\text { government }\end{array}$ & $\begin{array}{c}0.0202 \\
(0.0618)\end{array}$ & $\begin{array}{l}-0.0122 \\
(0.0289)\end{array}$ & $\begin{array}{l}-0.00552 \\
(0.0158)\end{array}$ & $\begin{array}{l}0.000728 \\
(0.00665)\end{array}$ & $\begin{array}{l}-0.00478 \\
(0.00566)\end{array}$ & $\begin{array}{c}-0.00280 \\
(0.0159)\end{array}$ & $\begin{array}{l}-0.0186 \\
(0.0239)\end{array}$ & $\begin{array}{l}-0.0586 \\
(0.0518)\end{array}$ & $\begin{array}{c}-0.0763 \\
(0.217)\end{array}$ \\
\hline Constant & $\begin{array}{c}3.760^{* * *} \\
(0.821) \\
\end{array}$ & $\begin{array}{c}2.735^{\star * *} \\
(0.382) \\
\end{array}$ & $\begin{array}{c}2.460^{* * *} \\
(0.240) \\
\end{array}$ & $\begin{array}{l}1.519^{* * *} \\
(0.107) \\
\end{array}$ & $\begin{array}{c}1.507^{* * *} \\
(0.147) \\
\end{array}$ & $\begin{array}{c}2.086^{\star * *} \\
(0.269) \\
\end{array}$ & $\begin{array}{c}2.840^{* * *} \\
(0.362) \\
\end{array}$ & $\begin{array}{c}3.962^{* * *} \\
(0.680) \\
\end{array}$ & $\begin{array}{c}12.29^{* * *} \\
(2.535) \\
\end{array}$ \\
\hline Observations & 148 & 148 & 148 & 148 & 148 & 148 & 148 & 148 & 148 \\
\hline R-squared & 0.661 & 0.627 & 0.589 & 0.401 & 0.378 & 0.420 & 0.468 & 0.445 & 0.617 \\
\hline Number of countries & 20 & 20 & 20 & 20 & 20 & 20 & 20 & 20 & 20 \\
\hline
\end{tabular}

Note: Unbalanced panel, country and time fixed effects regressions. Robust, country clustered standard errors are given in parentheses. Asterisks ${ }^{* * *}{ }^{* *}$ and $\left.{ }^{*}\right)$ indicate significance of the coefficients (at the $1 \%, 5 \%$, and $10 \%$ level, respectively). 
Table A.3. Fixed effects percentile ratio regressions: Tax decentralisation

\begin{tabular}{|c|c|c|c|c|c|c|c|c|c|}
\hline & \multicolumn{9}{|c|}{ Dependent variable: Percentile ratios of disposable income } \\
\hline & $\mathrm{P} 50 / \mathrm{P} 10$ & P50/P20 & P50/P30 & $\mathrm{P} 50 / \mathrm{P} 40$ & $\mathrm{P} 60 / \mathrm{P} 50$ & P70/P50 & P80/P50 & P90/P50 & $\mathrm{P} 90 / \mathrm{P} 10$ \\
\hline & $(1)$ & $(2)$ & (3) & $(4)$ & (5) & $(6)$ & $(7)$ & $(8)$ & (9) \\
\hline & FE & $\mathrm{FE}$ & FE & FE & $\mathrm{FE}$ & FE & FE & FE & FE \\
\hline Tax decentralisation & $\begin{array}{c}0.794^{* * *} \\
(0.186)\end{array}$ & $\begin{array}{l}0.356^{* *} \\
(0.150)\end{array}$ & $\begin{array}{c}0.151^{* *} \\
(0.0685)\end{array}$ & $\begin{array}{l}0.00168 \\
(0.0226)\end{array}$ & $\begin{array}{l}-0.0302 \\
(0.0489)\end{array}$ & $\begin{array}{l}-0.0500 \\
(0.0764)\end{array}$ & $\begin{array}{l}-0.116 \\
(0.114)\end{array}$ & $\begin{array}{l}-0.230 \\
(0.179)\end{array}$ & $\begin{array}{l}1.113^{* *} \\
(0.467)\end{array}$ \\
\hline Intergovernmental transfers & $\begin{array}{l}1.622^{\star *} \\
(0.698)\end{array}$ & $\begin{array}{c}0.994^{\star * *} \\
(0.284)\end{array}$ & $\begin{array}{c}0.595^{\star \star *} \\
(0.139)\end{array}$ & $\begin{array}{c}0.0828 \\
(0.0564)\end{array}$ & $\begin{array}{c}0.149^{*} \\
(0.0817)\end{array}$ & $\begin{array}{c}0.123 \\
(0.151)\end{array}$ & $\begin{array}{l}0.0628 \\
(0.355)\end{array}$ & $\begin{array}{l}0.0367 \\
(0.364)\end{array}$ & $\begin{array}{l}2.847^{* \star} \\
(1.305)\end{array}$ \\
\hline Individual cash benefits & $\begin{array}{c}-4.837^{\star * \star} \\
(0.638)\end{array}$ & $\begin{array}{c}-2.561^{* * *} \\
(0.415)\end{array}$ & $\begin{array}{c}-1.059^{* * *} \\
(0.185)\end{array}$ & $\begin{array}{c}-0.331^{* * *} \\
(0.101)\end{array}$ & $\begin{array}{c}-0.151 \\
(0.108)\end{array}$ & $\begin{array}{l}-0.162 \\
(0.207)\end{array}$ & $\begin{array}{l}-0.157 \\
(0.373)\end{array}$ & $\begin{array}{l}-0.342 \\
(0.661)\end{array}$ & $\begin{array}{c}-9.108^{* * *} \\
(2.484)\end{array}$ \\
\hline Revenue from personal taxes & $\begin{array}{l}1.453^{\star \star} \\
(0.611)\end{array}$ & $\begin{array}{c}0.260 \\
(0.377)\end{array}$ & $\begin{array}{c}0.188 \\
(0.183)\end{array}$ & $\begin{array}{l}-0.0762 \\
(0.0812)\end{array}$ & $\begin{array}{l}-0.234 \\
(0.141)\end{array}$ & $\begin{array}{c}-0.567^{\star \star} \\
(0.262)\end{array}$ & $\begin{array}{c}-0.890^{* *} \\
(0.400)\end{array}$ & $\begin{array}{l}-1.253^{*} \\
(0.680)\end{array}$ & $\begin{array}{c}0.239 \\
(1.996)\end{array}$ \\
\hline Kakwani index of personal taxes & $\begin{array}{l}-0.349^{*} \\
(0.173)\end{array}$ & $\begin{array}{l}-0.240^{* *} \\
(0.0914)\end{array}$ & $\begin{array}{c}-0.145 \\
(0.0840)\end{array}$ & $\begin{array}{l}-0.0677 \\
(0.0440)\end{array}$ & $\begin{array}{c}-0.0671^{\text {** }} \\
(0.0306)\end{array}$ & $\begin{array}{c}-0.138^{* * *} \\
(0.0450)\end{array}$ & $\begin{array}{l}-0.209^{*} \\
(0.115)\end{array}$ & $\begin{array}{l}-0.310^{*} \\
(0.174)\end{array}$ & $\begin{array}{c}-1.254^{* *} \\
(0.521)\end{array}$ \\
\hline Unemployment rate & $\begin{array}{c}2.126^{* * *} \\
(0.312)\end{array}$ & $\begin{array}{c}0.636^{* * *} \\
(0.117)\end{array}$ & $\begin{array}{l}0.279^{\star * \star} \\
(0.0826)\end{array}$ & $\begin{array}{c}0.0979^{*} \\
(0.0536)\end{array}$ & $\begin{array}{l}0.143^{\star * *} \\
(0.0356)\end{array}$ & $\begin{array}{l}0.296^{* * *} \\
(0.0722)\end{array}$ & $\begin{array}{l}0.426^{* * *} \\
(0.135)\end{array}$ & $\begin{array}{l}0.824^{* *} \\
(0.296)\end{array}$ & $\begin{array}{c}5.809^{* * *} \\
(1.366)\end{array}$ \\
\hline Human capital & $\begin{array}{l}0.0976 \\
(0.177)\end{array}$ & $\begin{array}{l}0.0915 \\
(0.104)\end{array}$ & $\begin{array}{l}-0.0882 \\
(0.0666)\end{array}$ & $\begin{array}{l}-0.0358 \\
(0.0258)\end{array}$ & $\begin{array}{l}-0.0702 \\
(0.0450)\end{array}$ & $\begin{array}{l}-0.154^{*} \\
(0.0839)\end{array}$ & $\begin{array}{l}-0.231^{* *} \\
(0.105)\end{array}$ & $\begin{array}{l}-0.363^{*} \\
(0.189)\end{array}$ & $\begin{array}{c}-0.856 \\
(0.669)\end{array}$ \\
\hline Employment protection & $\begin{array}{c}-0.117 \\
(0.0807)\end{array}$ & $\begin{array}{c}-0.00720 \\
(0.0414)\end{array}$ & $\begin{array}{l}-0.0395 \\
(0.0230)\end{array}$ & $\begin{array}{l}-0.00831 \\
(0.00704)\end{array}$ & $\begin{array}{c}0.00847 \\
(0.00535)\end{array}$ & $\begin{array}{c}0.0241 \\
(0.0149)\end{array}$ & $\begin{array}{c}0.0494^{*} \\
(0.0249)\end{array}$ & $\begin{array}{l}0.118^{* * *} \\
(0.0385)\end{array}$ & $\begin{array}{c}0.00630 \\
(0.185)\end{array}$ \\
\hline Union density & $\begin{array}{l}-0.151 \\
(0.243)\end{array}$ & $\begin{array}{l}-0.0135 \\
(0.130)\end{array}$ & $\begin{array}{l}-0.0255 \\
(0.0671)\end{array}$ & $\begin{array}{r}-0.00321 \\
(0.0502)\end{array}$ & $\begin{array}{l}0.00341 \\
(0.0360)\end{array}$ & $\begin{array}{l}-0.0336 \\
(0.0623)\end{array}$ & $\begin{array}{l}0.00427 \\
(0.0858)\end{array}$ & $\begin{array}{l}0.0175 \\
(0.176)\end{array}$ & $\begin{array}{l}0.0899 \\
(0.690)\end{array}$ \\
\hline Urbanisation & $\begin{array}{c}-2.005^{\star * *} \\
(0.477)\end{array}$ & $\begin{array}{c}-1.548^{* * *} \\
(0.217)\end{array}$ & $\begin{array}{c}-0.834^{* * *} \\
(0.110)\end{array}$ & $\begin{array}{c}-0.236^{* * *} \\
(0.0570)\end{array}$ & $\begin{array}{l}-0.148^{* *} \\
(0.0570)\end{array}$ & $\begin{array}{c}-0.191 \\
(0.151)\end{array}$ & $\begin{array}{l}-0.436^{*} \\
(0.247)\end{array}$ & $\begin{array}{l}-0.769 \\
(0.540)\end{array}$ & $\begin{array}{c}-5.697^{* *} \\
(2.078)\end{array}$ \\
\hline Trade openness & $\begin{array}{l}-0.234^{* * *} \\
(0.0700)\end{array}$ & $\begin{array}{l}-0.111^{* *} \\
(0.0476)\end{array}$ & $\begin{array}{l}-0.0697^{*} \\
(0.0335)\end{array}$ & $\begin{array}{l}-0.0204 \\
(0.0174)\end{array}$ & $\begin{array}{l}0.00366 \\
(0.0222)\end{array}$ & $\begin{array}{l}-0.0475^{* *} \\
(0.0218)\end{array}$ & $\begin{array}{c}-0.0822^{* * *} \\
(0.0212)\end{array}$ & $\begin{array}{l}-0.135^{* *} \\
(0.0613)\end{array}$ & $\begin{array}{c}-0.746^{* * *} \\
(0.150)\end{array}$ \\
\hline Effectiveness of government & $\begin{array}{c}0.0389 \\
(0.0589)\end{array}$ & $\begin{array}{c}-0.00379 \\
(0.0271)\end{array}$ & $\begin{array}{c}-0.00193 \\
(0.0154)\end{array}$ & $\begin{array}{l}0.000897 \\
(0.00658)\end{array}$ & $\begin{array}{l}-0.00537 \\
(0.00646)\end{array}$ & $\begin{array}{c}-0.00399 \\
(0.0166)\end{array}$ & $\begin{array}{l}-0.0215 \\
(0.0245)\end{array}$ & $\begin{array}{l}-0.0641 \\
(0.0541)\end{array}$ & $\begin{array}{c}-0.0492 \\
(0.215)\end{array}$ \\
\hline Constant & $\begin{array}{c}3.870^{* * *} \\
(0.774) \\
\end{array}$ & $\begin{array}{c}2.794^{* * *} \\
(0.387) \\
\end{array}$ & $\begin{array}{c}2.485^{\star * *} \\
(0.247) \\
\end{array}$ & $\begin{array}{c}1.539^{* * *} \\
(0.106) \\
\end{array}$ & $\begin{array}{c}1.521^{* * *} \\
(0.149) \\
\end{array}$ & $\begin{array}{c}2.076^{* * *} \\
(0.266) \\
\end{array}$ & $\begin{array}{c}2.804^{* * *} \\
(0.335) \\
\end{array}$ & $\begin{array}{c}3.923^{* * *} \\
(0.632) \\
\end{array}$ & $\begin{array}{c}12.58^{* * *} \\
(2.561) \\
\end{array}$ \\
\hline Observations & 148 & 148 & 148 & 148 & 148 & 148 & 148 & 148 & 148 \\
\hline R-squared & 0.675 & 0.635 & 0.594 & 0.398 & 0.380 & 0.421 & 0.468 & 0.447 & 0.619 \\
\hline Number of countries & 20 & 20 & 20 & 20 & 20 & 20 & 20 & 20 & 20 \\
\hline
\end{tabular}

Note: Unbalanced panel, country and time fixed effects regressions. Robust, country clustered standard errors are given in parentheses. Asterisks ( ${ }^{* \star *}$, ${ }^{*}$ and $\left.{ }^{*}\right)$ indicate significance of the coefficients (at the $1 \%, 5 \%$, and $10 \%$ level, respectively). 
Table A.4. Fixed effects percentile ratio regressions: Spending decentralisation

Dependent variable: Percentile ratios of disposable income

\begin{tabular}{|c|c|c|c|c|c|c|c|c|c|}
\hline & P50/P10 & P50/P20 & P50/P30 & P50/P40 & P60/P50 & P70/P50 & P80/P50 & P90/P50 & P90/P10 \\
\hline & $\begin{array}{l}(1) \\
\mathrm{FE} \\
\end{array}$ & $\begin{array}{l}\text { (2) } \\
\mathrm{FE} \\
\end{array}$ & $\begin{array}{l}(3) \\
\mathrm{FE} \\
\end{array}$ & $\begin{array}{l}(4) \\
\mathrm{FE} \\
\end{array}$ & $\begin{array}{l}(5) \\
\mathrm{FE} \\
\end{array}$ & $\begin{array}{l}(6) \\
\mathrm{FE} \\
\end{array}$ & $\begin{array}{l}(7) \\
\mathrm{FE}\end{array}$ & $\begin{array}{l}(8) \\
\mathrm{FE}\end{array}$ & $\begin{array}{l}(9) \\
\mathrm{FE}\end{array}$ \\
\hline $\begin{array}{l}\text { Expenditure } \\
\text { decentralisation }\end{array}$ & $\begin{array}{l}0.811^{* * *} \\
(0.199)\end{array}$ & $\begin{array}{l}0.419^{* * *} \\
(0.134)\end{array}$ & $\begin{array}{c}0.150^{*} \\
(0.0854)\end{array}$ & $\begin{array}{c}0.0512 \\
(0.0516)\end{array}$ & $\begin{array}{l}-0.0120 \\
(0.0360)\end{array}$ & $\begin{array}{l}-0.184^{* *} \\
(0.0764)\end{array}$ & $\begin{array}{l}-0.533^{* * *} \\
(0.0995)\end{array}$ & $\begin{array}{c}-0.816^{* * *} \\
(0.226)\end{array}$ & $\begin{array}{l}0.0228 \\
(0.791)\end{array}$ \\
\hline $\begin{array}{l}\text { Intergovernmental } \\
\text { transfers }\end{array}$ & $\begin{array}{l}-0.414 \\
(0.832)\end{array}$ & $\begin{array}{l}-0.0416 \\
(0.376)\end{array}$ & $\begin{array}{c}0.218 \\
(0.228)\end{array}$ & $\begin{array}{c}-0.0322 \\
(0.150)\end{array}$ & $\begin{array}{c}0.184 \\
(0.130)\end{array}$ & $\begin{array}{l}0.549^{*} \\
(0.268)\end{array}$ & $\begin{array}{c}1.286^{* * *} \\
(0.370)\end{array}$ & $\begin{array}{l}1.925^{* *} \\
(0.810)\end{array}$ & $\begin{array}{l}2.486 \\
(2.964)\end{array}$ \\
\hline $\begin{array}{l}\text { Individual cash } \\
\text { benefits }\end{array}$ & $\begin{array}{c}-3.823^{* * *} \\
(0.594)\end{array}$ & $\begin{array}{c}-2.058^{\star * *} \\
(0.422)\end{array}$ & $\begin{array}{c}-0.870^{* * *} \\
(0.184)\end{array}$ & $\begin{array}{l}-0.285^{* *} \\
(0.112)\end{array}$ & $\begin{array}{l}-0.173 \\
(0.103)\end{array}$ & $\begin{array}{l}-0.344^{*} \\
(0.194)\end{array}$ & $\begin{array}{l}-0.674^{*} \\
(0.343)\end{array}$ & $\begin{array}{l}-1.153^{*} \\
(0.652)\end{array}$ & $\begin{array}{l}8.679^{* * *} \\
(2.452)\end{array}$ \\
\hline $\begin{array}{l}\text { Revenue from } \\
\text { personal taxes }\end{array}$ & $\begin{array}{c}0.732 \\
(0.664)\end{array}$ & $\begin{array}{r}-0.0587 \\
(0.368)\end{array}$ & $\begin{array}{l}0.0505 \\
(0.175)\end{array}$ & $\begin{array}{l}-0.0739 \\
(0.0752)\end{array}$ & $\begin{array}{l}-0.205 \\
(0.142)\end{array}$ & $\begin{array}{c}-0.532^{* *} \\
(0.252)\end{array}$ & $\begin{array}{c}-0.817^{* *} \\
(0.352)\end{array}$ & $\begin{array}{l}-1.090 \\
(0.670)\end{array}$ & $\begin{array}{l}-0.857 \\
(1.899)\end{array}$ \\
\hline $\begin{array}{l}\text { Kakwani index of } \\
\text { personal taxes }\end{array}$ & $\begin{array}{c}-0.388^{\star *} \\
(0.144)\end{array}$ & $\begin{array}{l}-0.260^{\star \star *} \\
(0.0896)\end{array}$ & $\begin{array}{l}-0.152^{*} \\
(0.0824)\end{array}$ & $\begin{array}{l}-0.0705 \\
(0.0438)\end{array}$ & $\begin{array}{c}-0.0667^{* *} \\
(0.0299)\end{array}$ & $\begin{array}{l}-0.128^{* * *} \\
(0.0407)\end{array}$ & $\begin{array}{l}-0.181^{*} \\
(0.0944)\end{array}$ & $\begin{array}{l}-0.267 \\
(0.165)\end{array}$ & $\begin{array}{c}-1.249^{* *} \\
(0.496)\end{array}$ \\
\hline Unemployment rate & $\begin{array}{c}2.202^{\star * *} \\
(0.284)\end{array}$ & $\begin{array}{c}0.678^{\star * *} \\
(0.109)\end{array}$ & $\begin{array}{l}0.293^{\star \star *} \\
(0.0903)\end{array}$ & $\begin{array}{l}0.106^{*} \\
(0.0535)\end{array}$ & $\begin{array}{l}0.143^{* * *} \\
(0.0362)\end{array}$ & $\begin{array}{l}0.271^{\star \star *} \\
(0.0857)\end{array}$ & $\begin{array}{l}0.353^{*} \\
(0.174)\end{array}$ & $\begin{array}{l}0.715^{*} \\
(0.364)\end{array}$ & $\begin{array}{c}5.748^{\star \star *} \\
(1.395)\end{array}$ \\
\hline Human capital & $\begin{array}{l}0.0492 \\
(0.212)\end{array}$ & $\begin{array}{l}0.0664 \\
(0.117)\end{array}$ & $\begin{array}{c}-0.0972 \\
(0.0719)\end{array}$ & $\begin{array}{l}-0.0389 \\
(0.0257)\end{array}$ & $\begin{array}{l}-0.0695 \\
(0.0453)\end{array}$ & $\begin{array}{c}-0.142 \\
(0.0842)\end{array}$ & $\begin{array}{l}-0.198^{* *} \\
(0.0938)\end{array}$ & $\begin{array}{l}-0.314^{*} \\
(0.174)\end{array}$ & $\begin{array}{l}-0.856 \\
(0.689)\end{array}$ \\
\hline $\begin{array}{l}\text { Employment } \\
\text { protection }\end{array}$ & $\begin{array}{l}-0.0991 \\
(0.0848)\end{array}$ & $\begin{array}{l}0.00277 \\
(0.0417)\end{array}$ & $\begin{array}{l}-0.0362 \\
(0.0229)\end{array}$ & $\begin{array}{l}-0.00660 \\
(0.00722)\end{array}$ & $\begin{array}{c}0.00842 \\
(0.00569)\end{array}$ & $\begin{array}{c}0.0184 \\
(0.0145)\end{array}$ & $\begin{array}{c}0.0328 \\
(0.0200)\end{array}$ & $\begin{array}{c}0.0927^{* * *} \\
(0.0307)\end{array}$ & $\begin{array}{c}-0.00608 \\
(0.180)\end{array}$ \\
\hline Union density & $\begin{array}{l}-0.155 \\
(0.248)\end{array}$ & $\begin{array}{r}-0.0202 \\
(0.130)\end{array}$ & $\begin{array}{l}-0.0258 \\
(0.0667)\end{array}$ & $\begin{array}{l}-0.00779 \\
(0.0509)\end{array}$ & $\begin{array}{l}0.00181 \\
(0.0388)\end{array}$ & $\begin{array}{l}-0.0211 \\
(0.0613)\end{array}$ & $\begin{array}{c}0.0430 \\
(0.0851)\end{array}$ & $\begin{array}{l}0.0722 \\
(0.178)\end{array}$ & $\begin{array}{c}0.188 \\
(0.709)\end{array}$ \\
\hline Urbanisation & $\begin{array}{c}-1.506^{* *} \\
(0.559)\end{array}$ & $\begin{array}{c}-1.292^{* * *} \\
(0.278)\end{array}$ & $\begin{array}{c}-0.741^{* * *} \\
(0.141)\end{array}$ & $\begin{array}{l}-0.206^{* *} \\
(0.0732)\end{array}$ & $\begin{array}{l}-0.155^{\star *} \\
(0.0662)\end{array}$ & $\begin{array}{l}-0.301^{*} \\
(0.170)\end{array}$ & $\begin{array}{c}-0.753^{* * *} \\
(0.247)\end{array}$ & $\begin{array}{c}-1.256^{* *} \\
(0.588)\end{array}$ & $\begin{array}{c}-5.654^{* *} \\
(2.368)\end{array}$ \\
\hline Trade openness & $\begin{array}{c}-0.252^{* * *} \\
(0.0779)\end{array}$ & $\begin{array}{l}-0.119^{* *} \\
(0.0512)\end{array}$ & $\begin{array}{l}-0.0731^{*} \\
(0.0354)\end{array}$ & $\begin{array}{l}-0.0207 \\
(0.0176)\end{array}$ & $\begin{array}{l}0.00424 \\
(0.0222)\end{array}$ & $\begin{array}{l}-0.0456^{*} \\
(0.0219)\end{array}$ & $\begin{array}{c}-0.0772^{\star \star * *} \\
(0.0209)\end{array}$ & $\begin{array}{l}-0.127^{*} \\
(0.0650)\end{array}$ & $\begin{array}{c}-0.765^{\star * *} \\
(0.148)\end{array}$ \\
\hline $\begin{array}{l}\text { Effectiveness of } \\
\text { government }\end{array}$ & $\begin{array}{c}0.0206 \\
(0.0639)\end{array}$ & $\begin{array}{l}-0.0121 \\
(0.0301)\end{array}$ & $\begin{array}{c}-0.00540 \\
(0.0162)\end{array}$ & $\begin{array}{l}0.000744 \\
(0.00670)\end{array}$ & $\begin{array}{l}-0.00472 \\
(0.00587)\end{array}$ & $\begin{array}{c}-0.00254 \\
(0.0152)\end{array}$ & $\begin{array}{l}-0.0179 \\
(0.0214)\end{array}$ & $\begin{array}{l}-0.0574 \\
(0.0488)\end{array}$ & $\begin{array}{r}-0.0723 \\
(0.218)\end{array}$ \\
\hline Constant & $\begin{array}{c}3.603^{* * *} \\
(0.852)\end{array}$ & $\begin{array}{c}2.640^{* * *} \\
(0.411)\end{array}$ & $\begin{array}{c}2.437^{* * *} \\
(0.260)\end{array}$ & $\begin{array}{c}1.507^{* * *} \\
(0.125)\end{array}$ & $\begin{array}{l}1.519^{* * *} \\
(0.147)\end{array}$ & $\begin{array}{c}2.178^{* * *} \\
(0.268)\end{array}$ & $\begin{array}{c}3.105^{* * *} \\
(0.309)\end{array}$ & $\begin{array}{c}4.369^{* * *} \\
(0.625)\end{array}$ & $\begin{array}{c}12.92^{* * *} \\
(2.818)\end{array}$ \\
\hline Observations & 148 & 148 & 148 & 148 & 148 & 148 & 148 & 148 & 148 \\
\hline R-squared & 0.683 & 0.648 & 0.596 & 0.407 & 0.378 & 0.449 & 0.566 & 0.515 & 0.612 \\
\hline Number of countries & 20 & 20 & 20 & 20 & 20 & 20 & 20 & 20 & \\
\hline
\end{tabular}

Note: Unbalanced panel, country and time fixed effects regressions. Robust, country clustered standard errors are given in parentheses. Asterisks $\left({ }^{* * *},{ }^{* *}\right.$ and $\left.{ }^{*}\right)$ indicate significance of the coefficients (at the $1 \%, 5 \%$, and $10 \%$ level, respectively). 
Table A.5. Fixed effects percentile ratio regressions: Tax autonomy

\begin{tabular}{|c|c|c|c|c|c|c|c|c|c|}
\hline & \multicolumn{9}{|c|}{ Dependent variable: Percentile ratios of disposable income } \\
\hline & P50/P10 & P50/P20 & P50/P30 & P50/P40 & P60/P50 & P70/P50 & P80/P50 & P90/P50 & $\mathrm{P} 90 / \mathrm{P} 10$ \\
\hline & (1) & (2) & (3) & (4) & (5) & (6) & (7) & (8) & (9) \\
\hline & FE & FE & FE & FE & FE & FE & FE & FE & FE \\
\hline Tax autonomy & $\begin{array}{l}1.627^{* * *} \\
(0.391)\end{array}$ & $\begin{array}{c}0.858^{* * *} \\
(0.278)\end{array}$ & $\begin{array}{l}0.359^{*} \\
(0.183)\end{array}$ & $\begin{array}{c}0.109 \\
(0.0956)\end{array}$ & $\begin{array}{c}0.0382 \\
(0.0790)\end{array}$ & $\begin{array}{l}-0.101 \\
(0.154)\end{array}$ & $\begin{array}{l}-0.284 \\
(0.247)\end{array}$ & $\begin{array}{l}-0.558 \\
(0.395)\end{array}$ & $\begin{array}{l}1.993^{*} \\
(0.965)\end{array}$ \\
\hline $\begin{array}{l}\text { Intergovernmental } \\
\text { transfers }\end{array}$ & $\begin{array}{l}1.847^{* * *} \\
(0.579)\end{array}$ & $\begin{array}{l}1.090^{* * *} \\
(0.266)\end{array}$ & $\begin{array}{l}0.653^{* * *} \\
(0.122)\end{array}$ & $\begin{array}{c}0.122^{*} \\
(0.0641)\end{array}$ & $\begin{array}{l}0.189^{* *} \\
(0.0745)\end{array}$ & $\begin{array}{c}0.114 \\
(0.187)\end{array}$ & $\begin{array}{l}0.0735 \\
(0.438)\end{array}$ & $\begin{array}{c}-0.00725 \\
(0.468)\end{array}$ & $\begin{array}{c}3.244^{* * *} \\
(1.111)\end{array}$ \\
\hline $\begin{array}{l}\text { Individual cash } \\
\text { benefits }\end{array}$ & $\begin{array}{c}-5.185^{\star * *} \\
(0.834)\end{array}$ & $\begin{array}{c}-2.535^{\star * *} \\
(0.536)\end{array}$ & $\begin{array}{l}-1.04^{* \star *} \\
(0.216)\end{array}$ & $\begin{array}{c}-0.319^{* * *} \\
(0.108)\end{array}$ & $\begin{array}{l}-0.169^{*} \\
(0.0875)\end{array}$ & $\begin{array}{l}-0.259 \\
(0.194)\end{array}$ & $\begin{array}{l}-0.262 \\
(0.388)\end{array}$ & $\begin{array}{l}-0.497 \\
(0.644)\end{array}$ & $\begin{array}{c}-10.61^{* * *} \\
(2.168)\end{array}$ \\
\hline $\begin{array}{l}\text { Revenue from } \\
\text { personal taxes }\end{array}$ & $\begin{array}{l}1.608^{* *} \\
(0.582)\end{array}$ & $\begin{array}{l}0.243 \\
(0.371)\end{array}$ & $\begin{array}{l}0.0725 \\
(0.196)\end{array}$ & $\begin{array}{l}-0.0995 \\
(0.102)\end{array}$ & $\begin{array}{l}-0.107 \\
(0.123)\end{array}$ & $\begin{array}{l}-0.404 \\
(0.241)\end{array}$ & $\begin{array}{l}-0.653^{*} \\
(0.349)\end{array}$ & $\begin{array}{l}-0.945 \\
(0.622)\end{array}$ & $\begin{array}{c}1.617 \\
(1.513)\end{array}$ \\
\hline $\begin{array}{l}\text { Kakwani index of } \\
\text { personal taxes }\end{array}$ & $\begin{array}{l}-0.369^{\star} \\
(0.192)\end{array}$ & $\begin{array}{l}-0.300^{\star \star *} \\
(0.0984)\end{array}$ & $\begin{array}{c}-0.158 \\
(0.0939)\end{array}$ & $\begin{array}{l}-0.0822 \\
(0.0499)\end{array}$ & $\begin{array}{c}-0.0765^{\star *} \\
(0.0347)\end{array}$ & $\begin{array}{l}-0.140^{* *} \\
(0.0564)\end{array}$ & $\begin{array}{l}-0.226 \\
(0.136)\end{array}$ & $\begin{array}{l}-0.325 \\
(0.204)\end{array}$ & $\begin{array}{l}-1.318^{*} \\
(0.658)\end{array}$ \\
\hline Unemployment rate & $\begin{array}{c}2.101^{* * *} \\
(0.353)\end{array}$ & $\begin{array}{c}0.608^{* * *} \\
(0.149)\end{array}$ & $\begin{array}{l}0.300^{* * *} \\
(0.0892)\end{array}$ & $\begin{array}{l}0.116^{*} \\
(0.0570)\end{array}$ & $\begin{array}{l}0.120^{* * *} \\
(0.0365)\end{array}$ & $\begin{array}{l}0.279^{* * *} \\
(0.0926)\end{array}$ & $\begin{array}{l}0.410^{* *} \\
(0.178)\end{array}$ & $\begin{array}{l}0.803^{* *} \\
(0.375)\end{array}$ & $\begin{array}{r}5.762^{* * *} \\
(1.498)\end{array}$ \\
\hline Human capital & $\begin{array}{l}0.437^{*} \\
(0.237)\end{array}$ & $\begin{array}{l}0.243^{*} \\
(0.139)\end{array}$ & $\begin{array}{l}-0.0985 \\
(0.0859)\end{array}$ & $\begin{array}{l}-0.0623 \\
(0.0511)\end{array}$ & $\begin{array}{l}-0.0595 \\
(0.0425)\end{array}$ & $\begin{array}{c}-0.141 \\
(0.0943)\end{array}$ & $\begin{array}{l}-0.238 \\
(0.147)\end{array}$ & $\begin{array}{l}-0.408 \\
(0.251)\end{array}$ & $\begin{array}{l}-0.119 \\
(0.724)\end{array}$ \\
\hline $\begin{array}{l}\text { Employment } \\
\text { protection }\end{array}$ & $\begin{array}{c}-0.111 \\
(0.0794)\end{array}$ & $\begin{array}{l}0.00316 \\
(0.0393)\end{array}$ & $\begin{array}{l}-0.0374 \\
(0.0228)\end{array}$ & $\begin{array}{l}-0.00613 \\
(0.00852)\end{array}$ & $\begin{array}{l}0.0117^{* * *} \\
(0.00314)\end{array}$ & $\begin{array}{l}0.0275^{* *} \\
(0.0120)\end{array}$ & $\begin{array}{c}0.0586^{* * *} \\
(0.0178)\end{array}$ & $\begin{array}{l}0.132^{* * *} \\
(0.0295)\end{array}$ & $\begin{array}{l}0.0570 \\
(0.187)\end{array}$ \\
\hline Union density & $\begin{array}{l}-0.271 \\
(0.215)\end{array}$ & $\begin{array}{c}-0.0322 \\
(0.129)\end{array}$ & $\begin{array}{l}-0.0285 \\
(0.0812)\end{array}$ & $\begin{array}{c}-0.00641 \\
(0.0630)\end{array}$ & $\begin{array}{c}0.0354 \\
(0.0610)\end{array}$ & $\begin{array}{c}0.0255 \\
(0.0924)\end{array}$ & $\begin{array}{l}0.0971 \\
(0.119)\end{array}$ & $\begin{array}{c}0.226 \\
(0.231)\end{array}$ & $\begin{array}{c}0.214 \\
(0.674)\end{array}$ \\
\hline Urbanisation & $\begin{array}{c}-2.330^{* \star *} \\
(0.645)\end{array}$ & $\begin{array}{c}-1.755^{\star \star * *} \\
(0.268)\end{array}$ & $\begin{array}{c}-0.820^{* * *} \\
(0.143)\end{array}$ & $\begin{array}{l}-0.161^{* \star} \\
(0.0705)\end{array}$ & $\begin{array}{l}-0.120^{*} \\
(0.0675)\end{array}$ & $\begin{array}{l}-0.175 \\
(0.195)\end{array}$ & $\begin{array}{l}-0.296 \\
(0.306)\end{array}$ & $\begin{array}{l}-0.622 \\
(0.668)\end{array}$ & $\begin{array}{c}-5.963^{* *} \\
(2.633)\end{array}$ \\
\hline Trade openness & $\begin{array}{c}-0.206^{* \star *} \\
(0.0598)\end{array}$ & $\begin{array}{l}-0.123^{\star *} \\
(0.0481)\end{array}$ & $\begin{array}{l}-0.0689^{*} \\
(0.0368)\end{array}$ & $\begin{array}{l}-0.0177 \\
(0.0202)\end{array}$ & $\begin{array}{c}0.0134 \\
(0.0226)\end{array}$ & $\begin{array}{l}-0.0370^{*} \\
(0.0194)\end{array}$ & $\begin{array}{c}-0.0688^{* * *} \\
(0.0210)\end{array}$ & $\begin{array}{l}-0.122^{* *} \\
(0.0561)\end{array}$ & $\begin{array}{c}-0.642^{\star \star \star} \\
(0.110)\end{array}$ \\
\hline $\begin{array}{l}\text { Effectiveness of } \\
\text { government }\end{array}$ & $\begin{array}{c}0.0565 \\
(0.0708)\end{array}$ & $\begin{array}{c}0.0108 \\
(0.0316)\end{array}$ & $\begin{array}{l}0.00791 \\
(0.0154)\end{array}$ & $\begin{array}{c}0.00818 \\
(0.00518)\end{array}$ & $\begin{array}{l}-0.00563 \\
(0.00686)\end{array}$ & $\begin{array}{r}-0.00782 \\
(0.0193)\end{array}$ & $\begin{array}{l}-0.0219 \\
(0.0271)\end{array}$ & $\begin{array}{l}-0.0668 \\
(0.0620)\end{array}$ & $\begin{array}{l}-0.0119 \\
(0.258)\end{array}$ \\
\hline Constant & $\begin{array}{c}2.862^{* * *} \\
(0.802) \\
\end{array}$ & $\begin{array}{c}2.345^{* * *} \\
(0.409) \\
\end{array}$ & $\begin{array}{c}2.465^{\star * * *} \\
(0.282)\end{array}$ & $\begin{array}{c}1.532^{* * *} \\
(0.180)\end{array}$ & $\begin{array}{c}1.404^{* * *} \\
(0.144)\end{array}$ & $\begin{array}{c}1.970^{* * *} \\
(0.336) \\
\end{array}$ & $\begin{array}{c}2.621^{* * *} \\
(0.541)\end{array}$ & $\begin{array}{c}3.809^{* * *} \\
(0.966)\end{array}$ & $\begin{array}{c}9.731^{* * *} \\
(2.924) \\
\end{array}$ \\
\hline Observations & 138 & 138 & 138 & 138 & 138 & 138 & 138 & 138 & 138 \\
\hline R-squared & 0.714 & 0.678 & 0.617 & 0.419 & 0.348 & 0.349 & 0.392 & 0.386 & 0.611 \\
\hline Number of countries & 20 & 20 & 20 & 20 & 20 & 20 & 20 & 20 & 20 \\
\hline
\end{tabular}

Note: Unbalanced panel, country and time fixed effects regressions. Robust, country clustered standard errors are given in parentheses. Asterisks $\left(^{* \star *}\right.$, ${ }^{* *}$ and $\left.{ }^{*}\right)$ indicate significance of the coefficients (at the $1 \%, 5 \%$, and $10 \%$ level, respectively). 
Table A.6. Fixed effects percentile ratio regressions: Summary of decentralisation coefficient results

ECO/WKP(2016)55

Dependent variable: Percentile ratios of disposable income

\begin{tabular}{lcccccccc}
\hline & P50/P10 & P50/P20 & P50/P30 & P50/P40 & P60/P50 & P70/P50 & P80/P50 & P90/P50 \\
\hline & $(1)$ & $(2)$ & $(3)$ & $(4)$ & $(5)$ & $(6)$ & $(7)$ & $(8)$ \\
& FE & FE & FE & FE & FE & FE & FE & FE \\
\hline Education & 0.218 & 0.0339 & -0.0124 & -0.00579 & 0.00959 & -0.0108 & -0.0828 & -0.00528 \\
decentralisation & $(0.166)$ & $(0.0800)$ & $(0.0240)$ & $(0.0127)$ & $(0.0250)$ & $(0.0555)$ & $(0.0999)$ & $(0.199)$ \\
Social protection & 0.378 & 0.239 & 0.117 & 0.0848 & 0.0861 & -0.137 & $-0.621^{* * *}$ & $-0.478^{*}$ \\
decentralisation & $(0.360)$ & $(0.260)$ & $(0.161)$ & $(0.0905)$ & $(0.0644)$ & $(0.0918)$ & $(0.138)$ & $(0.274)$ \\
Health & $0.174^{* *}$ & $0.0600^{*}$ & 0.0216 & 0.00202 & 0.000239 & $-0.0417^{* *}$ & $-0.109^{* * *}$ & $-0.125^{* *}$ \\
decentralisation & $(0.0707)$ & $(0.0304)$ & $(0.0148)$ & $(0.00726)$ & $(0.00847)$ & $(0.0176)$ & $(0.0290)$ & $(0.0516)$ \\
Economic affairs & 0.0697 & -0.00428 & -0.00622 & -0.00111 & -0.00783 & -0.00408 & -0.0216 & $-0.130^{* *}$ \\
decentralisation & $(0.0590)$ & $(0.0394)$ & $(0.0219)$ & $(0.0120)$ & $(0.0102)$ & $(0.0224)$ & $(0.0324)$ & $(0.0559)$ \\
Income tax & $0.275^{* *}$ & $0.141^{* * *}$ & 0.0351 & -0.00449 & -0.0151 & -0.0305 & -0.0212 & -0.0342 \\
decentralisation & $(0.109)$ & $(0.0456)$ & $(0.0270)$ & $(0.0149)$ & $(0.0182)$ & $(0.0300)$ & $(0.0512)$ & $(0.103)$ \\
Property tax ratio & 1.355 & 0.157 & $0.530^{*}$ & 0.165 & $0.403^{* *}$ & $1.052^{* * *}$ & $1.511^{* * *}$ & $2.289^{* *}$ \\
& $(0.913)$ & $(0.575)$ & $(0.281)$ & $(0.163)$ & $(0.184)$ & $(0.296)$ & $(0.517)$ & $(0.995)$ \\
\hline
\end{tabular}

Note: The table shows the magnitude of beta-coefficients of selected decentralisation indicators. The regressions run to obtain the coefficients coincide with the Gini fixed effects regressions except for the dependent variable, which was replaced with different percentile ratios of disposable income. Analogously to the Gini regressions, the percentile ratio regressions were run separately for each fiscal decentralisation indicator. Robust, country clustered standard errors are given in parentheses.

Asterisks ${ }^{* * *},{ }^{* *}$ and ${ }^{*}$ ) indicate significance of the coefficients (at the $1 \%, 5 \%$, and $10 \%$ level, respectively). 
Table A.7. Gini regressions: Robustness checks

\begin{tabular}{|c|c|c|c|c|c|c|c|c|}
\hline & \multicolumn{8}{|c|}{ Dependent variable: Gini of disposable income } \\
\hline & $\begin{array}{l}(\text { II) } \\
\text { LIML } \\
\end{array}$ & $\begin{array}{l}\text { (II) } \\
\text { LIML }\end{array}$ & $\begin{array}{l}\text { (II) } \\
\text { LIML }\end{array}$ & $\begin{array}{l}\text { (II) } \\
\text { LIML }\end{array}$ & $\begin{array}{c}\text { (III) } \\
\text { Driscoll \& } \\
\text { Kraay SE } \\
\end{array}$ & $\begin{array}{c}\text { (III) } \\
\text { Driscoll \& } \\
\text { Kraay SE } \\
\end{array}$ & $\begin{array}{c}\text { (III) } \\
\text { Driscoll \& } \\
\text { Kraay SE } \\
\end{array}$ & $\begin{array}{c}\text { (III) } \\
\text { Driscoll \& } \\
\text { Kraay SE }\end{array}$ \\
\hline $\begin{array}{l}\text { Revenue } \\
\text { decentralisation }\end{array}$ & $\begin{array}{c}0.0510 \\
(0.0847)\end{array}$ & & & & $\begin{array}{l}-0.0147 \\
(0.0346)\end{array}$ & & & \\
\hline Tax decentralisation & & $\begin{array}{l}-0.0622 \\
(0.0762)\end{array}$ & & & & $\begin{array}{l}-0.0139 \\
(0.0219)\end{array}$ & & \\
\hline $\begin{array}{l}\text { Expenditure } \\
\text { decentralisation }\end{array}$ & & & $\begin{array}{l}0.0963 \\
(0.162)\end{array}$ & & & & $\begin{array}{l}-0.0426 \\
(0.0375)\end{array}$ & \\
\hline Tax autonomy & & & & $\begin{array}{l}-0.0677 \\
(0.0766)\end{array}$ & & & & $\begin{array}{c}-0.00579 \\
(0.0415)\end{array}$ \\
\hline $\begin{array}{l}\text { Intergovernmental } \\
\text { transfers }\end{array}$ & $\begin{array}{c}0.135^{\star *} \\
(0.0648)\end{array}$ & $\begin{array}{l}0.116^{*} \\
(0.0630)\end{array}$ & $\begin{array}{l}-0.0809 \\
(0.361)\end{array}$ & $\begin{array}{c}0.118^{*} \\
(0.0656)\end{array}$ & $\begin{array}{l}0.190^{* * *} \\
(0.0415)\end{array}$ & $\begin{array}{l}0.186^{* * *} \\
(0.0455)\end{array}$ & $\begin{array}{l}0.282^{* *} \\
(0.104)\end{array}$ & $\begin{array}{l}0.225^{\star * *} \\
(0.0413)\end{array}$ \\
\hline $\begin{array}{l}\text { Individual cash } \\
\text { benefits }\end{array}$ & $\begin{array}{c}-0.459^{* * *} \\
(0.119)\end{array}$ & $\begin{array}{c}-0.427^{* * *} \\
(0.108)\end{array}$ & $\begin{array}{l}-0.331 \\
(0.233)\end{array}$ & $\begin{array}{c}-0.520^{* * *} \\
(0.110)\end{array}$ & $\begin{array}{c}-0.449^{* * *} \\
(0.0495)\end{array}$ & $\begin{array}{l}-0.449^{* * *} \\
(0.0577)\end{array}$ & $\begin{array}{c}-0.497^{* * *} \\
(0.0773)\end{array}$ & $\begin{array}{l}-0.541^{* * *} \\
(0.0545)\end{array}$ \\
\hline $\begin{array}{l}\text { Revenue from } \\
\text { personal taxes }\end{array}$ & $\begin{array}{l}-0.108 \\
(0.125)\end{array}$ & $\begin{array}{l}-0.226^{*} \\
(0.136)\end{array}$ & $\begin{array}{l}-0.114 \\
(0.131)\end{array}$ & $\begin{array}{l}-0.164 \\
(0.132)\end{array}$ & $\begin{array}{l}-0.445^{\star * *} \\
(0.0767)\end{array}$ & $\begin{array}{l}-0.450^{* * *} \\
(0.0940)\end{array}$ & $\begin{array}{l}-0.447^{* * *} \\
(0.0803)\end{array}$ & $\begin{array}{l}-0.308^{* * *} \\
(0.0989)\end{array}$ \\
\hline $\begin{array}{l}\text { Kakwani index of } \\
\text { personal taxes }\end{array}$ & $\begin{array}{l}-0.0669 \\
(0.0462)\end{array}$ & $\begin{array}{l}-0.0645 \\
(0.0466)\end{array}$ & $\begin{array}{l}-0.0629 \\
(0.0486)\end{array}$ & $\begin{array}{l}-0.0442 \\
(0.0458)\end{array}$ & $\begin{array}{l}-0.0987^{* *} \\
(0.0438)\end{array}$ & $\begin{array}{l}-0.100^{* \star} \\
(0.0432)\end{array}$ & $\begin{array}{l}-0.100^{* \star} \\
(0.0439)\end{array}$ & $\begin{array}{l}-0.0786^{*} \\
(0.0450)\end{array}$ \\
\hline Unemployment rate & $\begin{array}{l}0.278^{\star * *} \\
(0.0499)\end{array}$ & $\begin{array}{l}0.265^{* * *} \\
(0.0482)\end{array}$ & $\begin{array}{l}0.288^{* * *} \\
(0.0482)\end{array}$ & $\begin{array}{l}0.294^{* * *} \\
(0.0510)\end{array}$ & $\begin{array}{l}0.226^{* * *} \\
(0.0299)\end{array}$ & $\begin{array}{l}0.227^{* * *} \\
(0.0317)\end{array}$ & $\begin{array}{l}0.222^{* * *} \\
(0.0295)\end{array}$ & $\begin{array}{l}0.269^{* * *} \\
(0.0232)\end{array}$ \\
\hline Human capital & $\begin{array}{l}-0.0192 \\
(0.0313)\end{array}$ & $\begin{array}{l}-0.0196 \\
(0.0328)\end{array}$ & $\begin{array}{l}-0.0292 \\
(0.0373)\end{array}$ & $\begin{array}{l}-0.0371 \\
(0.0443)\end{array}$ & $\begin{array}{c}0.0876^{* * *} \\
(0.0153)\end{array}$ & $\begin{array}{c}0.0869^{* * *} \\
(0.0162)\end{array}$ & $\begin{array}{l}0.0926^{* * *} \\
(0.0148)\end{array}$ & $\begin{array}{c}0.0752^{* * *} \\
(0.0253)\end{array}$ \\
\hline $\begin{array}{l}\text { Employment } \\
\text { protection }\end{array}$ & $\begin{array}{l}0.0194^{* * *} \\
(0.00661)\end{array}$ & $\begin{array}{c}0.0158^{\star *} \\
(0.00706)\end{array}$ & $\begin{array}{c}0.0222^{* *} \\
(0.00960)\end{array}$ & $\begin{array}{c}0.0143^{* *} \\
(0.00726)\end{array}$ & $\begin{array}{l}0.0189^{* * *} \\
(0.00422)\end{array}$ & $\begin{array}{l}0.0187^{* * *} \\
(0.00414)\end{array}$ & $\begin{array}{l}0.0178^{* * *} \\
(0.00438)\end{array}$ & $\begin{array}{l}0.0136^{* * *} \\
(0.00417)\end{array}$ \\
\hline Union density & $\begin{array}{l}-0.0494 \\
(0.0613)\end{array}$ & $\begin{array}{l}-0.0215 \\
(0.0645)\end{array}$ & $\begin{array}{l}-0.0642 \\
(0.0809)\end{array}$ & $\begin{array}{l}-0.0269 \\
(0.0754)\end{array}$ & $\begin{array}{l}-0.0177 \\
(0.0314)\end{array}$ & $\begin{array}{l}-0.0179 \\
(0.0336)\end{array}$ & $\begin{array}{l}-0.0142 \\
(0.0289)\end{array}$ & $\begin{array}{l}-0.0462 \\
(0.0375)\end{array}$ \\
\hline Urbanisation & $\begin{array}{l}-0.269^{* * *} \\
(0.0711)\end{array}$ & $\begin{array}{l}-0.264^{* * *} \\
(0.0716)\end{array}$ & $\begin{array}{l}-0.220^{*} \\
(0.121)\end{array}$ & $\begin{array}{l}-0.274^{\star * *} \\
(0.0759)\end{array}$ & $\begin{array}{l}-0.0853 \\
(0.0654)\end{array}$ & $\begin{array}{l}-0.0829 \\
(0.0691)\end{array}$ & $\begin{array}{l}-0.105^{\star} \\
(0.0576)\end{array}$ & $\begin{array}{c}-0.159^{*} \\
(0.0844)\end{array}$ \\
\hline Trade openness & $\begin{array}{c}-0.0373^{* * *} \\
(0.0106)\end{array}$ & $\begin{array}{c}-0.0405^{\star * *} \\
(0.0106)\end{array}$ & $\begin{array}{c}-0.0388^{* * *} \\
(0.0112)\end{array}$ & $\begin{array}{c}-0.0377^{\star * *} \\
(0.0119)\end{array}$ & $\begin{array}{c}-0.0182^{* * *} \\
(0.00535)\end{array}$ & $\begin{array}{c}-0.0182^{* \star *} \\
(0.00519)\end{array}$ & $\begin{array}{c}-0.0178^{* * *} \\
(0.00506)\end{array}$ & $\begin{array}{c}-0.0207^{\star \star \star \star} \\
(0.00565)\end{array}$ \\
\hline $\begin{array}{l}\text { Effectiveness of } \\
\text { government }\end{array}$ & $\begin{array}{l}-0.00745 \\
(0.00608)\end{array}$ & $\begin{array}{l}-0.00853 \\
(0.00623)\end{array}$ & $\begin{array}{l}-0.00801 \\
(0.00653)\end{array}$ & $\begin{array}{l}-0.00695 \\
(0.00655)\end{array}$ & $\begin{array}{l}-0.00397 \\
(0.00575)\end{array}$ & $\begin{array}{l}-0.00430 \\
(0.00572)\end{array}$ & $\begin{array}{l}-0.00326 \\
(0.00622)\end{array}$ & $\begin{array}{l}-0.00553 \\
(0.00569)\end{array}$ \\
\hline Constant & & & & & $\begin{array}{l}0.174^{* * *} \\
(0.0601) \\
\end{array}$ & $\begin{array}{c}0.175^{\star *} \\
(0.0617) \\
\end{array}$ & $\begin{array}{l}0.185^{\star * *} \\
(0.0609)\end{array}$ & $\begin{array}{l}0.277^{* * *} \\
(0.0527)\end{array}$ \\
\hline Observations & 139 & 143 & 139 & 133 & 148 & 148 & 148 & 138 \\
\hline R-squared & 0.555 & 0.559 & 0.513 & 0.558 & & & & \\
\hline Number of countries & 18 & 19 & 18 & 19 & 20 & 20 & 20 & 20 \\
\hline
\end{tabular}

Note: Standard errors are given in parentheses. Asterisks $\left(^{* * *},{ }^{* *}\right.$ and ${ }^{*}$ ) indicate significance of the coefficients (at the $1 \%, 5 \%$, and $10 \%$ level, respectively). Specification set II: Limitedinformation maximum likelihood (LIML) estimation with one and two-year lagged decentralisation variables as instruments, country and time fixed effects. Specification set III: Fixed effects regressions with Driscoll and Kraay standard errors, country fixed effects, no time fixed effects. 
Table A.8. Percentile ratio regressions: Summary table for robustness checks

\begin{tabular}{|c|c|c|c|c|c|c|}
\hline & \multicolumn{3}{|c|}{ Dependent variable: P50P10 ratio } & \multicolumn{3}{|c|}{ Dependent variable: P90P50 ratio } \\
\hline & $\begin{array}{c}\text { (I) } \\
\text { Fixed effects } \\
\text { regression }\end{array}$ & $\begin{array}{c}\text { (II) } \\
\text { LIML } \\
\text { estimation }\end{array}$ & $\begin{array}{c}\text { (III) } \\
\text { Driscoll \& } \\
\text { Kray SE'S }\end{array}$ & $\begin{array}{c}\text { (I) } \\
\text { Fixed effects } \\
\text { regression }\end{array}$ & $\begin{array}{c}\text { (II) } \\
\text { LIML } \\
\text { estimation }\end{array}$ & $\begin{array}{c}\text { (III) } \\
\text { Driscoll \& } \\
\text { Kray SE'S }\end{array}$ \\
\hline Revenue decentralisation & $\begin{array}{c}0.648^{*} \\
(0.336)\end{array}$ & $\begin{array}{c}0.918 \\
(0.601)\end{array}$ & $\begin{array}{l}0.877^{* \star *} \\
(0.304)\end{array}$ & $\begin{array}{l}-0.201 \\
(0.314)\end{array}$ & $\begin{array}{l}0.0209 \\
(0.387)\end{array}$ & $\begin{array}{l}0.0924 \\
(0.215)\end{array}$ \\
\hline Tax decentralisation & $\begin{array}{l}0.794^{\star * *} \\
(0.186)\end{array}$ & $\begin{array}{l}1.186^{* *} \\
(0.583)\end{array}$ & $\begin{array}{l}0.850^{\star * *} \\
(0.278)\end{array}$ & $\begin{array}{c}-0.230 \\
(0.179)\end{array}$ & $\begin{array}{l}-0.239 \\
(0.341)\end{array}$ & $\begin{array}{l}-0.0819 \\
(0.168)\end{array}$ \\
\hline Spending decentralisation & $\begin{array}{c}0.811^{* * *} \\
(0.199)\end{array}$ & $\begin{array}{l}1.468^{*} \\
(0.785)\end{array}$ & $\begin{array}{l}0.704^{* *} \\
(0.329)\end{array}$ & $\begin{array}{c}-0.816^{* \star *} \\
(0.226)\end{array}$ & $\begin{array}{l}-0.392 \\
(0.521)\end{array}$ & $\begin{array}{c}-0.575^{* * *} \\
(0.150)\end{array}$ \\
\hline Tax autonomy & $\begin{array}{l}1.627^{* * *} \\
(0.391)\end{array}$ & $\begin{array}{l}1.715^{* * *} \\
(0.450)\end{array}$ & $\begin{array}{l}1.930^{* * *} \\
(0.480)\end{array}$ & $\begin{array}{l}-0.558 \\
(0.395)\end{array}$ & $\begin{array}{l}-0.658 \\
(0.441)\end{array}$ & $\begin{array}{l}-0.420^{*} \\
(0.217)\end{array}$ \\
\hline
\end{tabular}

Note: Standard errors are given in parentheses. Asterisks ( ${ }^{* \star *},{ }^{* \star}$ and ${ }^{*}$ ) indicate significance of the coefficients (at the $1 \%, 5 \%$, and $10 \%$ level, respectively). Specification set II: Limitedinformation maximum likelihood (LIML) estimation with one and two-year lagged decentralisation variables as instruments, country and time fixed effects. Specification set III: Fixed effects regressions with Driscoll and Kraay standard errors, country fixed effects, no time fixed effects. 
Table A.9. Fixed effects Gini regressions with added interaction terms

\begin{tabular}{|c|c|c|c|c|c|c|c|}
\hline \multicolumn{8}{|c|}{ Dependent variable: Gini of disposable income } \\
\hline \multicolumn{8}{|c|}{ a) Interacting fiscal decentralisation indicators with the Kakwani index of tax progressivity } \\
\hline & (1a) & $(2 a)$ & $(3 a)$ & $(4 a)$ & $(5 a)$ & $(6 a)$ & \\
\hline Decentralisation indicator: & $\begin{array}{c}\text { Revenue } \\
\text { decentralisation }\end{array}$ & $\begin{array}{c}\text { Tax } \\
\text { decentralisation }\end{array}$ & $\begin{array}{c}\text { Expenditure } \\
\text { decentralisation }\end{array}$ & $\begin{array}{c}\text { Tax } \\
\text { autonomy }\end{array}$ & $\begin{array}{c}\text { Education } \\
\text { decentralisation }\end{array}$ & $\begin{array}{l}\text { Social protection } \\
\text { decentralisation }\end{array}$ & \\
\hline FD indicator & $\begin{array}{l}0.00785 \\
(0.0437)\end{array}$ & $\begin{array}{l}0.00905 \\
(0.0326)\end{array}$ & $\begin{array}{c}0.0408 \\
(0.0715)\end{array}$ & $\begin{array}{c}0.0218 \\
(0.0471)\end{array}$ & $\begin{array}{l}0.0822^{* *} \\
(0.0317)\end{array}$ & $\begin{array}{l}0.183^{* *} \\
(0.0751)\end{array}$ & \\
\hline FD indicator X Kakwani & $\begin{array}{c}-0.554^{\star *} \\
(0.255)\end{array}$ & $\begin{array}{l}-0.387^{\star *} \\
(0.184)\end{array}$ & $\begin{array}{l}-0.437^{*} \\
(0.215)\end{array}$ & $\begin{array}{c}-0.675^{\star *} \\
(0.308)\end{array}$ & $\begin{array}{c}-0.298^{* *} \\
(0.109)\end{array}$ & $\begin{array}{l}-0.792^{*} \\
(0.405)\end{array}$ & \\
\hline Kakwani & $\begin{array}{l}0.00937 \\
(0.0504)\end{array}$ & $\begin{array}{l}-0.0322 \\
(0.0414)\end{array}$ & $\begin{array}{c}0.0394 \\
(0.0650)\end{array}$ & $\begin{array}{l}-0.00883 \\
(0.0374)\end{array}$ & $\begin{array}{c}0.127 \\
(0.0843)\end{array}$ & $\begin{array}{l}-0.00595 \\
(0.0497)\end{array}$ & \\
\hline \multicolumn{8}{|c|}{ b) Interacting fiscal decentralisation indicators with regional transfer expenditure } \\
\hline & $(1 b)$ & (2b) & $(3 b)$ & $(4 b)$ & $(5 b)$ & $(6 b)$ & (7b) \\
\hline Decentralisation indicator: & $\begin{array}{c}\text { Revenue } \\
\text { decentralisation }\end{array}$ & $\begin{array}{c}\text { Tax } \\
\text { decentralisation }\end{array}$ & $\begin{array}{c}\text { Expenditure } \\
\text { decentralisation }\end{array}$ & $\begin{array}{c}\text { Fiscal } \\
\text { authority }\end{array}$ & $\begin{array}{c}\text { Tax } \\
\text { autonomy }\end{array}$ & $\begin{array}{c}\text { Education } \\
\text { decentralisation }\end{array}$ & $\begin{array}{l}\text { Social protection } \\
\text { decentralisation }\end{array}$ \\
\hline FD indicator & $\begin{array}{l}-0.00217 \\
(0.0546)\end{array}$ & $\begin{array}{c}0.0569 \\
(0.0436)\end{array}$ & $\begin{array}{l}-0.0396 \\
(0.0359)\end{array}$ & $\begin{array}{c}0.00634 \\
(0.00530)\end{array}$ & $\begin{array}{l}-0.0395 \\
(0.0678)\end{array}$ & $\begin{array}{c}0.0402 \\
(0.0275)\end{array}$ & $\begin{array}{c}0.0492 \\
(0.0492)\end{array}$ \\
\hline FD indicator $\mathrm{X}$ regional transfers & $\begin{array}{c}-1.025^{\star \star} \\
(0.439)\end{array}$ & $\begin{array}{l}-1.109^{* \star *} \\
(0.336)\end{array}$ & $\begin{array}{c}-1.587^{\star \star} \\
(0.573)\end{array}$ & $\begin{array}{l}-0.0629 \\
(0.0398)\end{array}$ & $\begin{array}{l}-0.764 \\
(0.462)\end{array}$ & $\begin{array}{l}-0.0875 \\
(0.393)\end{array}$ & $\begin{array}{l}-0.101 \\
(0.106)\end{array}$ \\
\hline Regional transfers & $\begin{array}{l}0.307^{* * *} \\
(0.0818)\end{array}$ & $\begin{array}{l}0.269^{* * *} \\
(0.0859)\end{array}$ & $\begin{array}{l}1.075^{* * *} \\
(0.351)\end{array}$ & $\begin{array}{c}0.142 \\
(0.114) \\
\end{array}$ & $\begin{array}{l}0.185^{* *} \\
(0.0809)\end{array}$ & $\begin{array}{c}0.195 \\
(0.142) \\
\end{array}$ & $\begin{array}{c}0.103 \\
(0.104) \\
\end{array}$ \\
\hline
\end{tabular}

Note: Standard errors are given in parentheses. Asterisks ${ }^{* * *}{ }^{* *}$ and ${ }^{*}$ ) indicate significance of the coefficients (at the $1 \%, 5 \%$, and $10 \%$ level, respectively). The table shows the coefficients from regressions run separately for each fiscal decentralisation indicator with the same set of redistribution and control variables as the regular Gini regressions, and an additional interaction term. 
Table A.10. Empirical literature review

\begin{tabular}{|c|c|c|c|c|c|c|c|}
\hline Study & $\begin{array}{c}\text { Country } \\
\text { coverage }\end{array}$ & $\begin{array}{l}\text { Time } \\
\text { period }\end{array}$ & Method & $\begin{array}{c}\text { Fiscal } \\
\text { decentralisation } \\
\text { indicators }\end{array}$ & $\begin{array}{l}\text { Inequality } \\
\text { measures }\end{array}$ & Control variables & Results \\
\hline \multicolumn{8}{|c|}{ Cross-country studies } \\
\hline $\begin{array}{l}\text { Beramendi (2003) } \\
\text { "Political Institutions } \\
\text { and Income } \\
\text { Inequality: The case } \\
\text { of Decentralization" }\end{array}$ & $\begin{array}{l}15 \text { OECD } \\
\text { countries }\end{array}$ & $\begin{array}{l}1980- \\
1997\end{array}$ & $\begin{array}{l}\text { Fixed effects } \\
\text { estimation, } \\
\text { random effects, } \\
\text { GLS Zellner's } \\
\text { Seemingly } \\
\text { Unrelated } \\
\text { Approach, Tobit } \\
\text { estimation }\end{array}$ & $\begin{array}{l}\text { Regional share of } \\
\text { total social } \\
\text { expenditures, } \\
\text { instrument: ethnic } \\
\text { fractionalization }\end{array}$ & $\begin{array}{l}\text { National Gini } \\
\text { coefficient for } \\
\text { disposable } \\
\text { income, } \\
\text { Between Groups } \\
\text { share of the } \\
\text { Theil Index, } \\
\text { regional } \\
\text { unemployment } \\
\text { rates }\end{array}$ & $\begin{array}{l}\text { Incumbent's ideology, union } \\
\text { density, indicator of market } \\
\text { income inequality, trade } \\
\text { openness, ethnic } \\
\text { fractionalization }\end{array}$ & $\begin{array}{l}\text { The regression results indicate that } \\
\text { decentralisation is endogenous to the income } \\
\text { distribution. } \\
\text { The between groups share of the Theil index is } \\
\text { positively related with the extent of fiscal } \\
\text { decentralization of social expenditures. In } \\
\text { conclusion, regional inequality structures } \\
\text { determine the choice of institutional design (the } \\
\text { degree of decentralisation). }\end{array}$ \\
\hline $\begin{array}{l}\text { Goerl, Seiferling } \\
\text { (2014) "Income } \\
\text { Inequality, Fiscal } \\
\text { Decentralization and } \\
\text { Transfer } \\
\text { Dependency" }\end{array}$ & $\begin{array}{l}\text { Up to } 48 \\
\text { countries in the } \\
\text { regression } \\
\text { analysis, } \\
\text { developing and } \\
\text { advanced }\end{array}$ & $\begin{array}{l}\text { From } 1980 \\
\text { onwards }\end{array}$ & $\begin{array}{l}\text { Stationary AR(1) } \\
\text { process, } \\
\text { modification of the } \\
\text { Prais-Winsten } \\
\text { transformation } \\
\text { which accounts } \\
\text { for unbalanced } \\
\text { panels }\end{array}$ & $\begin{array}{l}\text { Decentralization } \\
\text { ratios for functional } \\
\text { expenditure (social } \\
\text { protection, health, } \\
\text { education, } \\
\text { redistributive), } \\
\text { income tax } \\
\text { decentralisation } \\
\text { ratios }\end{array}$ & $\begin{array}{l}\text { National Gini } \\
\text { coefficient of } \\
\text { disposable } \\
\text { income }\end{array}$ & $\begin{array}{l}\text { Government size, quadratic } \\
\text { function of government } \\
\text { size, subnational } \\
\text { government transfer } \\
\text { dependency, log GDP per } \\
\text { capita, total government } \\
\text { expenditure in \% of GDP, } \\
\text { trade openness }\end{array}$ & $\begin{array}{l}\text { Significant relationship between the Gini } \\
\text { coefficient, aggregate redistributive and total } \\
\text { expenditure. No significance for the individual } \\
\text { redistributive expenditure categories. The effect } \\
\text { of expenditure decentralization is conditional on } \\
\text { the total government size. Transfer dependency } \\
\text { has a significant positive relationship with the } \\
\text { Gini coefficient. }\end{array}$ \\
\hline $\begin{array}{l}\text { Neyapti (2006) } \\
\text { "Revenue } \\
\text { decentralization and } \\
\text { income distribution" }\end{array}$ & $\begin{array}{l}37 \text { countries, } \\
\text { developing and } \\
\text { advanced }\end{array}$ & $\begin{array}{l}1970 \mathrm{~s}, \\
80 \mathrm{~s}, 90 \mathrm{~s}, \\
\text { in } \\
\text { averages }\end{array}$ & $\begin{array}{l}\text { Random effects } \\
\text { estimation }\end{array}$ & $\begin{array}{l}\text { Sub-central revenue } \\
\text { share, interaction of } \\
\text { revenue share with } \\
\text { governance variables } \\
\text { (corruption control, } \\
\text { rule of law, political } \\
\text { instability, } \\
\text { governmental } \\
\text { efficiency, voice and } \\
\text { accountability, } \\
\text { regulatory quality) }\end{array}$ & $\begin{array}{l}\text { Log national Gini } \\
\text { coefficient of } \\
\text { income }\end{array}$ & $\begin{array}{l}\text { Log per capita income, } \\
\text { inflation, Latin America } \\
\text { dummy }\end{array}$ & $\begin{array}{l}\text { If good governance is present, revenue } \\
\text { decentralization may reduce income inequality. } \\
\text { This effect has a greater magnitude than the } \\
\text { direct effect of good governance on the Gini } \\
\text { coefficient. }\end{array}$ \\
\hline $\begin{array}{l}\text { Sacchi, Salotti } \\
\text { (2014) "The Effects } \\
\text { of Fiscal } \\
\text { Decentralization on } \\
\text { Household Income } \\
\text { Inequality: Some } \\
\text { Empirical Evidence" }\end{array}$ & $\begin{array}{l}23 \text { OECD } \\
\text { countries }\end{array}$ & $\begin{array}{l}1971- \\
2000\end{array}$ & $\begin{array}{l}\text { Fixed effects, } \\
\text { 2SLS, FGLS with } \\
\text { fixed effects }\end{array}$ & $\begin{array}{l}\text { Three tax revenue } \\
\text { decentralization } \\
\text { indexes and four } \\
\text { expenditure } \\
\text { decentralization } \\
\text { indexes }\end{array}$ & $\begin{array}{l}\text { National Gini } \\
\text { index for gross } \\
\text { household } \\
\text { income (five- } \\
\text { year averages) }\end{array}$ & $\begin{array}{l}\text { GDP per capita, GDP per } \\
\text { capita squared, government } \\
\text { size, trade openness, } \\
\text { population growth, years of } \\
\text { primary education, left vs. } \\
\text { right orientation of ruling } \\
\text { party, political pluralism }\end{array}$ & $\begin{array}{l}\text { The decentralization of taxes, particularly of tax } \\
\text { autonomy is associated with higher income } \\
\text { inequality. Expenditure decentralization is not } \\
\text { associated with significant effects on income } \\
\text { inequality. }\end{array}$ \\
\hline
\end{tabular}


Table A.10. Empirical literature review (cont.)

\begin{tabular}{|c|c|c|c|c|c|c|c|}
\hline Study & $\begin{array}{l}\text { Country } \\
\text { coverage }\end{array}$ & $\begin{array}{l}\text { Time } \\
\text { period }\end{array}$ & Method & $\begin{array}{c}\text { Fiscal } \\
\text { decentralisation } \\
\text { indicators }\end{array}$ & $\begin{array}{l}\text { Inequality } \\
\text { measures }\end{array}$ & Control variables & Results \\
\hline \multicolumn{8}{|c|}{ Cross-country studies } \\
\hline $\begin{array}{l}\text { Sepulveda, } \\
\text { Martinez-Vazquez } \\
\text { (2011) "The } \\
\text { consequences of } \\
\text { fiscal } \\
\text { decentralization on } \\
\text { poverty and income } \\
\text { inequality" }\end{array}$ & $\begin{array}{l}34 \text { developing } \\
\text { countries } \\
\text { (poverty } \\
\text { analysis), } \\
34 \text { developing } \\
\text { and } \\
22 \text { developed } \\
\text { (inequality } \\
\text { analysis) }\end{array}$ & $\begin{array}{l}1971- \\
2000 \text { (five } \\
\text { year } \\
\text { averages) }\end{array}$ & \begin{tabular}{|l|} 
Fixed effects \\
estimation, \\
random effects \\
GLS, G2SLS
\end{tabular} & $\begin{array}{l}\text { Sub-central } \\
\text { expenditure share, } \\
\text { interaction of } \\
\text { expenditure share } \\
\text { and government size }\end{array}$ & $\begin{array}{l}\text { Poverty: national } \\
\text { head-count ratio, } \\
\text { poverty gap for a } \\
\text { poverty line of } \\
\text { USD } 1.25 \\
\text { (PPP). } \\
\text { Inequality: } \\
\text { National Gini } \\
\text { coefficient of } \\
\text { disposable } \\
\text { income (of } \\
\text { market income } \\
\text { where no other } \\
\text { data is available) }\end{array}$ & $\begin{array}{l}\text { Poverty: Log GDP per } \\
\text { capita, average schooling } \\
\text { years in total population, } \\
\text { democracy index, age } \\
\text { dependency ratio, urban } \\
\text { population share, index of } \\
\text { ethnic fractionalization. } \\
\text { Inequality: government } \\
\text { size, quadratic function of } \\
\text { log GDP per capita and log } \\
\text { GDP per capita, population } \\
\text { growth, share of urban } \\
\text { population, democracy } \\
\text { index, trade openness, } \\
\text { regional dummies, market } \\
\text { Gini dummy }\end{array}$ & $\begin{array}{l}\text { Poverty: Greater fiscal decentralization } \\
\text { increases poverty. } \\
\text { Inequality: When the government size is small, } \\
\text { higher levels of decentralisation lead to } \\
\text { increased inequality. With a government size of } \\
\text { roughly } 20 \% \text { of GDP or higher, there is a robust } \\
\text { inequality-reducing effect of fiscal } \\
\text { decentralization. }\end{array}$ \\
\hline $\begin{array}{l}\text { Tselios et al. (2012) } \\
\text { "Income inequality, } \\
\text { decentralisation, and } \\
\text { regional } \\
\text { development in } \\
\text { Western Europe" }\end{array}$ & $\begin{array}{l}13 \text { countries in } \\
\text { Western } \\
\text { Europe, } \\
102 \text { regions } \\
\text { (micro and } \\
\text { macro data) }\end{array}$ & $\begin{array}{l}1995- \\
2000\end{array}$ & $\begin{array}{l}\text { Fixed effects } \\
\text { estimation }\end{array}$ & $\begin{array}{l}\text { Sub-central } \\
\text { expenditure and } \\
\text { revenue shares, } \\
\text { regional authority } \\
\text { (composite indicators } \\
\text { for political } \\
\text { decentralisation), } \\
\text { interaction of } \\
\text { decentralization } \\
\text { variables with income } \\
\text { per capita }\end{array}$ & $\begin{array}{l}\text { Regional Theil } \\
\text { index } \\
\text { (from total net } \\
\text { personal income } \\
\text { of whole and } \\
\text { normal working } \\
\text { population) }\end{array}$ & $\begin{array}{l}\text { Trade openness, public } \\
\text { sector size, educational } \\
\text { endowment (highest level } \\
\text { completed), unemployment, } \\
\text { sectoral composition } \\
\text { (added value per capita), } \\
\text { income per capita, various } \\
\text { interaction terms }\end{array}$ & $\begin{array}{l}\text { A higher degree of fiscal decentralisation leads } \\
\text { to significantly lower income inequality within a } \\
\text { region. However, the effect becomes smaller as } \\
\text { regional income rises, so less well-off regions } \\
\text { seem to benefit most. The link between political } \\
\text { decentralisation and inequality is weaker. }\end{array}$ \\
\hline \multicolumn{8}{|c|}{ Studies at the national level } \\
\hline $\begin{array}{l}\text { Morelli, Seaman } \\
\text { (2007) "Devolution } \\
\text { and inequality: a } \\
\text { failure to create a } \\
\text { community of } \\
\text { equals?" }\end{array}$ & $\begin{array}{l}\text { UK (England, } \\
\text { Scotland, } \\
\text { Wales) }\end{array}$ & $\begin{array}{l}1991- \\
2003 \\
\text { (3-year } \\
\text { moving } \\
\text { averages) }\end{array}$ & $\begin{array}{l}\text { Regression } \\
\text { analysis (not } \\
\text { further specified) }\end{array}$ & $\begin{array}{l}\text { Dummies for } \\
\text { devolution eras } \\
\text { (Scotland, Wales) }\end{array}$ & $\begin{array}{l}\text { Regional Gini } \\
\text { coefficients of } \\
\text { household } \\
\text { equivalent } \\
\text { (McClements } \\
\text { score) adjusted } \\
\text { monthly income } \\
\text { data }\end{array}$ & $\begin{array}{l}\text { Log of average monthly } \\
\text { income, household } \\
\text { characteristics, regional } \\
\text { unemployment rate, region } \\
\text { dummies }\end{array}$ & $\begin{array}{l}\text { No noticeable impact of devolution on income } \\
\text { inequality can be detected. }\end{array}$ \\
\hline $\begin{array}{l}\text { Savitri (2012) "The } \\
\text { impacts of fiscal } \\
\text { decentralization on } \\
\text { income inequality in } \\
\text { Indonesia" }\end{array}$ & $\begin{array}{l}\text { Indonesia } \\
\text { (30 provinces) }\end{array}$ & 2003-09 & $\begin{array}{l}\text { OLS, fixed effects } \\
\text { estimation, } \\
\text { random effects }\end{array}$ & $\begin{array}{l}\text { Indonesian revenue } \\
\text { sharing funds }\end{array}$ & $\begin{array}{l}\text { Regional Gini } \\
\text { coefficient }\end{array}$ & $\begin{array}{l}\text { Population growth, years of } \\
\text { schooling, government size, } \\
\text { openness to trade, } \\
\text { investment and gross } \\
\text { regional GDP per capita }\end{array}$ & $\begin{array}{l}\text { Positive and significant relationship between } \\
\text { fiscal decentralization and income inequality in } \\
\text { Indonesia }\end{array}$ \\
\hline
\end{tabular}

